Biogeosciences Discuss., https://doi.org/10.5194/bg-2018-279

Manuscript under review for journal Biogeosciences

Discussion started: 14 June 2018

(c) Author(s) 2018. CC BY 4.0 License.

\title{
Reviews and syntheses: Processes and functional genes involved in nitrogen cycling in marine environments
}

\author{
Ramiro Ramos ${ }^{1,2}$, Silvia Pajares ${ }^{2}$ \\ ${ }^{1}$ Posgrado en Ciencias del Mar y Limnología, Universidad Nacional Autónoma de México, Mexico City, 045110, Mexico \\ 5 '2Unidad Académica de Ecología y Biodiversidad Acuática, Instituto de Ciencias del Mar y Limnología, Universidad \\ Nacional Autónoma de México, Mexico City, 045110, Mexico
}

Correspondence to: Silvia Pajares (spajares@cmarl.unam.mx)

Abstract. Nitrogen is a key element for life in the oceans. It controls primary productivity in many parts of the global ocean, consequently playing a crucial role in the uptake of atmospheric carbon dioxide. The nitrogen cycle is driven by complex biogeochemical transformations mediated by microorganisms, including classical processes such as nitrogen fixation, assimilation, nitrification, denitrification, and dissimilarity nitrate reduction to ammonia, as well as novel processes such as anaerobic ammonium oxidation, comammox and nitrite-driven anaerobic methane oxidation. The nitrogen cycle maintains the functioning of marine ecosystems and will be a crucial component in how the ocean responds to global environmental change. In this review, we summarize the current understanding of the marine microbial nitrogen cycle, its underlying

15 biochemical and enzymatic reactions, the ecology and distribution of the microorganisms involved, and the main impacts of anthropogenic activities.

\section{Introduction}

Nitrogen $(\mathrm{N})$ is a key element for life and the functioning of marine ecosystems. It plays a crucial role in marine biogeochemistry, and because of its connections to the cycles of other elements such as carbon (C) it has a strong impact on

20 Earth's climate (Gruber, 2008). $\mathrm{N}$ is scarce in the ocean, and consequently limits marine productivity in many parts of that biome (Glibert et al., 2016). Its availability also regulates the strength of the biological pump, one of the mechanisms contributing to oceanic uptake of $\mathrm{C}$ dioxide $\left(\mathrm{CO}_{2}\right)$ (Falkowski, 1997). Furthermore, one of its forms, nitrous oxide $\left(\mathrm{N}_{2} \mathrm{O}\right)$, is a powerful greenhouse gas and an ozone-depleting agent.

$\mathrm{N}$ is quite a versatile element and in the ocean is present in different oxidation states, ranging from -III in reduced forms like ammonium $\left(\mathrm{NH}_{4}{ }^{+}\right)$and organic $\mathrm{N}$ to $+\mathrm{V}$ in fully oxidized nitrate $\left(\mathrm{NO}_{3}{ }^{-}\right)$, which highlights its importance as both an electron acceptor and donor for energy metabolism in marine ecosystems (Fig. 1). Microorganisms mainly mediate the redox transformations of $\mathrm{N}$, changing the concentrations of $\mathrm{N}$ compounds in the environment (Kuypers et al., 2018). Thus, microbial communities related to marine $\mathrm{N}$ cycling have been studied extensively using both culture-dependent and independent techniques (Guerinot and Colwell, 1985; Rasigraf et al., 2017). Technological advances in nucleic acid sequencing have allowed the attainment of numerous genomic data over the past two decades, revealing enormous metabolic 
Biogeosciences Discuss., https://doi.org/10.5194/bg-2018-279

Manuscript under review for journal Biogeosciences

Discussion started: 14 June 2018

(c) Author(s) 2018. CC BY 4.0 License.

versatility within N-transforming microorganisms (Kuypers et al., 2018). Furthermore, the study of genes encoding key metabolic proteins has provided important discoveries about the biological potential of microorganisms participating in $\mathrm{N}$ cycling processes and has given deep insight into the ecological factors that determine their biogeography and activity in marine systems (Damashek and Francis, 2017; Devol, 2005; Lam and Kuypers, 2011).

5 The vast majority of $\mathrm{N}$ exists as atmospheric dinitrogen gas $\left(\mathrm{N}_{2}\right)$, which is only available to $\mathrm{N}_{2}$-fixing bacteria and archaea Thus the major sources of fixed $\mathrm{N}$ for the ocean are biological $\mathrm{N}_{2}$ fixation and atmospheric deposition, while the major sinks are denitrification and anammox. Because alterations of this balance caused by anthropogenic activity may pose significant impact on marine ecosystem health, biodiversity and climate change, the study of microbial communities involved in marine $\mathrm{N}$ cycling has gained great interest in recent years (Landolfi et al., 2017; Voss et al., 2013). To predict this impact, there is an

10 urgent need to understand the basic mechanisms that underlie microbial $\mathrm{N}$ processes in marine ecosystems.

As a contribution to this understanding, the present review provides a general survey of the microbial processes that comprise the marine $\mathrm{N}$ cycle. This includes novel processes and addresses the biochemical and enzymatic reactions involved, the genetic machinery that makes it possible, and the ecology and distribution of participating microorganisms in different marine ecosystems. We also identify several of the knowledge gaps that we still face in the study of microbial

15 marine $\mathrm{N}$ processes. We end our review with a discussion of the impacts that anthropogenic activity has on the microbially mediated mechanisms regulating the marine $\mathrm{N}$ cycle.

\section{Microbial processes in the marine $\mathbf{N}$ cycle}

The $\mathrm{N}$ cycle is driven by microbial transformations, including classical processes such as $\mathrm{N}_{2}$ fixation, assimilation, nitrification, denitrification, and dissimilarity nitrate reduction to ammonia, as well as novel processes such as anaerobic ammonium oxidation, complete ammonia oxidation (comammox) to nitrate, and nitrate/nitrite-dependent anaerobic methane oxidation, which complicates the already intricate picture of marine $\mathrm{N}$ cycling. N-converting enzymes are found in very diverse microorganisms that are globally distributed throughout marine systems, from estuarine and coastal zones to open oceans, including oxygen minimum zones (OMZs) and deep-sea environments (Fig. 2); this emphasizes their key environmental function in such systems. In addition, novel ocean microorganisms have been identified in recent years, such 25 as symbiotic heterotrophic $\mathrm{N}_{2}$-fixing cyanobacteria (Thompson et al., 2012), ammonia-oxidizing archaea (Konneke et al., 2005), and denitrifying eukaryotic foraminifera (Risgaard-Petersen et al., 2006).

\section{$2.1 \quad N_{2}$ fixation}

Marine $\mathrm{N}_{2}$ fixers are able to convert dissolved $\mathrm{N}_{2}$ gas into bioavailable $\mathrm{N}$ for planktonic production, according to the following reaction:

$30 \mathrm{~N}_{2}+8 \mathrm{H}^{+}+8 \mathrm{e}^{-}+16 \mathrm{ATP} \rightarrow 2 \mathrm{NH}_{3}+\mathrm{H}_{2}+16 \mathrm{ADP}+16 \mathrm{P}$ 
Biogeosciences Discuss., https://doi.org/10.5194/bg-2018-279

Manuscript under review for journal Biogeosciences

Discussion started: 14 June 2018

(c) Author(s) 2018. CC BY 4.0 License.

$\mathrm{N}_{2}$ is a very stable molecule, thus its fixation is an intensely energy-requiring process that only one group of microorganisms called diazotrophs is able to achieve. Marine diazotrophs mainly include cyanobacteria such as non-heterocystous filamentous cyanobacteria (e.g., Trichodesmium, Oscillatoria and Lyngbya), heterocystous filamentous cyanobacteria (e.g., Aphanizomenon and Nodularia), unicellular cyanobacteria (UCYN, such as the uncultivated Group A and Crocosphaera

5 watsonii [Group B]), and diatom symbiotic cyanobacteria (such as Richelia intracellularis). Other marine diazotrophs include heterotrophic bacteria (e.g., Klebsiella, Vibrio and Azotobacter), phototrophic bacteria (such as Chlorobium, Chromatium and Rhodospirillum), strict anaerobes (e.g., Clostridium and Desulfovibrio), iron (Fe) oxidizers (e.g., Thiobacillus) and methanogenic Euryarchaeota (Karl et al., 2002; Zehr and Paerl, 2008). These microorganisms are quite diverse but share a common feature: the nitrogenase complex, which catalyzes $\mathrm{N}_{2}$ fixation.

10 The nitrogenase complex is composed of two multisubunit metalloproteins: the molybdenum (Mo)-Fe protein (Component I) encoded in the nifD and nifK genes; and the Fe protein (Component II) encoded in the nifH gene. Alternative nitrogenases replace Mo with vanadium (V) or solely contain Fe in Component I, encoded in the vnfH and anfH genes, respectively (Zehr et al., 2003). Nitrogenase is the preferred functional biomarker in the study of diazotroph abundance and diversity because it remains highly conserved (Table S1 in the Supplement). Marine environmental nifH sequences group into four major

15 clusters designated I-IV (Jayakumar et al., 2012; Turk et al., 2011; Zehr et al., 2003), although three newly putative clusters (clusters III-x, V, and VI) have recently been identified (Dang et al., 2009b).

\subsubsection{Factors affecting $\mathrm{N}_{2}$ fixation in marine systems}

Light, oxygen $\left(\mathrm{O}_{2}\right)$, temperature, trace metals, sulfate $\left(\mathrm{SO}_{4}^{-2}\right)$, and several forms of inorganic $\mathrm{N}$ are among the main factors that affect marine diazotroph community composition. It is well known that the nitrogenase complex is inactivated by $\mathrm{O}_{2}$ and its reactive species, and diazotrophs have developed numerous protective mechanisms against this. For example, several cyanobacteria generate specialized $\mathrm{N}_{2}$-fixing cells called heterocysts that provide an almost anoxic environment. Temporal separation is another protection mechanism; most photosynthetic diazotrophs fix $\mathrm{N}_{2}$ at night when $\mathrm{O}_{2}$ is not being produced, although a number of exceptions have been identified. Zehr et al. (2008) reported the discovery of a Cyanothece-related cyanobacterium that does not possess photosystem II genes and, therefore, is able to fix $\mathrm{N}_{2}$ during both day and night Another mechanism was found in Trichodesmium, which develops diazocytes — specialized cells that share several characteristics with heterocysts - and fixes $\mathrm{N}_{2}$ during the photoperiod while simultaneously producing $\mathrm{O}_{2}$ (Berman-Frank et al., 2001b). The coupling of these processes in Trichodesmium makes light another regulating factor for $\mathrm{N}_{2}$ fixation. Capone et al. (1990) suggest that peak activity occurs around midday, hence light may be a determinant factor for $\mathrm{N}_{2}$ fixation.

$\mathrm{N}_{2}$ fixation is not intrinsically restricted by temperature and can occur near $0{ }^{\circ} \mathrm{C}$ (Stal, 2009), although temperature does seem to set the limits of where different diazotrophs can exist. The distribution of Trichodesmium, the most commonly studied diazotroph, appears to be well constrained to warmer tropical and subtropical surface waters (Breitbarth et al., 2007; Capone et al., 1997), while small diazotrophs have been mainly found in colder surface waters (Holl et al., 2007; Needoba et 
Biogeosciences Discuss., https://doi.org/10.5194/bg-2018-279

Manuscript under review for journal Biogeosciences

Discussion started: 14 June 2018

(c) Author(s) 2018. CC BY 4.0 License.

al., 2007). However, the presence of unicellular diazotrophs has also been reported in subtropical and tropical waters of the Atlantic Ocean (Foster et al., 2009; Montoya et al., 2009) and Pacific Ocean (Bonnet et al., 2009), as well as in the Arabian Sea (Mazard et al., 2004). It is important to note that temperature may be correlated with other factors that control the distribution patterns of marine diazotrophs such as $\mathrm{NO}_{3}{ }^{-}$or $\mathrm{O}_{2}$ (Sohm et al., 2011).

5 It is generally assumed that inorganic $\mathrm{N}$ is able to suppress $\mathrm{N}_{2}$ fixation in cyanobacterial diazotrophs due to the additional energetic cost associated with assimilating $\mathrm{N}_{2}$ relative to $\mathrm{NH}_{4}^{+}$or $\mathrm{NO}_{3}{ }^{-}$(Knapp, 2012), although diazotrophs can have different responses to these inorganic $\mathrm{N}$ compounds. For instance, it has been shown that $\mathrm{NO}_{3}{ }^{-}$and $\mathrm{NH}_{4}{ }^{+}$inhibit $\mathrm{N}_{2}$ fixation in Trichodesmium (Holl et al., 2005) and Nodularia (Vintila and El-Shehawy, 2007), respectively, but not in Anabaena (Ohmori and Hattori, 1974).

$10 \mathrm{Fe}$ and Mo are enzymatic cofactors, and their bioavailability directly affects $\mathrm{N}_{2}$ fixation in certain areas of the ocean (Berman-Frank et al., 2001a; Karl et al., 2002). Fe is generally depleted in surface waters of the open ocean, and the delivery of dust rich in $\mathrm{Fe}$ to the ocean may ultimately control the rate of $\mathrm{N}_{2}$ fixation on the global ocean scale (Sohm et al., 2011). For instance, Trichodesmium is abundant in the North Atlantic Ocean, in which dissolved Fe concentrations are relatively high because dust inputs are greater than in the South Atlantic Ocean, where dissolved Fe concentrations are extremely low

15 (Moore et al., 2009). In addition, $\mathrm{SO}_{4}{ }^{-2}$ indirectly inhibits $\mathrm{N}_{2}$ fixation because it reacts with Mo to form a structural analog, molybdate $\left(\mathrm{MoO}_{4}{ }^{2-}\right)$, which competes with Mo and impedes $\mathrm{N}_{2}$ fixation (Karl et al., 2002; Zehr and Paerl, 2008).

\subsubsection{Distribution of diazotrophs in marine environments}

$\mathrm{N}_{2}$ fixation seems to be an important process, not only in tropical surface waters (Capone et al., 2005) but also in hypoxic waters (Hamersley et al., 2011), deep sea (Dekas et al., 2009), hydrothermal vents (Mehta and Baross, 2006) and coral reefs (Lema et al., 2012), as well as in estuaries and nutrient-rich coastal upwelling regions (Wen et al., 2017). The main findings concerning the distribution of diazotrophs in several marine environments are summarized below.

Open oceans

Due to the energetic demand that it poses, $\mathrm{N}_{2}$-fixation is a clear advantage in extremely oligotrophic environments such as ocean gyres, in which reactive N (Nr) is scarce (Capone et al., 2005; Karl et al., 2002). The abundance and distribution of the nifH gene have been studied in different areas of the open ocean; much of this research has focused on Trichodesmium, which has a cosmopolitan distribution throughout the nutrient-poor tropical and subtropical seas where it often forms massive surface blooms (Capone et al., 2005). Although the three main diazotroph types (Trichodesmium analogs, UCYN, and diatom diazotroph associations) seem to coexist in the ocean, Trichodesmium dominates in the North and Tropical Indian oceans, and diatom diazotroph associations are widely distributed through the warm oligotrophic ocean, with the largest densities in the Amazon River plume (Monteiro et al., 2010; Sohm et al., 2011). 
Biogeosciences Discuss., https://doi.org/10.5194/bg-2018-279

Manuscript under review for journal Biogeosciences

Discussion started: 14 June 2018

(c) Author(s) 2018. CC BY 4.0 License.

The dominance of Trichodesmium in the warmer waters of the Tropical and Subtropical Atlantic Ocean seems to be due to low concentrations of inorganic $\mathrm{N}$ forms (Goebel et al., 2010; Langlois et al., 2005), while its dominance in the Northern Atlantic Ocean seems to be due to the higher and lower concentrations of dissolved $\mathrm{Fe}$ and inorganic $\mathrm{P}$, respectively (Langlois et al., 2008; Moore et al., 2009). The most abundant diazotrophs in the Eastern Equatorial Atlantic appear to be

5 Trichodesmium and UCYN Group A, and their distributions are controlled by riverine inputs and upwelling (Foster et al., 2009). In the Pacific Ocean, UCYN groups are mainly restricted to the well-lit, nutrient-poor waters of the North Pacific Subtropical Gyre (Church et al., 2008; Gradoville et al., 2017; Needoba et al., 2007), while heterotrophs (mainly Alpha- and Betaproteobacteria) dominate the diazotrophic community in the Eastern South Pacific and Pacific Northwest coastal upwelling systems (Gradoville et al., 2017). In general, diazotrophs are in lower abundances in the South Pacific Ocean, and temperature and depth seem to control the distribution of the two UCYN groups: Crocosphaera dominates in warmer surface waters, while Group A does so in cooler waters (Moisander et al., 2010). In addition, high abundances of Group A can be found at higher latitudes and deeper waters than Trichodesmium in the South Pacific Ocean (Moisander et al., 2010). $\mathrm{N}_{2}$ fixation in the Indian Ocean is poorly understood and seems to be mainly performed by heterotrophic bacteria (Shiozaki et al., 2014), except in the Arabian Sea where persistent Trichodesmium blooms occur (Capone et al., 1998).

15

Estuaries and coastal zones

Little is known about the distribution and activity of diazotrophs in estuaries and coastal regions. $\mathrm{N}_{2}$ fixation in these systems is affected by high nutrient inputs from land, so it is assumed to be unimportant (Howarth et al., 1988). However, recent studies suggest that $\mathrm{N}_{2}$ fixation may be an important source of $\mathrm{Nr}$ in a number of estuaries and nutrient-repleted coastal upwelling regions (Fulweiler et al., 2007; Mulholland et al., 2012; Wen et al., 2017). Also, studies of diversity, abundance, and expression of the nifH gene have suggested complicated relationships between environmental drivers and diazotroph distribution in these ecosystems (Moisander et al., 2007; Severin et al., 2015; Short et al., 2004). In the Baltic Sea, for instance, planktonic heterotrophic diazotrophs were found to be common in a eutrophic estuary while cyanobacterial diazotrophs were more abundant in a lower-nutrient estuary (Bentzon-Tilia et al., 2015). In the coastal waters of the MidAtlantic continental shelf, UCYN-A was the most abundant diazotroph (Mulholland et al., 2012), while diatom symbiotic cyanobacteria dominated over the other diazotrophic groups in the upwelling regions of the Taiwan Strait where high diazotrophic activity was present (Wen et al., 2017).

Deep-sea environments

30 Mehta et al. (2003) provided the first evidence of nifH genes, mostly belonging to clusters II and III, in deep-sea hydrothermal vent fluid. A few years later Mehta and Baross (2006) isolated a methanogenic archaeon from said environment that was able to fix $\mathrm{N}_{2}$ at $92^{\circ} \mathrm{C}$. Potential $\mathrm{N}_{2}$ fixation by methanogenic archaea was also found in seep sediments from the Kumano Basin in Japan (Miyazaki et al., 2009). Cao et al. (2015) compared the abundance and diversity of nifH sequences in hydrothermal vents from four middle ocean ridges; being cluster I, comprised by proteobacterial and 
Biogeosciences Discuss., https://doi.org/10.5194/bg-2018-279

Manuscript under review for journal Biogeosciences

Discussion started: 14 June 2018

(c) Author(s) 2018. CC BY 4.0 License.

cyanobacterial nifH sequences, the most dominant group. Wu et al. (2014) found that nifH sequences belonging to proteobacterial clusters I and III dominate $\mathrm{N}_{2}$ fixation in the sediments from a deep-sea hydrothermal vent in the Southwest Indian Ridge. In addition, nifH sequences retrieved from methane seep sediments in the Okhotsk Sea were placed into three new putative clusters (III-x, V and VI). Sequences from cluster V were unique to these sediments, and sequences from

5 cluster III-x are unique to the deep-sea methane seep environments studied to date (Dang et al., 2009b).

An intriguing microbial consortium was isolated from a methane cold seep in Eel River Basin, California (Dekas et al., 2009). The consortium, composed of an anaerobic methanotrophic archaeon (ANME) and a sulfate-reducing bacterium (SRB), mediated both sulfate-dependent anaerobic methane oxidation (SDAMO) and $\mathrm{N}_{2}$ fixation. This is interesting from an energetic point of view, given that $\mathrm{N}_{2}$ fixation is a very energy-demanding process and SDAMO is one of the least energetically productive metabolisms (Strous and Jetten, 2004). In addition, a study conducted in methane seep sediments in Costa Rica showed that the distribution of $\mathrm{N}_{2}$ fixation by this consortium is heterogeneous and is likely influenced by chemical gradients (Dekas et al., 2014).

Coral reefs

15 Corals are found in $\mathrm{N}$-depleted tropical and subtropical coastal waters; thus, $\mathrm{N}_{2}$ fixation should play an important role in the ecosystems there, providing an additional source of $\mathrm{N}$ for symbiotic dinoflagellates and thus improving the productivity of those systems (Lema et al., 2012). In fact, several studies have found evidence of $\mathrm{N}_{2}$-fixing symbionts in coral reefs, heterotrophic Proteobacteria being the dominant diazotrophs in different types of coral holobionts (Lema et al., 2012; Lema et al., 2014; Olson, 2009; Olson and Lesser, 2013). Furthermore, diazotrophic communities seem to differ among the trophic functional groups of coral, suggesting that the ecological importance of $\mathrm{N}_{2}$-fixing symbionts may be determined by the trophic functional group of the host. For instance, Pogoreutz et al. (2017) found that autotrophic Pocilloporidae exhibited nifH copies and gene expression 100 times higher than those in heterotrophic Fungiidae, suggesting that $\mathrm{N}_{2}$ fixation compensates for the low heterotrophic $\mathrm{N}$ uptake in autotrophic corals.

\subsection{Nitrification}

25 Nitrification involves three types of microorganisms: 1) those who oxide ammonia $\left(\mathrm{NH}_{3}\right)$ to nitrite $\left(\mathrm{NO}_{2}{ }^{-}\right)($nitritation$\left.), 2\right)$ those who oxide $\mathrm{NO}_{2}^{-}$to $\mathrm{NO}_{3}^{-}$(nitratation), and 3) those who oxide $\mathrm{NH}_{4}^{+}$directly to $\mathrm{NO}_{3}^{-}$(comammox, complete ammonium oxidation), which will be addressed in the next section.

(1) $\mathrm{NH}_{3}+\mathrm{O}_{2} \rightarrow \mathrm{NO}_{2}^{-}+3 \mathrm{H}^{+}+2 \mathrm{e}^{-}$

(2) $2 \mathrm{NO}_{2}^{-}+\mathrm{O}_{2} \rightarrow 2 \mathrm{NO}_{3}^{-}$

(3) $\mathrm{NH}_{4}^{+}+2 \mathrm{O}_{2} \rightarrow \mathrm{NO}_{3}^{-}+\mathrm{H}_{2} \mathrm{O}+2 \mathrm{H}^{+}$

Reaction (1) is carried out by ammonia oxidizers, which are chemolithotrophs classified in two groups: ammonia-oxidizing bacteria (AOB) belonging to a few genera within the Betaproteobacteria (Nitrosomonas and Nitrosospira) and 
Biogeosciences Discuss., https://doi.org/10.5194/bg-2018-279

Manuscript under review for journal Biogeosciences

Discussion started: 14 June 2018

(c) Author(s) 2018. CC BY 4.0 License.

Gammaproteobacteria (Nitrosococcus) classes (Purkhold et al., 2000), and ammonia-oxidizing archaea (AOA) belonging to the Thaumarchaeota phylum, such as Nitrosopumilus maritimus (Konneke et al., 2005). The discovery of AOA solved the long-standing mystery of the apparently rare ammonia oxidizers in the ocean (Wuchter et al., 2006). This reaction is a twostep process: the first and rate-limiting step is the conversion of $\mathrm{NH}_{3}$ to hydroxylamine $\left(\mathrm{NH}_{2} \mathrm{OH}\right)$ catalyzed by the ammonia

5 monooxygenase (AMO). The second step was once believed to be the conversion of $\mathrm{NH}_{2} \mathrm{OH}$ to $\mathrm{NO}_{2}{ }^{-}$by the hydroxylamine oxidoreductase (HAO), but recent studies indicate that $\mathrm{NH}_{2} \mathrm{OH}$ is first converted to nitric oxide (NO), then $\mathrm{NO}$ is oxidized to $\mathrm{NO}_{2}{ }^{-}$under aerobic conditions (Caranto and Lancaster, 2017). This is interesting since Ward (2008) reported the production of $\mathrm{NO}, \mathrm{NO}_{2}$ and even $\mathrm{N}_{2}$ from $\mathrm{NH}_{4}^{+}$in marine environments, which is enhanced in suboxic conditions.

The AMO enzyme is composed of three subunits: AmoA, AmoB and AmoC. The amoA gene, coding for the AmoA, has

10 been widely used as a molecular marker for studying ammonia oxidizers in the environment (Rotthauwe \& Witzel, 1997) (Table S2 in the Supplement). Several considerations must be taken for the analysis of amoA-containing microorganisms: AOB belonging to Betaproteobacteria usually possess more than one copy of the gene, while Gammaproteobacteria only possess one copy. Additionally, some primers used in the amplification of this gene can also amplify the $p m o A$ genes from methane-oxidizing bacteria, since both genes are phylogenetically related (Norton et al., 2002). The HAO enzyme is a

15 homotrimer and is encoded in the hao gene, present only in AOB with multiple copies (Arp et al., 2007). The hao gene has been little-used as a molecular marker of AOB in marine systems (Lüke et al., 2016; Rasigraf et al., 2017).

Reaction (2) is simpler, since it only requires the transference of two electrons and does not produce intermediaries. It is catalyzed by the nitrite oxidoreductase (NXR), which is present in nitrite-oxidizing bacteria (NOB) such as Chloroflexi, Nitrospirae, Nitrospinae and several classes of Proteobacteria (Ward, 2008). Three subunits comprise the NXR enzyme: NxrA, NxrB and NxrC. The gene encoding NrxA has been used as a marker for studying NOB in a number of marine environments (Lüke et al., 2016; Rani et al., 2017; Rasigraf et al., 2017) (Table S2 in the Supplement).

\subsubsection{Factors affecting nitrification in marine systems}

Oxygen, light, $\mathrm{pH}$, salinity, $\mathrm{NH}_{4}{ }^{+}$and $\mathrm{NO}_{2}{ }^{-}$are among the main factors controlling nitrification. Nitrifiers require oxygen for metabolism, but they seem to do well in microaerophilic conditions. It has been demonstrated that low $\mathrm{O}_{2}$ and $\mathrm{NO}_{2}{ }^{-}$ concentrations are correlated with the abundance of AOA in a number of marine environments (Cao et al., 2012; De Corte et al., 2009; Urakawa et al., 2014). Nitrifying organisms avoid light because it affects the cytochromes involved in electron transport; thus, the highest rates of ammonia oxidation often occur just below the sunlit ocean surface (Yool et al., 2007). Additionally, amoA transcripts have been reported to be more abundant in the surface of the Arctic Ocean during the darkest winter month as well as in the halocline, where light levels are perpetually lower (Pedneault et al., 2014). Nitrification seems to be controlled by $\mathrm{NH}_{4}{ }^{+}$limitation and, just like any other process involving hydrogen ions $\left(\mathrm{H}^{+}\right)$, is affected by $\mathrm{pH}(\mathrm{Ward}$, 2008, 2013). Temperature does not affect nitrification directly, but can affect community composition in some environments. For example, the composition and abundance of AOA communities in the San Francisco Bay estuary seem to be highly 
Biogeosciences Discuss., https://doi.org/10.5194/bg-2018-279

Manuscript under review for journal Biogeosciences

Discussion started: 14 June 2018

(c) Author(s) 2018. CC BY 4.0 License.

correlated with temperature (Mosier and Francis, 2008), while marine AOA seem unaffected by it (Horak et al., 2013). Temperature also seems to be an important factor influencing the distribution and diversity of AOA and AOB in sponge associations (Cardoso et al., 2013). Other factors affecting marine nitrifier communities are site-specific. For example, in deep-sea hydrothermal vents, total $\mathrm{N}$ and $\mathrm{S}$ seem to control the distribution of ammonia oxidizers (Xu et al., 2014).

5 Moreover, salinity is an important factor driving amoA gene diversity in water columns and sediments from estuaries (e.g., Beman and Francis 2006; Bernhard et al., 2005; Bernhard et al., 2010; Bouskill et al., 2011; Dang et al., 2008; Francis et al., 2003; Mosier and Francis, 2008; Smith et al., 2015b).

\subsubsection{Distribution of nitrifier communities in marine environments}

\section{Open oceans}

10 The distribution of nitrifier communities in the open ocean has been widely studied. In this environment, AOA seem to be present throughout the water column and outnumber AOB (Beman et al., 2012; Mincer et al., 2007), which sometimes go undetected (Mincer et al., 2007; Molina et al., 2010). Community distribution changes depending on the area of the ocean. In the Eastern Tropical North Pacific and Gulf of California, AOA are active in the euphotic layer and AOB are confined to higher depths (Beman et al., 2012), while in the North Pacific Subtropical Gyre AOA are predominantly distributed below the euphotic zone (Mincer et al., 2007). Along the Peruvian coast, both AOA and AOB exhibit a strong amoA expression in the upper OMZ (Lam et al., 2009). In the central Pacific Ocean, abundance of the AOA amoA gene increases with depth and shows peak abundances in the dimly lit waters of the mesopelagic zone (Church et al., 2010). Moreover, AOA form vertical and latitudinal gradients throughout the North Atlantic, where their abundance and diversity gradually decrease in the mesoand bathypelagic waters from the north towards the equator (Agogué et al., 2008). Shiozaki et al. (2016) found that $\mathrm{NH}_{4}^{+}$ oxidation in the euphotic zone occurred at almost all the stations along a transect from the equatorial Pacific to the Arctic Ocean and was mainly performed by AOA. Studies on nitrifiers in other waters include the Arabian Sea OMZ, where AOA and anammox bacteria have different vertical distributions and occupy different niches (Pitcher et al., 2011a), and the Mediterranean Sea, where the abundance of AOA decreases with depth and is stratified into surface and deep-sea communities (De Corte et al., 2009).

25 It has also been found that there are two distinct ecotypes of AOA (Francis et al., 2005; Luo et al., 2014). The water column group A (WCA) or "shallow" ecotype is typically most abundant in the epipelagic and upper mesopelagic (Beman et al., 2008), while the water column group B (WCB) or "deep" ecotype dominates the meso- and bathypelagic, where the $\mathrm{NH}_{4}^{+}$ flux is very low (Sintes et al., 2013). This distribution of AOA ecotypes is consistent with other reports in the Northeast Pacific (Smith et al., 2016) and the California Current (Santoro et al., 2010). Moreover, in the Eastern South Pacific, WCA is

30 associated with higher $\mathrm{O}_{2}$ and $\mathrm{NH}_{4}^{+}$concentrations, while WCB is associated to permanent OMZ and $\mathrm{NH}_{4}^{+}$-depleted waters (Molina et al., 2010). 
Biogeosciences Discuss., https://doi.org/10.5194/bg-2018-279

Manuscript under review for journal Biogeosciences

Discussion started: 14 June 2018

(c) Author(s) 2018. CC BY 4.0 License.

Nitrifiers have also been studied in symbiosis with marine organisms. Nitrospira seems to be the major driver of nitrification in different types of sponges (Mohamed et al., 2010; Radax et al., 2012), while Zhang et al. (2014a) found that Nitrosopumilus-related AOA were the active ammonia oxidizers in four species of sponges. In addition, Thaumarchaeota plays an important nitrification role within the tissue of colonial ascidians (Martínez-García et al., 2008).

5

Estuaries and coastal environments

In general, the AOA community is more diverse than that of AOB in estuary sediments (Beman and Francis, 2006; Caffrey et al., 2007; Jin et al., 2011; Zhang et al., 2014b; Zheng et al., 2014). However, the dominance of one group over the other is unclear. In some estuaries, AOA form the most abundant nitrifier community (e.g., Caffrey et al., 2007; Jin et al., 2011;

10 Zhang et al., 2014b), while in others they are less abundant than or equal to AOB (e.g., Mosier and Francis, 2008; Li et al., 2015; Reyes et al., 2017; Zheng et al., 2014). The salinity gradient seems to be the main factor controlling the diversity and distribution of nitrifier communities in estuaries. AOA belonging to "sediment" and "marine" clades (Nitrosopumilus-like sequences) are more abundant in the mouth, whereas AOA belonging to the "low salinity" (Nitrosoarchaeum-like sequences) and "soil" (group 1.1b) clades are more abundant in the head of many estuaries (Beman and Francis, 2006;

15 Bernhard et al., 2010; Dang et al., 2008; Francis et al., 2003; Mosier and Francis, 2008; Smith et al., 2015b). Similarly, AOB sequences belonging to the Nitrosospira-like cluster have mostly been obtained at high salinities, while the Nitrosomonaslike cluster is dominant at low salinities (Bernhard et al., 2005; Francis et al., 2003), although both clusters have been found in different parts of the San Francisco Bay estuary (Smith et al., 2015b). In addition, AOA and AOB occupy different niches in the sediments of the estuary; AOB is more abundant where salinity is higher and the C:N ratio is lower, while AOA dominates in the part exhibiting low salinity and a high-C:N ratio (Mosier and Francis, 2008).

Depth, temperature, and $\mathrm{O}_{2}$ play significant roles in determining the community structure of AOA in coastal waters. For instance, WCA organisms are distributed at all depths, whereas WCB organisms are confined to colder, high-nutrient, low$\mathrm{O}_{2}$ and low-chlorophyll deeper waters along the Chilean and Californian coasts (Bertagnolli and Ulloa, 2017; Smith et al., 2014). In addition, AOA populations fluctuate seasonally, with abundance peaks during winter in the coastal Arctic and

25 North Sea (Christman et al., 2011; Pitcher et al., 2011b). In the Chilean coast, WCB are abundant during spring and summer and are non-detectable during winter (Bertagnolli and Ulloa, 2017).

Ammonia-oxidizing communities have also been studied in coastal microbial mats from the North Sea. In such mats AOB amo $A$ genes are significantly more abundant than AOA amo $A$ genes, and the composition and abundance of amo $A$ genes seem to be driven by salinity, temperature and nutrient concentrations (Fan et al., 2015).

30

Deep-sea environments

Deep-sea sediments and hydrothermal vent systems are sites of active nitrification that harbor diverse and novel ammoniaoxidizing prokaryotes (Dang et al., 2009a; Luo et al., 2015; Nakagawa et al., 2007). In these systems, AOA amo $A$ genes are much more diverse but less abundant than the AOB amoA genes (Cao et al., 2012; Luo et al., 2015; Nakagawa et al., 2007; 
Biogeosciences Discuss., https://doi.org/10.5194/bg-2018-279

Manuscript under review for journal Biogeosciences

Discussion started: 14 June 2018

(c) Author(s) 2018. CC BY 4.0 License.

$\mathrm{Xu}$ et al., 2014), although several exceptions have been found (Dang et al., 2009a; Yu et al., 2018). Total C and N are suggested as major factors affecting the distribution of AOA and AOB there (Luo et al., 2015; Xu et al., 2014).

Coral reefs

5 The few studies of the nitrifying ecology in coral reefs suggest that AOA may be the main contributors to $\mathrm{N}$ cycling in these

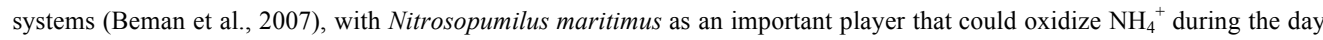
when the conditions in coral mucus are oxic (Siboni et al., 2008). However, AOB seem to dominate nitrifier communities in other coral species (Yang et al., 2013). Further research in this direction would help understand the importance of both groups involved in the nitrification of a variety of coral species.

\section{$10 \quad 2.3 \quad$ Comammox}

The process known as comammox was predicted in 2006 (Costa et al., 2006) and finally discovered in 2015 (Daims et al., 2015; van Kessel et al., 2015). The bacterial species performing complete nitrification have been classified as members of lineage II within the genus Nitrospira. Daims et al. (2015) reported the discovery of the first comammox bacteria within pipe biofilm at a $1200 \mathrm{~m}$ depth in Russia, naming it Nitrospira inopinata. Its genome contains $n x r$ genes as well as amo and hao

15 homologs. van Kessel (2015) also reported the enrichment of two Nitrospira species (Candidatus N. nitrosa and Candidatus N. nitrificans) with similar characteristics to those reported by Daims et al. (2015).

\subsubsection{Factors affecting comammox and its distribution in marine environments}

As of yet, no comammox bacteria have been found in marine environments. These microorganisms are just beginning to be studied, so the factors controlling comammox and their importance in marine environments are not well understood. It has been hypothesized that salinity could stop comammox bacteria from thriving in marine ecosystems (Kuypers, 2015), while they could be able to oxidize $\mathrm{NH}_{4}^{+}$to $\mathrm{NO}_{2}^{-}$under $\mathrm{NH}_{4}{ }^{+}$limited conditions and oxidize $\mathrm{NH}_{4}^{+}$partially to $\mathrm{NO}_{2}^{-}$under oxygenlimited conditions (Kuypers et al., 2018). Kits et al. (2017) discovered that $N$. inopinata has more affinity for $\mathrm{NH}_{4}{ }^{+}$than AOA or AOB, showing that comammox bacteria are well adapted to low $\mathrm{NH}_{4}^{+}$concentrations. The study also demonstrated that $N$. inopinata has a low affinity for $\mathrm{NO}_{2}{ }^{-}$, which may prevent it from growing as a pure nitrite oxidizer in environments

\subsection{Dissimilatory nitrate reduction to ammonia (DNRA)}


Biogeosciences Discuss., https://doi.org/10.5194/bg-2018-279

Manuscript under review for journal Biogeosciences

Discussion started: 14 June 2018

(c) Author(s) 2018. CC BY 4.0 License.

There are three purposes for $\mathrm{NO}_{3}{ }^{-}$reduction: (1) the generation of metabolic energy using the $\mathrm{NO}_{3}{ }^{-}$as an electron acceptor $\left(\mathrm{NO}_{3}{ }^{-}\right.$respiration), (2) the dissipation of excess reducing power for redox balance (dissimilatory reduction, DNRA), and (3) the use of $\mathrm{NO}_{3}{ }^{-}$as a source of $\mathrm{N}$ for growth (assimilatory reduction, ANRA), which will be addressed in the next section. DNRA can be achieved in two ways: fermentative (reaction a) and chemoautotrophic (reactions b and c). Fermentative

5 DNRA consists of the reduction of $\mathrm{NO}_{3}{ }^{-}$to $\mathrm{NO}_{2}{ }^{-}$to produce energy, and then to $\mathrm{NH}_{4}^{+}$to allow reoxidation of NADH (Tiedje, 1988). Chemoautotrophic DNRA consists of the reduction of $\mathrm{NO}_{3}{ }^{-}$using sulfide $\left(\mathrm{S}^{-2}\right)$, elemental $\mathrm{S}$, or Fe $\mathrm{F}^{+2}$ as electron donors (Robertson et al., 2016; Slobodkina et al., 2017).

a) $\mathrm{NO}_{3}{ }^{-}+2 \mathrm{H}^{+}+4 \mathrm{H}_{2} \rightarrow \mathrm{NH}_{4}{ }^{+}+3 \mathrm{H}_{2} \mathrm{O}$

b) $4 \mathrm{~S}+3 \mathrm{NO}_{3}^{-}+7 \mathrm{H}_{2} \mathrm{O} \rightarrow 4 \mathrm{SO}_{4}^{-2}+3 \mathrm{NH}_{4}^{+}+2 \mathrm{H}^{+}$

10 c) $8 \mathrm{Fe}^{+2}+\mathrm{NO}_{3}{ }^{-}+21 \mathrm{H}_{2} \mathrm{O} \rightarrow \mathrm{NH}_{4}{ }^{+}+8 \mathrm{Fe}(\mathrm{OH})_{3}+14 \mathrm{H}^{+}$

In fermentative DNRA, the initial reduction of $\mathrm{NO}_{3}{ }^{-}$to $\mathrm{NO}_{2}{ }^{-}$occurs in the same way as in denitrification and is catalyzed by either the periplasmic nitrate reductase complex (NapAB) or the membrane-bound nitrate reductase complex (NarGHI) (Moreno-Vivián et al., 1999). The reduction of $\mathrm{NO}_{2}^{-}$to $\mathrm{NH}_{4}^{+}$is catalyzed by the cytochrome $\mathrm{C}$ nitrite reductase (NrfA). Its information is encoded in the $n r f A$ gene (Kuypers et al., 2018), which is frequently used as a molecular marker for the whole DNRA process (Lam et al., 2009; Takeuchi, 2006) (Table S3 in the Supplement). In chemoautotrophic DNRA, the reduction of $\mathrm{NO}_{3}{ }^{-}$to $\mathrm{NO}_{2}{ }^{-}$is carried out by an enzymatic complex similar to Nap but encoded in the napMADGH operon. The reduction of $\mathrm{NO}_{2}^{-}$to $\mathrm{NH}_{4}^{+}$is catalyzed by alternative enzymes such as the octaheme tetrathionate reductase (Otr) or the octaheme cytochrome C nitrite reductase (Onr) (Kuypers et al., 2018).

A broad diversity of microorganisms is capable of DNRA, mainly prokaryotic organisms belonging to Proteobacteria, Firmicutes, Verrucomicrobia, Planctomycetes, Acidobacteria, Chloroflexi, and Chlorobia (Tiedje, 1988; Welsh et al., 2014) Marine eukaryotes capable of DNRA include diatoms, which use DNRA to enter a resting stage for long-term survival in dark anoxic sediments (Kamp et al., 2011, 2013), and fungi such as Aspergillus terreus isolated from the Arabian Sea OMZ, where it contributes to $\mathrm{N}$ loss by fueling anammox (Stief et al., 2014). Fermentative DNRA microbes are favored by nonsulfidic environments with high C:N ratios, whereas chemolithoautotrophic DNRA microbes prefer environments where $\mathrm{H}_{2} \mathrm{~S}$ is present in appreciable concentrations. Evidence of chemolithotrophic DNRA in marine sediments has been found in Beggiatoa, which reduces $\mathrm{NO}_{3}{ }^{-}$using $\mathrm{S}^{-2}$ as an electron donor (Preisler et al., 2007), as well as in Thermosulfurimonas dismutans and Dissulfuribacter thermophilus isolated from deep-sea hydrothermal vents; these are thermophilic anaerobic bacteria that grow autotrophically with elemental $\mathrm{S}$ as an electron donor and $\mathrm{NO}_{3}{ }^{-}$as an electron acceptor (Slobodkina et al., 2017).

30 In contrast to denitrification or anammox, DNRA produces $\mathrm{NH}_{4}^{+}$without the release of $\mathrm{N}_{2} \mathrm{O}$ or $\mathrm{N}_{2}$, thus does not cause $\mathrm{N}$ loss and contributes to primary production and nitrification. Therefore, understanding the mechanisms controlling the DNRA community and its interactions with denitrification and anammox communities is critical for understanding the fate of $\mathrm{N}$ in marine systems. 
Biogeosciences Discuss., https://doi.org/10.5194/bg-2018-279

Manuscript under review for journal Biogeosciences

Discussion started: 14 June 2018

(c) Author(s) 2018. CC BY 4.0 License.

\subsubsection{Factors affecting DNRA in marine systems}

DNRA and denitrification compete for $\mathrm{NO}_{3}{ }^{-}$and there are several factors favoring DNRA over denitrification, such as high $\mathrm{S}^{-2}$ concentrations and $\mathrm{C}: \mathrm{NO}_{3}{ }^{-}$ratios, elevated temperatures, salinity and anoxic conditions (Song et al., 2014). Although DNRA has a lower energetic yield than denitrification, it can accept a greater number of electrons per $\mathrm{NO}_{3}{ }^{-}$molecule (eight,

5 compared to five for denitrification). For this reason, DNRA may be energetically favored over denitrification in C-rich anoxic environments where $\mathrm{NO}_{3}{ }^{-}$is limiting and electron donors (organic $\mathrm{C}_{\text {or S}}{ }^{-2}$ ) are in excess (Kraft et al., 2014; Tiedje, 1988). It has been suggested that DNRA is regulated by $\mathrm{O}_{2}$ and is not affected by $\mathrm{NO}_{2}^{-}$(van den Berg et al., 2017), which contrasts with reports of DNRA rates being stimulated by $\mathrm{NO}_{2}{ }^{-}$in estuaries (Yin et al., 2017). It is also assumed that DNRA is not affected by $\mathrm{NH}_{4}^{+}$(Papaspyrou et al., 2014; Tiedje, 1988), but it has been demonstrated that $\mathrm{NH}_{4}^{+}$concentration is

10 positively correlated with DNRA rates (Lisa et al., 2015; Song et al., 2014). Salinity seems to be another factor affecting DNRA, although there is not a clear pattern. In some estuaries DNRA activity grows with increasing salinity (Gardner et al., 2006; Giblin et al., 2010; Lisa et al., 2015), while in others increasing salinity causes DNRA to decrease (Dong et al., 2009). The abundance of $n r f A$ genes is correlated with $\mathrm{S}^{-2}$ and $\mathrm{Fe}^{2+}$, which can enhance DNRA by providing extra free energy (Robertson et al., 2016; Yin et al., 2017). Elevated temperatures increase DNRA rates; therefore, DNRA may be an

15 important pathway for $\mathrm{NO}_{3}{ }^{-}$conversion during summer (Yin et al., 2017). In coastal zones, this process can also be affected by physical processes such as tides, which transport $\mathrm{NO}_{3}{ }^{-}$and support the conversion (Zheng et al., 2016).

\subsubsection{Distribution of DNRA communities in marine environments}

Since DNRA is an anaerobic process, marine DNRA communities are mostly restricted to anoxic environments such as sediments and OMZ. However, there are relatively few studies on DNRA communities in those marine systems compared to

20 the number of studies on microbes involved in other N-cycling processes (Damashek and Francis, 2017; Lam and Kuypers, 2011).

Open oceans and deep-sea environments

Only a few studies on DNRA distribution have been conducted in open oceans, most of them in OMZ. DNRA is coupled

with anammox in the Arabian sea OMZ, as indicated by ${ }^{15} \mathrm{~N}$ experiments (Jensen et al., 2011), and is carried out by microorganisms carrying divergent $n r f A$ genes (Lüke et al., 2016). DNRA has also been detected in the Peruvian OMZ, where it supplies most of the $\mathrm{NH}_{4}{ }^{+}$needed for anammox (Lam et al., 2009). However, Kalvelage et al. (2013) reported a lack of detectable $n r f A$ genes and low DNRA rates in that zone and concluded that the process is sporadic. Moreover, DNRA communities have also been found in deep-sea sediments such as those from the South China Sea, where microbes involved

30 in DNRA, ammonia oxidation and anammox are dominant ( $\mathrm{Yu}$ et al., 2018). More studies are needed to confirm the importance of the DNRA process in deep-sea environments. 
Biogeosciences Discuss., https://doi.org/10.5194/bg-2018-279

Manuscript under review for journal Biogeosciences

Discussion started: 14 June 2018

(c) Author(s) 2018. CC BY 4.0 License.

Estuaries and coastal zones

Diversity of the $n r f A$ gene in estuaries is high and often changes along salinity and $\mathrm{NO}_{3}{ }^{-}$gradients (Smith et al., 2007; Song et al., 2014; Takeuchi, 2006). There are exceptions such as in the Yellow River estuary, where the structure of DNRA communities is not affected by either type of gradient ( $\mathrm{Bu}$ et al., 2017). In addition, DNRA communities from estuarine

5 sediments are site-specific and could vary significantly at a small spatial scale (Decleyre et al., 2015). For example, the abundance of the $n r f A$ gene varies vertically in the sediments of the Yangtze estuary (China) and is greater than anammox or denitrifying genes in deeper sediments (Zheng et al., 2016). In the well-studied Colne estuary (UK), DNRA communities embedded in deeper anaerobic sediments are more homogeneous compared to those in the surface (Takeuchi, 2006). Furthermore, DNRA rates and abundance of the nrfA gene are higher at the head of that estuary, where the $\mathrm{NO}_{3}{ }^{-}$ concentration is higher (Dong et al., 2009; Smith et al., 2007). Finally, higher abundance of the $n r f A$ gene and DNRA activity have been found in estuarine sediments richer in organic $\mathrm{C}_{\text {and }} \mathrm{S}^{-2}$ (Song et al., 2014).

\subsection{Assimilatory nitrate reduction to ammonia (ANRA)}

The first step of ANRA is the reduction of $\mathrm{NO}_{3}{ }^{-}$to $\mathrm{NO}_{2}{ }^{-}$, and then to $\mathrm{NH}_{4}{ }^{+}$. This process is summarized in the following reactions:

$15 \mathrm{NAD}(\mathrm{P}) \mathrm{H}+\mathrm{H}^{+}+\mathrm{NO}_{3}^{-}+2 \mathrm{e}^{-} \rightarrow \mathrm{NO}_{2}^{-}+\mathrm{NAD}(\mathrm{P})^{+}+\mathrm{H}_{2} \mathrm{O}$

6 Ferredoxin (red) $+8 \mathrm{H}^{+}+6 \mathrm{e}^{-}+\mathrm{NO}_{2}^{-} \rightarrow \mathrm{NH}_{4}^{+}+6$ Ferredoxin (oxi) $+2 \mathrm{H}_{2} \mathrm{O}$

ANRA is performed by two classes of cytoplasmic assimilatory nitrate reductases (Nas): ferredoxin-dependent Nas (or flavodoxin-dependent Nas) and NADH-dependent Nas, which are encoded in the nas genes (Moreno-Vivián et al., 1999). $\mathrm{NO}_{3}{ }^{-}$is the major $\mathrm{N}$ source for marine eukaryotes, bacteria and archaea that contain nas genes (Moreno-Vivián et al., 1999).

\subsubsection{Factors affecting ANRA and its distribution in marine environments}

The few studies on the diversity of the nas $A$ gene have revealed that nitrate-assimilating bacteria (NAB) are widely distributed in oceanic environments (Table S4 in the Supplement). In general, temperature, $\mathrm{NO}_{3}{ }^{-}$concentration and salinity are the main factors shaping the marine NAB communities (Allen et al., 2005; Jiang et al., 2015; Jiang and Jiao, 2016). For example, marine NAB community structure and abundance are positively correlated with $\mathrm{NO}_{3}{ }^{-}$concentration (Allen et al., 2005). In addition, it has been demonstrated that $\mathrm{NH}_{4}^{+}$acts as a repressor of nas genes in isolated strains (Lledó et al., 2005). Proteobacteria, Bacteroidetes and Cyanobacteria are the dominant nasA-harboring bacteria in the South China Sea, Indian Ocean, and Pacific Ocean (Cai and Jiao, 2008; Jiang et al., 2015). The composition and diversity of NAB communities vary from one location to another and seem to be affected by salinity. For example, NAB communities in the South China Sea are more diverse than those in the Indian Ocean, while coastal NAB communities are less diverse than those from open waters. In addition, chemolithoautotrophic sulfur-oxidizing bacteria are the primary NAB in the Kueishantao hydrothermal vent, 
Biogeosciences Discuss., https://doi.org/10.5194/bg-2018-279

Manuscript under review for journal Biogeosciences

Discussion started: 14 June 2018

(c) Author(s) 2018. CC BY 4.0 License.

indicating a unique NAB community in that extreme environment (Jiang et al., 2015). Another study in the Indian Ocean indicates that NAB communities are dominated by two Gammaproteobacteria with different vertical distribution: Vibrio dominates in the euphotic layer, while Marinobacter does so at higher depths (Jiang and Jiao, 2016). Other NAB communities have been reported in the South Atlantic Bight, the North Pacific Gyre, Monterey Bay, Tampa Bay, the

5 Norwegian coast, and the Barents Sea (Adhitya et al., 2007; Allen et al., 2001, 2005; Jenkins et al., 2006).

\subsection{Denitrification}

Denitrification is a canonical, facultative, anaerobic respiratory pathway performed by a diverse array of microorganisms in which $\mathrm{NO}_{3}{ }^{-}$is respired to $\mathrm{NO}_{2}^{-}$, followed by stepwise reductions to $\mathrm{NO}, \mathrm{N}_{2} \mathrm{O}$, and $\mathrm{N}_{2}$ (Zumft, 1997). Denitrification is distributed within a taxonomically diverse group of microorganisms that can have different combinations of genes involved in the denitrification pathway (Jones et al., 2008).

The reduction of $\mathrm{NO}_{3}{ }^{-}$to $\mathrm{NO}_{2}^{-}$is catalyzed by two enzymes: NarGHI, present in a wide variety of microorganisms, and NapAB, restricted to Gram-negative bacteria (Philippot et al., 2002). The active sites of both complexes are encoded in $n a r G$ and napA genes, which have been frequently used as biomarkers for the microorganisms involved in this process in marine systems (Lam et al., 2009; Smith et al., 2007) (Table S5 in the Supplement). Nitrate reduction is a major source of $\mathrm{NO}_{2}{ }^{-}$for

15 other N-cycling processes, including aerobic nitrite oxidation and anammox (Kuypers et al., 2018).

Two isofuctional periplasmic enzymes catalyze the reduction of $\mathrm{NO}_{2}{ }^{-}$to $\mathrm{NO}$ : a Cu-containing nitrite reductase (encoded by nirK) and a haem-containing cd1 nitrite reductase (encoded by nirS), with most denitrifying bacteria containing one of the two enzymes (Zumft, 1997). Because this is the first committed step of the pathway to a $\mathrm{N}$ gaseous product, nir genes are the most widely used markers for denitrifiers (Braker et al., 2000; Mosier and Francis, 2010; Ward et al., 2009) (Table S5 in the Supplement). Notwithstanding, these genes are present in many other microorganisms, including anammox bacteria, nitrite and methane-oxidizing bacteria, AOA and AOB (Kuypers et al., 2018). The taxonomic diversity of nirK-denitrifiers is greater than that of nirS-denitrifiers, likely due to horizontal gene transfer. Furthermore, nirS-denitrifiers seem to have a complete denitrification pathway (including nor and nos genes); thus, they are more likely to completely reduce $\mathrm{NO}_{2}{ }^{-}$to $\mathrm{N}_{2}$ (Graf et al., 2014). In addition, the distribution of nir-containing denitrifiers is environment-specific and seems to be 25 controlled by redox conditions, with nirS communities prevailing under lower dissolved oxygen regimes (Kim et al., 2011; Pajares et al., 2017).

The conversion of $\mathrm{NO}$ to $\mathrm{N}_{2} \mathrm{O}$ is carried out by two types of nitric oxide reductases (NOR): a cytochrome c-dependent complex (cNOR) present almost exclusively in denitrifiers, and a quinol-dependent complex (qNOR) present in microorganisms with incomplete denitrifying molecular machinery (Hino et al., 2010). cNOR is the most studied NOR and is composed of the subunits NorB and NorC. NorB is encoded in the homonymous gene, which is present in denitrifying bacteria and several AOB (Casciotti and Ward, 2005); it has been used as a biomarker for the microorganisms involved in the reduction of NO (Braker and Tiedje, 2003). 
Biogeosciences Discuss., https://doi.org/10.5194/bg-2018-279

Manuscript under review for journal Biogeosciences

Discussion started: 14 June 2018

(c) Author(s) 2018. CC BY 4.0 License.

The final step in the denitrification pathway is the reduction of $\mathrm{N}_{2} \mathrm{O}$ to $\mathrm{N}_{2}$. It is catalyzed by the nitrous oxide reductase (NOS), which is encoded in the nos $Z$ gene and is frequently used as a biomarker for the study of denitrifier communities capable of reducing $\mathrm{N}_{2} \mathrm{O}$ in marine systems (Bowles et al., 2012; Castro-González et al., 2015; Wittorf et al., 2016) (Table S5 in the Supplement). There are two phylogenetically distinct nos $Z$ clades: clade I includes organisms with a complete 5 denitrification pathway, whereas clade II includes organisms that frequently lack other denitrification genes (Jones et al., 2013).

\subsubsection{Factors affecting denitrification in marine systems}

Oxygen is the main driver of denitrifier communities in marine systems, since denitrification is limited to environments where $\mathrm{O}_{2}$ is nearly fully depleted $\left(<5 \mu \mathrm{mol} \mathrm{O}_{2} / \mathrm{L}\right)$. It has been reported that $\operatorname{nir} S$, nor $B$ and nos $Z$ genes strongly decrease in $\mathrm{O}_{2}$ concentrations $>200 \mathrm{nM}$ (Dalsgaard et al., 2014). For instance, the nirS gene is rarely present in well-oxygenated waters or waters containing $\mathrm{H}_{2} \mathrm{~S}$, and is found at high concentrations in the Arabian Sea OMZ (Jayakumar et al., 2004; Ward et al., 2009). Furthermore, $\mathrm{O}_{2}$ availability is associated with the habitat partitioning of $\mathrm{N}_{2} \mathrm{O}$ reducers in coastal marine surface sediments (Wittorf et al., 2016). Other factors affecting marine denitrification vary from one environment to another. For example, in some OMZs, such as those in the Eastern Tropical North and South Pacific, denitrification appears to be limited

15 by organic $\mathrm{C}$, while in others, such as the Arabian Sea OMZ, is unaffected by it (Ward et al., 2008). In the OMZs of the Eastern South Pacific and the Mexican Pacific coast, denitrifying communities are affected by $\mathrm{NO}_{3}{ }^{-}$and $\mathrm{NO}_{2}{ }^{-}(\mathrm{Castro}-$ González et al., 2005; Liu et al., 2003). Organic matter and salinity are among the key factors controlling denitrification rates, as well as denitrifier community abundance and composition in estuaries (Francis et al., 2013, Lee and Francis 2017; Mosier and Francis, 2010; Zhang et al., 2014b). The clay percentage and pH are other important factors influencing the abundance of nir genes in intertidal sediments (Wang et al., 2014). Since NosZ requires copper, it could represent a regulating factor in denitrification and the production of $\mathrm{N}_{2} \mathrm{O}$ in marine environments (Granger and Ward, 2003). As mentioned before, denitrification and DNRA compete for $\mathrm{NO}_{3}{ }^{-}$, and factors such as low $\mathrm{S}^{-2}$ concentrations (which inhibit the last two steps of denitrification), cold temperatures and a low $\mathrm{C}: \mathrm{NO}_{3}{ }^{-}$ratio favor denitrification over DNRA (Burgin and Hamilton, 2007; Song et al., 2014).

\subsubsection{Distribution of denitrifier communities in marine environments}

Although denitrifying microorganisms can be found in any marine environment, denitrification is typically restricted to suboxic or anoxic environments such as OMZs and sediments.

Open oceans and deep-sea environments 
Biogeosciences Discuss., https://doi.org/10.5194/bg-2018-279

Manuscript under review for journal Biogeosciences

Discussion started: 14 June 2018

(c) Author(s) 2018. CC BY 4.0 License.

OMZs are considered one of the major oceanic sites of denitrification. For example, denitrification is the dominant N-loss pathway in the Arabian Sea OMZ (Ward et al., 2009), where denitrifiers dominate over anammox bacteria (Jayakumar et al., 2004; Jayakumar et al., 2009). Depth distributions of nir genes follow the same pattern in the Arabian Sea and the Eastern Tropical South Pacific, where they are associated with the secondary $\mathrm{NO}_{2}^{-}$maximum in oxygen-depleted waters. However,

5 the denitrifier community composition of the two sites seems to be different (Castro-González et al., 2005; Jayakumar and Ward, 2013). In the Eastern Tropical North Pacific, narG seems to be the most abundant denitrifying gene, while nirK dominates over nirS and the two nos $Z$ clusters based on depth distributions corresponding to two $\mathrm{N}_{2} \mathrm{O}$ peaks (Fuchsman et al., 2017). Unlike nirS-based communities in the Black Sea suboxic zone, nirK-based communities generally vary with depth, while the composition of both nirK and nirS genes changes dramatically at the bottom of this suboxic zone (Oakley et al., 2007). Great genomic potential for full denitrification to $\mathrm{N}_{2}$ has been found in Bothnian Sea sediments located in the northern Baltic Sea, with higher abundance of narG-, nirS- and nosZ-encoding gene reads but minor importance of genomic potential for anammox and DNRA (Rasigraf et al., 2017). In addition, the composition of nirS-based communities is sitespecific in the Baltic Sea and varies along biogeochemical gradients $\left(\mathrm{H}_{2} \mathrm{~S}, \mathrm{NH}_{4}{ }^{+}, \mathrm{NO}_{3}{ }^{-}\right.$and $\left.\mathrm{O}_{2}\right)$ in the water column, while it is uniform in the sediment (Falk et al., 2007; Hanning et al., 2006).

15 Few studies of denitrifier communities have been conducted in deep-sea sediments or hydrothermal vents, where chemolithotrophic denitrification is expected to be an important process given the high concentration of reduced sulfur species in such environments. For example, nirS sequences have been retrieved from a hydrothermal vent system in the Juan de Fuca Ridge (Bourbonnais et al., 2014) and from deep-sea sediments in the Nankai Trough, where nirK-type denitrifiers were undetected (Tamegai et al., 2007).

20

Estuaries and coastal environments

Denitrification is often the major process driving $\mathrm{N}$ removal from coastal and estuarine environments (Damashek and Francis, 2017; Devol, 2015). Sediments provide ideal conditions for this process, due to the narrow spatial scale for diffusion across redox boundaries. Therefore most studies have documented the abundance or diversity of nir genes in estuary

25 sediments, with a few of them in estuary waters (Zhang et al., 2014b). The dominant denitrifying gene ecotypes identified in these systems are not affiliated with known denitrifying strains (Francis et al., 2013; Lee and Francis, 2017; Santoro et al., 2006). In general, nirS genes are more abundant and diverse than nirK in estuary sediments (e.g., Abell et al., 2010; Lee and Francis, 2017; Magalhães et al., 2011; Mosier and Francis, 2010; Santoro et al., 2006; Smith et al., 2015a; Wang et al., 2014). For example, nirS-type denitrifiers dominate in shallow bay sediments from the South China Sea, whereas nirK-type denitrifiers go undetected (Yu et al., 2018). Diversity and abundance of denitrifiers often change along the estuarine salinity gradient, with distinct communities in fresh and marine regions (Abell et al., 2013; Francis et al., 2013; Lee and Francis, 2017). For instance, in the San Francisco Bay estuary, the abundance of nirK genes seems to be higher in the riverine zone whereas nirS genes are more abundant in zones that are more marine (Mosier and Francis, 2010). Additionally, nitrate and 
Biogeosciences Discuss., https://doi.org/10.5194/bg-2018-279

Manuscript under review for journal Biogeosciences

Discussion started: 14 June 2018

(c) Author(s) 2018. CC BY 4.0 License.

nitrite reductase gene copy numbers decline significantly from the head towards the mouth of the Colne estuary (Smith et al., 2007).

It is worth noting that denitrification has also been proved to happen in particular marine environments and organisms. For example, it has been shown that Trichodesmium harbors denitrifier communities composed by Alphaproteobacteria that

5 actively express nosZ, showing that Trichodesmium colonies are potential sites of $\mathrm{N}_{2} \mathrm{O}$ reduction (Coates and Wyman, 2017). In addition, sinking copepod carcasses have anoxic interiors that support the expression of nirS genes, representing hotspots of pelagic denitrification (Glud et al., 2015). Finally, certain benthic foraminifera appear to be capable of accumulating and respiring $\mathrm{NO}_{3}{ }^{-}$through denitrification (Piña-Ochoa et al., 2010; Risgaard-Petersen et al., 2006).

$10 \quad 2.7$ Nitrate/Nitrite-dependent anaerobic methane oxidation

Anaerobic methane oxidation coupled with denitrification, also known as nitrate/nitrite-dependent anaerobic methane oxidation (n-damo), was discovered in 2006 and constitutes a unique link between the two major global nutrient cycles of C and $\mathrm{N}$ (Raghoebarsing et al., 2006). The process is given by the following reactions:

(1) $\mathrm{CH}_{4}+4 \mathrm{NO}_{3}^{-}+8 \mathrm{H}^{+} \rightarrow \mathrm{CO}_{2}+4 \mathrm{NO}_{2}{ }^{-}+10 \mathrm{H}_{2} \mathrm{O}$

15 (2) $3 \mathrm{CH}_{4}+8 \mathrm{NO}_{2}^{-}+8 \mathrm{H}^{+} \rightarrow 3 \mathrm{CO}_{2}+4 \mathrm{~N}_{2}+10 \mathrm{H}_{2} \mathrm{O}$

The n-damo process is carried out by bacteria from the $\mathrm{NC10}$ phylum and ANME archaea in a syntrophic manner. Candidatus Methanoperedens nitroreducens (ANME-2d) is one of the microorganisms capable of performing reaction (1) (Haroon et al., 2013), while Candidatus Methylomirabilis oxyfera (a member of the NC10 phylum) is capable of performing reaction (2) (Ettwig et al., 2010). The metabolism of $M$. nitroreducens is highly complex, and includes genes related to reverse methanogenesis (Haroon et al., 2013; Timmers et al., 2017). The metabolism of M. oxyfera is also complex and unusual, because in spite of being considered an anaerobic microorganism, it is able to oxidize methane $\left(\mathrm{CH}_{4}\right)$ using enzymes found in aerobic methanotrophs (Ettwig et al., 2010) such as the particulate methane-monooxygenase (pMMO), encoded in the pmoA gene, which has been used as a biomarker in marine systems (Chen et al., 2016; Padilla et al., 2016) (Table S6 in the Supplement). The metabolism of $M$. oxyfera has been described as "intra-aerobic" and consists of the 25 intracellular production of $\mathrm{O}_{2}$ by dismutating $\mathrm{NO}$ into $\mathrm{O}_{2}$ and $\mathrm{N}_{2}$, catalyzed by the nitric oxide dismutase (NOD) (Ettwig et al., 2010). The genome of M. oxyfera also encodes NirS and three qNOR, which may participate in detoxifying processes (Wu et al., 2011).

\subsubsection{Factors affecting n-damo and its distribution in marine systems}

The n-damo process has just begun to be studied, and only a few works on the distribution of these microorganisms in marine environments and the factors affecting their distribution are available. In oceanic environments, $\mathrm{n}$-damo has been detected in OMZs, which represent a niche for NC10 bacteria (Chronopoulou et al., 2017; Padilla et al., 2016). For example, 
Biogeosciences Discuss., https://doi.org/10.5194/bg-2018-279

Manuscript under review for journal Biogeosciences

Discussion started: 14 June 2018

(c) Author(s) 2018. CC BY 4.0 License.

in the $\mathrm{OMZ}$ off northern Mexico and Costa Rica, 16S rRNA showed a peak abundance of NC10 bacteria in the anoxic zone with high $\mathrm{NO}_{3}{ }^{-}$and $\mathrm{CH}_{4}$ concentrations (Padilla et al., 2016).

M. oxyfera-like bacteria have also been detected in estuaries. In the sediments of Zhangjiang estuary, M. oxyfera-like bacteria show great diversity and a depth-specific distribution influenced by redox potential, water content and total organic

5 C (Zhang et al., 2018). In the Jiaojiang estuary, organic content seems to be the most important factor affecting the distribution of n-damo communities, $\mathrm{NC10}$ bacteria being more abundant in the intertidal than in the subtidal sediments (Lidong et al., 2014). In addition, the activity of NC10 bacteria varies seasonally and spatially in the coastal sediments of the East China Sea, being higher in the spring and lower in the intertidal zone (Wang et al., 2017). The structure of this community in coastal sediments seems to be highly influenced by $\mathrm{NO}_{3}{ }^{-}$concentrations (Wang et al., 2017), as well as by

$10 \mathrm{NH}_{4}^{+}$and $\mathrm{NO}_{2}^{-}$(Chen et al., 2015).

In general, $\mathrm{n}$-damo microorganisms are favored by low $\mathrm{SO}_{4}^{-2}$ concentrations (due to the elimination of competition with $\mathrm{SO}_{4}$ ${ }^{2}$ reducers) and high $\mathrm{CH}_{4}$ concentrations. In addition, it is believed that the abundance of these microorganisms is controlled by $\mathrm{NO}_{2}{ }^{-}$due to possible competition with denitrifying and anammox microorganisms. If anammox bacteria are not limited by $\mathrm{NH}_{4}^{+}$concentrations, they are more competent for $\mathrm{NO}_{2}^{-}$than $\mathrm{n}$-damo microorganisms (Luesken et al., 2011). The

15 importance of $\mathrm{n}$-damo microorganisms in the $\mathrm{C}$ and $\mathrm{N}$ cycles, in addition to the small number of studies on their distribution, clearly warrant further study to ascertain the drivers of these communities in different marine ecosystems.

\subsection{Anammox}

The anaerobic oxidation of ammonium, anammox, consists in the conversion of $\mathrm{NH}_{4}^{+}$and $\mathrm{NO}_{2}^{-}$to $\mathrm{N}_{2}$ (4) in the absence of $\mathrm{O}_{2}$, and involves three reactions (1-3):

20 (1) $\mathrm{NO}_{2}^{-}+2 \mathrm{H}^{+}+\mathrm{e}^{-} \rightarrow \mathrm{NO}+\mathrm{H}_{2} \mathrm{O}$

(2) $\mathrm{NH}_{4}^{+}+\mathrm{NO}+2 \mathrm{H}^{+} 3 \mathrm{e}^{-} \rightarrow \mathrm{N}_{2} \mathrm{H}_{4}+\mathrm{H}_{2} \mathrm{O}$

(3) $\mathrm{N}_{2} \mathrm{H}_{4} \rightarrow \mathrm{N}_{2}+4 \mathrm{H}^{+}+4 \mathrm{e}^{-}$

(4) $\mathrm{NH}_{4}^{+}+\mathrm{NO}_{2}^{-} \rightarrow \mathrm{N}_{2}+2 \mathrm{H}_{2} \mathrm{O}$

25 Reaction (1) is catalyzed by the NirS, while reaction (2) is carried out by the hydrazine synthase (HZS). Enzyme-catalyzing reaction (3) has been called many names over the years, such as hydrazine oxidase (HZO) or hydrazine dehydrogenase (HDH) (Kartal et al., 2011). Various functional genes have been used as anammox biomarkers in marine systems (Table S7 in the Supplement): Scalindua-like nirS, which codes for a NirS specific to Scalindua, the dominant anammox bacteria in marine OMZs (Lam et al., 2009; Li et al., 2013); hzoAB (Hirsch et al., 2011; Lisa et al., 2014), which codes for part of the $\mathrm{HZO}$, and with numerous divergent copies in a number of anammox bacteria (Strous et al., 2006); and $h z s A$ or $h z s B$, coding for part of the HZS, which have been suggested as the most suitable biomarkers for the process (Han et al., 2017; Harhangi et al., 2012; Nunoura et al., 2013). 
Biogeosciences Discuss., https://doi.org/10.5194/bg-2018-279

Manuscript under review for journal Biogeosciences

Discussion started: 14 June 2018

(c) Author(s) 2018. CC BY 4.0 License.

Until now, ten Candidatus species belonging to five genera have been reported as responsible for anammox, all of them within a deep, monophyletic branch in the order Planctomycetales: Kuenenia, Anammoxoglobus and Jettenia with one species each, Brocadia with three species, and Scalindua with four (Kartal et al., 2012; Van de Vossenberg et al., 2013). Anammox bacteria are autotrophs, active at a wide range of temperatures $\left(1.8^{\circ} \mathrm{C}-85^{\circ} \mathrm{C}\right)$ and with great affinity for $\mathrm{NO}_{2}{ }^{-}$

5 and $\mathrm{NH}_{4}^{+}$, even in concentrations below $5 \mu \mathrm{M}$ (Jetten et al., 2009). These slow-growing anaerobic microorganisms are difficult to culture and possess a unique capability of producing and converting $\mathrm{N}_{2} \mathrm{H}_{4}$ in a ladderane lipid membrane called the anammoxosome (Kartal et al., 2012).

\subsubsection{Factors affecting anammox in marine systems}

Although the presence of anammox bacteria may not be indicative of high anammox activity, several studies have shown that anammox bacterial gene abundance positively correlates with anammox rates in marine environments (Bale et al., 2014; Hou et al., 2013; Lisa et al., 2014). In general, anammox activity is mainly regulated by $\mathrm{O}_{2}$ and inorganic $\mathrm{N}$ concentrations and seems to be coupled with nitrification (Lam et al., 2007), denitrification (Dalsgaard et al., 2003) and DNRA (Jensen et al., 2011). Despite being described as obligated anaerobes active only at $\mathrm{O}_{2}$ concentrations below $2 \mu \mathrm{M}$, anammox bacteria are resistant to $\mathrm{O}_{2}$ exposure; nevertheless, the process is inhibited at high $\mathrm{O}_{2}$ concentrations (Jetten et al., 2009). It has been assumed that anammox bacteria in OMZs may be more frequently limited by $\mathrm{NH}_{4}^{+}$than by $\mathrm{NO}_{2}^{-}$, because $\mathrm{NH}_{4}^{+}$ concentrations in OMZs are typically lower than those of $\mathrm{NO}_{2}^{-}$(Lam et al., 2009). However, studies have shown that $\mathrm{O}_{2}$ and $\mathrm{NO}_{2}{ }^{-}$co-limit the distribution of anammox bacteria in the OMZ of the Black Sea (Lam et al., 2007), Arabian Sea (Pitcher et al., 2011) and Eastern Tropical North Pacific (Kong et al., 2013; Rush et al., 2012). It has been also reported that the availability of $\mathrm{NO}_{3}{ }^{-}, \mathrm{NO}_{2}^{-}$, and $\mathrm{NH}_{4}^{+}$regulates anammox activity in coastal and estuary sediments (Nicholls and Trimmer, 2009; Risgaard-Petersen et al., 2004; Teixeira et al., 2016; Trimmer et al., 2005), in which the fluctuating availability of $\mathrm{O}_{2}$, $\mathrm{NO}_{3}{ }^{-}$and $\mathrm{NO}_{2}{ }^{-}$typically favors denitrifying microorganisms over anammox bacteria (Risgaard-Petersen et al., 2005). In addition, in many marine environments anammox activity and bacterial distribution are highly dependent upon organic $\mathrm{C}$ content (Shehzad et al., 2016; Trimmer et al., 2003), salinity (Hou et al., 2013; Rich et al., 2008; Shehzad et al., 2016; Sonthiphand et al., 2014) and temperature (Rysgaard-Petersen et al., 2004; Shehzad et al., 2016). For example, in eutrophic environments, high organic $\mathrm{C}$ concentrations usually stimulate denitrification while suppressing anammox because of the competition for $\mathrm{NO}_{2}{ }^{-}$(Brin et al., 2014; Jäntti et al., 2011; Nicholls and Trimmer, 2009). However, a number of studies have found positive correlations between organic $\mathrm{C}$ content in marine sediments and anammox rates caused by high production of $\mathrm{NH}_{4}^{+}$or $\mathrm{NO}_{2}^{-}$from heterotrophic remineralization and nitrification (Bale et al., 2014; Lisa et al., 2015; Trimmer et al., 2003). Furthermore, anammox activity has been found to be strongly correlated with the sinking of organic matter in the Tropical South Pacific OMZ (Kalvelage et al. 2013). These contradictions show that understanding the relationship between organic $\mathrm{C}$ content and anammox is still an open question. Finally, anthropogenic contaminants in marine 
Biogeosciences Discuss., https://doi.org/10.5194/bg-2018-279

Manuscript under review for journal Biogeosciences

Discussion started: 14 June 2018

(c) Author(s) 2018. CC BY 4.0 License.

environments, such as heavy metals, have also been identified as key factors influencing the ecology and biogeochemical functioning of anammox bacteria (Dang et al., 2013).

\subsubsection{Distribution of anammox bacteria in marine environments}

Anammox bacteria contribute to approximately $30-60 \%$ of marine $\mathrm{N}$ loss and are present and active in a wide range of 5 marine environments, especially in oxygen-depleted settings such as the water column and OMZ sediments (e.g., Galán et al., 2009; Kuypers et al., 2003; Jensen et al., 2011; Lam et al., 2007; Ward et al., 2009), eutrophic bays (e.g., Dang et al., 2010; Lisa et al., 2014), estuarine sediments (e.g., Brin et al., 2014; Li et al., 2011; Tal et al., 2005; Trimmer et al., 2005), fjord sediments (Brandsma et al., 2011; Risgaard-Petersen et al., 2004), Arctic sediments (Rysgaard et al., 2004), deep ocean sediments (Hong et al., 2011a, 2011b; Shao et al., 2014), and deep-sea hydrothermal vents (Byrne et al., 2009). Below, we summarize the main findings from a large number of studies on the distribution of anammox bacteria in the most representative marine environments.

\section{Open oceans}

The release of $\mathrm{NH}_{4}^{+}$and $\mathrm{NO}_{2}^{-}$through incomplete denitrification and deficient dissolved oxygen makes OMZs ideal

15 environments for the growth of anammox bacteria. These microorganisms are found in different OMZs such as those in the Baltic Sea (Kuypers et al., 2003), Golfo Dulce (Dalsgaard et al., 2003), Eastern Tropical North Pacific (Kong et al., 2013; Rush et al., 2012), Eastern Tropical South Pacific (Galan et al., 2009), Colombian Pacific (Castro-González et al., 2014), Arabian Sea (Jaeschke et al., 2007; Jensen et al., 2011; Ward et al., 2009) and Benguela (Kuypers et al., 2005), where the anammox process accounts for between one-fifth and all of $\mathrm{N}_{2}$ production (Dalsgaard et al., 2005). In fact, anammox is the dominant N-loss pathway in the Benguela upwelling system (Kuypers et al., 2005), the Black Sea (Lam et al., 2007) and the Peruvian OMZ (Hamersley et al., 2007). A low diversity of anammox communities has been detected in OMZ waters (Kong et al., 2013; Schmid et al., 2007), in which mainly two clades of Ca. Scalindua typically predominate: Clade 1 (Ca. Scalindua sorokinii/brodae) in the Peruvian and Namibian OMZs, and clade 2 (Ca. Scalindua arabica) in the Peruvian and the Arabian Sea OMZs (Woebken et al., 2008). Another study in the Baltic Sea suboxic zone indicates that Ca. Scalindua species split into two clusters in that environment: $\mathrm{Ca}$. Scalindua richardsii, present in the upper suboxic zone at high $\mathrm{NO}_{2}$ and $\mathrm{NO}_{3}{ }^{-}$and low $\mathrm{NH}_{4}{ }^{+}$concentrations, and $\mathrm{Ca}$. Scalindua sorokinii, present in the lower suboxic zone at high $\mathrm{NH}_{4}{ }^{+}$and low $\mathrm{NO}_{3}{ }^{-}$concentrations (Fuchsman et al., 2012). Sediments from the north marginal seas in China harbor two potential novel anammox bacteria, with Ca. Scalindua being the most abundant in said environments (Shehzad et al., 2016).

Anammox has been reported in different estuarine environments, such as the Thames estuary (Trimmer et al., 2003), the New England estuary (Brin et al., 2014), the New River estuary (Lisa et al., 2015), the Randers Fjord (Risgaard-Petersen et 
Biogeosciences Discuss., https://doi.org/10.5194/bg-2018-279

Manuscript under review for journal Biogeosciences

Discussion started: 14 June 2018

(c) Author(s) 2018. CC BY 4.0 License.

al., 2004), and the Yangtze estuary (Hou et al., 2013), where anammox bacterial diversity and distribution are mainly affected by salinity gradients (Sonthiphand et al., 2014). Other reports of the presence of anammox bacteria comprise coastal areas such as the Inner Harbor (Tal et al., 2005), and coastal sediments from Europe, North America (Engström et al., 2005) and the Bohai Sea (Dang et al., 2013). Ca. Scalindua typically dominates throughout estuarine sediments (Dang et al., 2010;

5 Hirsch et al., 2011; Rich et al., 2008; Tal et al., 2005), while Ca. Brocadia, Ca. Kuenenia, Ca. Anammoxoglobous and Ca. Jettenia are mainly found in fresh to oligohaline sediments (Dale et al., 2009; Hirsch et al., 2011).

Deep-sea and other environments

Deep-sea and other extreme environments seem to harbor a great diversity of anammox species. For example, a high diversity of Ca. Scalindua, grouped into five clusters, was found in deep-sea sediments from the South China Sea (Hong et al., 2011a). Anammox bacteria are also present and active in hydrothermal vent areas, such as those in the Mid-Atlantic Ridge, where $\mathrm{Ca}$. Kuenenia was found at $300^{\circ} \mathrm{C}$ (Byrne et al., 2009), and the Okhotsk Sea, where hzo genes are highly abundant (Shao et al., 2014). A study in the Guaymas Basin revealed that Ca. Scalindua species are more abundant in cold hydrocarbon-rich sediments than hydrothermal vents (Russ et al., 2013).

\section{Effects of anthropogenic activity on the marine nitrogen cycle}

The marine $\mathrm{N}$ cycle is currently being largely perturbed by human activity. Recent findings show that the oceanic $\mathrm{N}$ budget balance leans more significantly towards higher losses than inputs (Codispoti et al., 2001; Gruber and Galloway, 2008; Voss et al., 2013). Anthropogenic activities pertaining to the production of artificial fertilizers and fossil fuel combustion are mainly responsible for this imbalance, affecting the marine $\mathrm{N}$ cycle directly or indirectly (Fig. 3). Direct alterations include the input of fixed $\mathrm{N}$ through riverine discharges and atmospheric deposition (Duce et al., 2008; Jickell et al., 2017). Large anthropogenic $\mathrm{N}$ inputs cause eutrophication and the formation of anoxic or hypoxic areas (“dead zones"), impacting primary production and the marine trophic web (Vaquer-Sunyer and Duarte, 2008) with consequent ecosystemic collapse (Diaz and Rosenberg, 2008). Indirect alterations include activities that increase the atmospheric concentration of greenhouse gases, leading to ocean warming, acidification and deoxygenation (Hutchins and Fu, 2017). The scale and impact of such anthropogenic perturbation of the marine $\mathrm{N}$ cycle remain highly uncertain (Gruber, 2016; Hutchins and Fu, 2017).

Estimated anthropogenic release of $\mathrm{N}$ into the global environment $\left(\sim 160 \mathrm{Tg} \mathrm{N} \mathrm{yr}^{-1}\right)$ is now of similar magnitude to all natural global ocean $\mathrm{N}_{2}$ fixation $\left(\sim 140 \mathrm{Tg} \mathrm{N} \mathrm{yr}^{-1}\right)$, and may increase along with growing global population (Eugster and Gruber, 2012; Gruber and Galloway, 2008). Modeling studies have shown that the predicted anthropogenic increase in atmospheric $\mathrm{N}$ deposition could initiate a series of strong negative feedback in the marine $\mathrm{N}$ cycle. There could be a pronounced decrease

30 in global ocean $\mathrm{N}_{2}$ fixation and an increase in denitrification, which would compensate for much of the enhanced $\mathrm{N}$ input and limit the impact of atmospheric N deposition on marine productivity (Somes et al., 2016; Yang and Gruber, 2016). 
Biogeosciences Discuss., https://doi.org/10.5194/bg-2018-279

Manuscript under review for journal Biogeosciences

Discussion started: 14 June 2018

(c) Author(s) 2018. CC BY 4.0 License.

Ocean warming enhances water stratification and decreases oxygen solubility, causing a major loss of $\mathrm{O}_{2}$ from the future ocean (Dybas, 2005). Worldwide expansion of dead zones and OMZs will have large impacts on microbially mediated $\mathrm{N}$ processes in marine ecosystems. The hypoxic conditions of these environments may favor $\mathrm{N}_{2}$ fixation (since nitrogenase is strongly inhibited by $\mathrm{O}_{2}$; Sohm et al., 2011) and anaerobic $\mathrm{N}$ cycling processes, such as denitrification and anammox, since

$5 \mathrm{~N}$ isotopic labeling analyses suggest that both processes are strongly negatively correlated with $\mathrm{O}_{2}$ concentration $($ Kalvelage et al., 2011; Neubacher et al., 2013; Ward et al., 2009). Global proliferation of suboxic waters could also promote nitrification, since this process occurs at high rates in transitional regions around $\mathrm{OMZs}_{\mathrm{s}}$ were $\mathrm{O}_{2}$ is low but not fully depleted (Lam et al., 2009). Furthermore, ocean warming will likely cause an increase of $\mathrm{N}_{2}$ fixation, since enzyme activity increases at higher temperatures and higher ocean surface temperatures will lead to an expansion of habitats suitable for diazotrophs (Hutchins et al., 2009). An increase in marine $\mathrm{N}_{2}$ fixation would therefore lead to an increase in the amount of $\mathrm{Nr}$ available for further processes in the $\mathrm{N}$ cycle.

Ocean acidification may stimulate $\mathrm{N}_{2}$-fixation rates and reduce nitrification rates within coming decades. A number of studies have documented the positive effects of elevated $\mathrm{CO}_{2}$ on marine $\mathrm{N}_{2}$-fixing cyanobacteria (Hutchins et al., 2007; Lomas et al., 2012; Rees et al., 2017) but others did not find a clear response (Böttjer et al., 2014; Law et al., 2012), possibly

15 due to regional and taxonomic differences or other associated environmental factors. For instance, a decrease in $\mathrm{pH}$ due to ocean acidification may lead to a decrease in the bioavailability of Fe (Shi et al., 2010), which may in turn lead to a decrease in $\mathrm{N}_{2}$ fixation in areas where Fe is limiting. On the other hand, acidification experiments have demonstrated decreases in $\mathrm{NH}_{3}$ oxidation due to the incremental protonation of $\mathrm{NH}_{3}$ (the substrate for microbial ammonia oxidizers) to $\mathrm{NH}_{4}^{+}$as seawater pH decreases (Beman et al., 2011; Kitidis et al., 2011).

20 Denitrification and nitrification processes are responsible for $87 \%$ of the annual global $\mathrm{N}_{2} \mathrm{O}$ budget $\left(18.8 \mathrm{Tg} \mathrm{N}^{-1}\right.$; $\mathrm{Syakila}$ and Kroeze, 2011), with a 30\% contribution from the world's oceans (Voss et al., 2013). The heat-trapping capacity of $\mathrm{N}_{2} \mathrm{O}$ is 300 times that of $\mathrm{CO}_{2}$ (Rodhe, 1990), thus it plays a key role in the greenhouse effect and climate regulation. Additionally, $\mathrm{N}_{2} \mathrm{O}$ acts as a source of $\mathrm{NO}$ and $\mathrm{N}$ dioxide $\left(\mathrm{NO}_{2}\right)$, gases involved in ozone $\left(\mathrm{O}_{3}\right)$ depletion in the stratosphere and acid rain formation (Ravishankara et al., 2009). $\mathrm{O}_{3}$ depletion results in increased UVB irradiance that threatens nutrient cycling, primary production, community diversity and species composition by harming phytoplankton and other organisms (El-Sayed et al., 1996 and references therein). Consequently, the marine pathways of $\mathrm{N}_{2} \mathrm{O}$ and the quantification of its oceanic emissions have recently received increased attention (Babbin et al., 2015; Freing et al., 2012).

Finally, $\mathrm{N}$ cycling is connected to the cycles of biologically important elements such as those of C and phosphorous, which implies that human alterations of marine $\mathrm{N}$ cycling are likely to have major consequences for other biogeochemical processes and affect marine ecosystem functions and services. However, the understanding of these consequences is poor due to the lack of globally empirical studies and sufficiently global models (Fowler et al., 2015).

\section{Conclusions and perspectives}


Biogeosciences Discuss., https://doi.org/10.5194/bg-2018-279

Manuscript under review for journal Biogeosciences

Discussion started: 14 June 2018

(c) Author(s) 2018. CC BY 4.0 License.

In this review, we have provided a panorama of the biochemistry, genetics, ecology and distribution of marine N-cycling microbes and the processes they mediate. These microorganisms are more widely distributed than previously thought, given that they have been found in unpredicted marine environments. Plus, many new metabolic pathways for N compounds have been reported over the past few years, completely changing the paradigm of the classic marine $\mathrm{N}$ cycle. The activity and

5 distribution patterns of N-cycling microbes in marine ecosystems seem to be dictated by site-specific factors, of which temperature, salinity, $\mathrm{O}_{2}$ and inorganic $\mathrm{N}$ forms are among the main factors controlling these communities in most cases. Additionally, we have examined the potential effects of human activity on microbially mediated N-cycling processes; such activity has led to an alteration of the natural balance of the marine $\mathrm{N}$ cycle, with consequences that we are just beginning to experience and comprehend.

10 We have also identified large knowledge gaps regarding microbially mediated $\mathrm{N}$ processes in marine ecosystems, and these represent potential areas of exploration. Future research should focus on: 1) detecting novel N-cycling processes, such as comammox and n-damo, in marine ecosystems and taking steps to further understand the physiology, metabolisms and ecology of participating microorganisms, 2) further investigation of the distribution of previously established processes, such as ANRA and DNRA, in marine ecosystems, 3) investigating the interactions between DNRA, denitrifier and anammox

15 communities in different marine environments, 4) exploring $\mathrm{N}$ cycle processes and the microbial communities involved in little-studied environments (e.g., $\mathrm{N}_{2}$ fixation in the Indian Ocean and coastal zones, nitrification in coral reefs, and denitrification in deep sea environments), and 5) further analysis and modeling of the potential effects of anthropogenic activity on marine $\mathrm{N}$ processes, and how these effects interact with other biogeochemical processes.

Author contributions. Both authors contributed equally to the manuscript.

Competing interests. The authors declare that they have no conflict of interest.

Acknowledgements. R. Ramos's Master studies were supported by a CONACYT scholarship. Funding for this work was

25 granted by PAPIIT-UNAM No. IA201617. Financial support for language editing was provided by the Instituto de Ciencias del Mar y Limnología (UNAM). 
Biogeosciences Discuss., https://doi.org/10.5194/bg-2018-279

Manuscript under review for journal Biogeosciences

Discussion started: 14 June 2018

(c) Author(s) 2018. CC BY 4.0 License.

\section{References}

Abell, G., Revill, A. T., Smith, C., Bissett, A. P., Volkman, J. K. and Robert, S. S.: Archaeal ammonia oxidizers and nirStype denitrifiers dominate sediment nitrifying and denitrifying populations in a subtropical macrotidal estuary, ISME J., 4(2), 286-300, doi:10.1038/ismej.2009.105, 2010.

5 Abell, G., Ross, D., Keane, J., Oakes, J., Eyre, B., Robert, S. and Volkman, J.: Nitrifying and denitrifying microbial communities and their relationship to nutrient fluxes and sediment geochemistry in the Derwent Estuary, Tasmania, Aquat. Microb. Ecol., 70(1), 63-75, doi:10.3354/ame01642, 2013.

Adhitya, A., Thomas, F. I. M. and Ward, B. B.: Diversity of assimilatory nitrate reductase genes from plankton and epiphytes associated with a seagrass bed, Microb. Ecol., 54(4), 587-597, doi:10.1007/s00248-006-9175-0, 2007.

10 Agogué, H., Brink, M., Dinasquet, J. and Herndl, G. J.: Major gradients in putatively nitrifying and non-nitrifying Archaea in the deep North Atlantic, Nature, 456(7223), 788-791, doi:10.1038/nature07535, 2008.

Allen, A. E., Booth, M. G., Frischer, M. E., Verity, P. G., Zehr, J. P. and Zani, S.: Diversity and detection of nitrate assimilation genes in marine bacteria, Appl. Environ. Microbiol., 67(11), 5343-5348, doi:10.1128/AEM.67.11.5343$5348.2001,2001$

15 Allen, A. E., Booth, M., Verity, P. and Frischer, M.: Influence of nitrate availability on the distribution and abundance of heterotrophic bacterial nitrate assimilation genes in the Barents Sea during summer, Aquat. Microb. Ecol., 39(3), 247-255, doi:10.3354/ame039247, 2005.

Arp, D. J., Chain, P. S. G. and Klotz, M. G.: The impact of genome analyses on our understanding of ammonia-oxidizing bacteria, Annu. Rev. Microbiol., 61(1), 503-528, doi:10.1146/annurev.micro.61.080706.093449, 2007.

20 Babbin, A. R., Bianchi, D., Jayakumar, A. and Ward, B. B.: Rapid nitrous oxide cycling in the suboxic ocean, Science, 348(6239), 1127-1129, doi:10.1126/science.aaa8380, 2015.

Bale, N. J., Villanueva, L., Fan, H., Stal, L. J., Hopmans, E. C., Schouten, S. and Sinninghe Damsté, J. S.: Occurrence and activity of anammox bacteria in surface sediments of the southern North Sea, FEMS Microbiol. Ecol., 89(1), 99-110, doi:10.1111/1574-6941.12338, 2014.

25 Beman, J. M. and Francis, C. A.: Diversity of ammonia-oxidizing archaea and bacteria in the sediments of a hypernutrified subtropical estuary: Bahía del Tóbari, Mexico, Appl. Environ. Microbiol., 72(12), 7767-7777, doi:10.1128/AEM.00946$06,2006$.

Beman, J. M., Roberts, K. J., Wegley, L., Rohwer, F. and Francis, C. A.: Distribution and diversity of archaeal ammonia monooxygenase genes associated with corals, Appl. Environ. Microbiol., 73(17), 5642-5647, doi:10.1128/AEM.00461-07, 2007

Beman, J. M., Popp, B. N. and Francis, C. A.: Molecular and biogeochemical evidence for ammonia oxidation by marine Crenarchaeota in the Gulf of California, ISME J., 2(4), 429-441, doi:10.1038/ismej.2007.118, 2008.

Beman, J. M., Chow, C.-E., King, A. L., Feng, Y., Fuhrman, J. a, Andersson, A., Bates, N. R., Popp, B. N. and Hutchins, D. 
Biogeosciences Discuss., https://doi.org/10.5194/bg-2018-279

Manuscript under review for journal Biogeosciences

Discussion started: 14 June 2018

(c) Author(s) 2018. CC BY 4.0 License.

A.: Global declines in oceanic nitrification rates as a consequence of ocean acidification, Proc. Natl. Acad. Sci., 108(1), 208-213, doi:10.1073/pnas.1011053108, 2011.

Beman, J. M., Popp, B. N. and Alford, S. E.: Quantification of ammonia oxidation rates and ammonia-oxidizing archaea and bacteria at high resolution in the Gulf of California and eastern tropical North Pacific Ocean, Limnol. Oceanogr., 57(3),

5 711-726, doi:10.4319/lo.2012.57.3.0711, 2012.

Bentzon-Tilia, M., Traving, S. J., Mantikci, M., Knudsen-Leerbeck, H., Hansen, J. L. S., Markager, S. and Riemann, L.: Significant $\mathrm{N}_{2}$ fixation by heterotrophs, photoheterotrophs and heterocystous cyanobacteria in two temperate estuaries, ISME J., 9(2), 273-285, doi:10.1038/ismej.2014.119, 2015.

van den Berg, E. M., Rombouts, J. L., Kuenen, J. G., Kleerebezem, R. and van Loosdrecht, M. C. M.: Role of nitrite in the

10 competition between denitrification and DNRA in a chemostat enrichment culture, AMB Express, 7(1), 91, doi:10.1186/s13568-017-0398-x, 2017.

Berman-Frank, I., Cullen, J. T., Shaked, Y., Sherrell, R. M. and Falkowski, P. G.: Iron availability, cellular iron quotas, and nitrogen fixation in Trichodesmium, Limnol. Oceanogr., 46(6), 1249-1260, doi:10.4319/lo.2001.46.6.1249, $2001 \mathrm{a}$.

Berman-Frank, I., Lundgren, P., Chen, Y.-B., Küpper, H., Kolber, Z., Bergman, B. and Falkowski, P.: Segregation of

15 nitrogen fixation and oxygenic photosynthesis in the marine cyanobacterium Trichodesmium, Science, 294(5546), 15341537, doi:10.1126/science.1064082, 2001b.

Bernhard, A. E., Donn, T., Giblin, A. E. and Stahl, D. A.: Loss of diversity of ammonia-oxidizing bacteria correlates with increasing salinity in an estuary system, Environ. Microbiol., 7(9), 1289-1297, doi:10.1111/j.1462-2920.2005.00808.x, 2005.

20 Bernhard, A. E., Landry, Z. C., Blevins, A., de la Torre, J. R., Giblin, A. E. and Stahl, D. A.: Abundance of ammoniaoxidizing archaea and bacteria along an estuarine salinity gradient in relation to potential nitrification rates, Appl. Environ. Microbiol., 76(4), 1285-1289, doi:10.1128/AEM.02018-09, 2010.

Bertagnolli, A. D. and Ulloa, O.: Hydrography shapes community composition and diversity of amoA-containing Thaumarchaeota in the coastal waters off central Chile, Environ. Microbiol. Rep., 9(6), 717-728, doi:10.1111/1758-

$252229.12579,2017$.

Bonnet, S., Biegala, I. C., Dutrieux, P., Slemons, L. O., and Douglas D. G.: Nitrogen fixation in the western equatorial Pacific: Rates, diazotrophic cyanobacterial size class distribution and biogeochemical significance, Global Biogeochem. Cycles, 23, GB3012, doi:10.1029/2008GB003439, 2009

Böttjer, D., Karl, D. M., Letelier, R. M., Viviani, D. A. and Church, M. J.: Experimental assessment of diazotroph responses

30 to elevated seawater $\mathrm{pCO}_{2}$ in the North Pacific Subtropical Gyre, Global Biogeochem. Cycles, 28(6), 601-616, doi:10.1002/2013GB004690, 2014.

Bourbonnais, A., Juniper, S. K., Butterfield, D. A., Anderson, R. E. and Lehmann, M. F.: Diversity and abundance of bacteria and nirS-encoding denitrifiers associated with the Juan de Fuca Ridge hydrothermal system, Ann. Microbiol., 64(4), 1691-1705, doi:10.1007/s13213-014-0813-3, 2014. 
Biogeosciences Discuss., https://doi.org/10.5194/bg-2018-279

Manuscript under review for journal Biogeosciences

Discussion started: 14 June 2018

(c) Author(s) 2018. CC BY 4.0 License.

Bouskill, N. J., Eveillard, D., Chien, D., Jayakumar, A. and Ward, B. B.: Environmental factors determining ammoniaoxidizing organism distribution and diversity in marine environments, Environ. Microbiol., 14(3), 714-729, doi:10.1111/j.1462-2920.2011.02623.x, 2012.

Bowles, M. W., Nigro, L. M., Teske, A. P. and Joye, S. B.: Denitrification and environmental factors influencing nitrate 5 removal in Guaymas Basin hydrothermally altered sediments, Front. Microbiol., 3, doi:10.3389/fmicb.2012.00377, 2012.

Braker, G. and Tiedje, J. M.: Nitric oxide reductase (norB) genes from pure cultures and environmental samples, Appl. Environ. Microbiol., 69(6), 3476-3483, doi:10.1128/AEM.69.6.3476-3483.2003, 2003.

Braker, G., Zhou, J., Wu, L., Devol, A. H. and Tiedje, J. M.: Nitrite reductase genes (nirK and nirS) as functional markers to investigate diversity of denitrifying bacteria in Pacific Northwest marine sediment communities, Appl. Environ.

10 Microbiol., 66(5), 2096-2104, doi:10.1128/AEM.66.5.2096-2104.2000, 2000.

Brandsma, J., van de Vossenberg, J., Risgaard-Petersen, N., Schmid, M. C., Engström, P., Eurenius, K., Hulth, S., Jaeschke, A., Abbas, B., Hopmans, E. C., Strous, M., Schouten, S., Jetten, M. S. M. and Damsté, J. S. S.: A multi-proxy study of anaerobic ammonium oxidation in marine sediments of the Gullmar Fjord, Sweden, Environ. Microbiol. Rep., 3(3), 360 366, doi:10.1111/j.1758-2229.2010.00233.x, 2011.

15 Breitbarth, E., Oschlies, A. and LaRoche, J.: Physiological constraints on the global distribution of Trichodesmium - effect of temperature on diazotrophy, Biogeosciences, 4(1), 53-61, doi:10.5194/bg-4-53-2007, 2007.

Brin, L. D., Giblin, A. E. and Rich, J. J.: Environmental controls of anammox and denitrification in southern New England estuarine and shelf sediments, Limnol. Oceanogr., 59(3), 851-860, doi:10.4319/lo.2014.59.3.0851, 2014.

Bu, C., Wang, Y., Ge, C., Ahmad, H. A., Gao, B. and Ni, S.-Q.: Dissimilatory nitrate reduction to ammonium in the Yellow River Estuary: rates, abundance, and community diversity, Sci. Rep., 7(1), 6830, doi:10.1038/s41598-017-06404-8, 2017.

Burgin, A. J. and Hamilton, S. K.: Have we overemphasized the role of denitrification in aquatic ecosystems? A review of nitrate removal pathways, Front. Ecol. Environ., 5(2), 89-96, doi:10.1890/1540-9295(2007)5[89:HWOTRO]2.0.CO;2, 2007.

Byrne, N., Strous, M., Crépeau, V., Kartal, B., Birrien, J.-L., Schmid, M., Lesongeur, F., Schouten, S., Jaeschke, A., Jetten,

25 M., Prieur, D. and Godfroy, A.: Presence and activity of anaerobic ammonium-oxidizing bacteria at deep-sea hydrothermal vents, ISME J., 3(1), 117-123, doi:10.1038/ismej.2008.72, 2009.

Caffrey, J. M., Bano, N., Kalanetra, K. and Hollibaugh, J. T.: Ammonia oxidation and ammonia-oxidizing bacteria and archaea from estuaries with differing histories of hypoxia, ISME J., 1(7), 660-662, doi:10.1038/ismej.2007.79, 2007.

Cai, H. and Jiao, N.: Diversity and abundance of nitrate assimilation genes in the northern South China Sea, Microb. Ecol., 30 56(4), 751-764, doi:10.1007/s00248-008-9394-7, 2008.

Cao, H., Hong, Y., Li, M. and Gu, J.-D.: Lower abundance of ammonia-oxidizing archaea than ammonia-oxidizing bacteria detected in the dubsurface sediments of the northern South China Sea, Geomicrobiol. J., 29(4), 332-339, doi:10.1080/01490451.2011.559304, 2012.

Cao, H., Shao, Z., Li, J., Zhang, W. and Qian, P.-Y.: Phylogenetic diversity of nitrogen-utilizing genes in hydrothermal 
Biogeosciences Discuss., https://doi.org/10.5194/bg-2018-279

Manuscript under review for journal Biogeosciences

Discussion started: 14 June 2018

(c) Author(s) 2018. CC BY 4.0 License.

Capone, D. G., O'Neill, J. M., Zehr, J. and Carpenter, E. J.: Basis for diel variation in nitrogenase activity in the marine

5 planktonic cyanobacterium Trichodesmium thiebautti, Appl. Environ. Microbiol., 56(11), 3532-3536, 1990.

Capone, D., Subramaniam, A., Montoya, J., Voss, M., Humborg, C., Johansen, A., Siefert, R. and Carpenter, E.: An extensive bloom of the $\mathrm{N}_{2}$-fixing cyanobacterium Trichodesmium erythraeum in the central Arabian Sea, Mar. Ecol. Prog. Ser., 172, 281-292, doi:10.3354/meps172281, 1998.

Capone, D. G., Burns, J. A., Montoya, J. P., Subramaniam, A., Mahaffey, C., Gunderson, T., Michaels, A. F. and Carpenter,

10 E. J.: Nitrogen fixation by Trichodesmium spp.: An important source of new nitrogen to the tropical and subtropical North Atlantic Ocean, Global Biogeochem. Cycles, 19(2), GB2024, doi:10.1029/2004GB002331, 2005.

Caranto, J. D. and Lancaster, K. M.: Nitric oxide is an obligate bacterial nitrification intermediate produced by hydroxylamine oxidoreductase, Proc. Natl. Acad. Sci., 114(31), 8217-8222, doi:10.1073/pnas.1704504114, 2017.

Cardoso, J., van Bleijswijk, J., Witte, H. and van Duyl, F.: Diversity and abundance of ammonia-oxidizing archaea and

15 bacteria in tropical and cold-water coral reef sponges, Aquat. Microb. Ecol., 68(3), 215-230, doi:10.3354/ame01610, 2013.

Casciotti, K. L. and Ward, B. B.: Phylogenetic analysis of nitric oxide reductase gene homologues from aerobic ammoniaoxidizing bacteria, FEMS Microbiol. Ecol., 52(2), 197-205, doi:10.1016/j.femsec.2004.11.002, 2005.

Castro-González, M., Braker, G., Farias, L. and Ulloa, O.: Communities of nirS-type denitrifiers in the water column of the oxygen minimum zone in the eastern South Pacific, Environ. Microbiol., 7(9), 1298-1306, doi:10.1111/j.1462-

$20 \quad 2920.2005 .00809 . x, 2005$.

Castro-González, M., Molina, V., Rodríguez-Rubio, E. and Ulloa, O.: The first report of a microdiverse anammox bacteria community in waters of Colombian Pacific, a transition area between prominent oxygen minimum zones of the eastern tropical Pacific, Environ. Microbiol. Rep., 6(6), 595-604, doi:10.1111/1758-2229.12165, 2014.

Castro-González, M., Ulloa, O. and Farías, L.: Structure of denitrifying communities reducing $\mathrm{N}_{2} \mathrm{O}$ at suboxic waters off 25 northern Chile and Perú, Rev. Biol. Mar. Oceanogr., 50(1), 95-110, doi:10.4067/S0718-19572015000100008, 2015.

Chen, J., Zhou, Z. and Gu, J.-D.: Complex community of nitrite-dependent anaerobic methane oxidation bacteria in coastal sediments of the Mai Po wetland by PCR amplification of both 16S rRNA and pmoA genes, Appl. Microbiol. Biotechnol., 99(3), 1463-1473, doi:10.1007/s00253-014-6051-6, 2015.

Christman, G. D., Cottrell, M. T., Popp, B. N., Gier, E. and Kirchman, D. L.: Abundance, diversity, and activity of

30 ammonia-oxidizing prokaryotes in the coastal arctic ocean in summer and winter, Appl. Environ. Microbiol., 77(6), 20262034, doi:10.1128/AEM.01907-10, 2011.

Chronopoulou, P.-M., Shelley, F., Pritchard, W. J., Maanoja, S. T. and Trimmer, M.: Origin and fate of methane in the Eastern Tropical North Pacific oxygen minimum zone, ISME J., 11(6), 1386-1399, doi:10.1038/ismej.2017.6, 2017.

Church, M. J., Björkman, K. M., Karl, D. M., Saito, M. A. and Zehr, J. P.: Regional distributions of nitrogen-fixing bacteria 
Biogeosciences Discuss., https://doi.org/10.5194/bg-2018-279

Manuscript under review for journal Biogeosciences

Discussion started: 14 June 2018

(c) Author(s) 2018. CC BY 4.0 License.

Church, M. J., Wai, B., Karl, D. M. and DeLong, E. F.: Abundances of crenarchaeal amoA genes and transcripts in the Pacific Ocean, Environ. Microbiol., 12(3), 679-688, doi:10.1111/j.1462-2920.2009.02108.x, 2010.

Coates, C. J. and Wyman, M.: A denitrifying community associated with a major marine nitrogen fixer, Environ. Microbiol., 5 19(12), 4978-4992, doi:10.1111/1462-2920.14007, 2017.

De Corte, D., Yokokawa, T., Varela, M. M., Agogué, H. and Herndl, G. J.: Spatial distribution of bacteria and archaea and amoA gene copy numbers throughout the water column of the Eastern Mediterranean Sea, ISME J., 3(2), 147-158, doi:10.1038/ismej.2008.94, 2009.

Costa, E., Pérez, J. and Kreft, J.-U.: Why is metabolic labour divided in nitrification?, Trends Microbiol., 14(5), 213-219, 10 doi:10.1016/j.tim.2006.03.006, 2006.

Codispoti, L. A., Brandes, J. A., Christensen, J. P., Devol, A. H., Naqvi, S. W. A., Paerl, H. W. and Yoshinari, T.: The oceanic fixed nitrogen and nitrous oxide budgets: Moving targets as we enter the anthropocene?, Sci. Mar., 65(S2), 85105, doi:10.3989/scimar.2001.65s285, 2001.

Daims, H., Lebedeva, E. V, Pjevac, P., Han, P., Herbold, C., Albertsen, M., Jehmlich, N., Palatinszky, M., Vierheilig, J.,

15 Bulaev, A., Kirkegaard, R. H., von Bergen, M., Rattei, T., Bendinger, B., Nielsen, P. H. and Wagner, M.: Complete nitrification by Nitrospira bacteria, Nature, 528(7583), 504-509, doi:10.1038/nature16461, 2015.

Dale, O. R., Tobias, C. R. and Song, B.: Biogeographical distribution of diverse anaerobic ammonium oxidizing (anammox) bacteria in Cape Fear River Estuary, Environ. Microbiol., 11(5), 1194-1207, doi:10.1111/j.1462-2920.2008.01850.x, 2009.

Dalsgaard, T., Canfield, D. E., Petersen, J., Thamdrup, B. and Acuña-González, J.: $\mathrm{N}_{2}$ production by the anammox reaction 20 in the anoxic water column of Golfo Dulce, Costa Rica, Nature, 422(6932), 606-608, doi:10.1038/nature01526, 2003.

Dalsgaard, T., Thamdrup, B. and Canfield, D. E.: Anaerobic ammonium oxidation (anammox) in the marine environment, Res. Microbiol., 156(4), 457-464, doi:10.1016/j.resmic.2005.01.011, 2005.

Dalsgaard, T., Stewart, F. J., Thamdrup, B., De Brabandere, L., Revsbech, N. P., Ulloa, O., Canfield, D. E. and DeLong, E. F.: Oxygen at nanomolar levels reversibly suppresses process rates and gene expression in anammox and denitrification in

25 the oxygen minimum zone off northern Chile, MBio, 5(6), e01966-14, doi:10.1128/mBio.01966-14, 2014.

Damashek, J. and Francis, C. A.: Microbial nitrogen cycling in estuaries: From genes to ecosystem processes, Estuaries and Coasts, 41(3), 626-660, doi:10.1007/s12237-017-0306-2, 2017.

Dang, H., Zhang, X., Sun, J., Li, T., Zhang, Z. and Yang, G.: Diversity and spatial distribution of sediment ammoniaoxidizing crenarchaeota in response to estuarine and environmental gradients in the Changjiang Estuary and East China

30 Sea, Microbiology, 154(7), 2084-2095, doi:10.1099/mic.0.2007/013581-0, 2008.

Dang, H., Li, J., Zhang, X., Li, T., Tian, F. and Jin, W.: Diversity and spatial distribution of amoA-encoding archaea in the deep-sea sediments of the tropical West Pacific Continental Margin, J. Appl. Microbiol., 106(5), 1482-1493, doi:10.1111/j.1365-2672.2008.04109.x, 2009a.

Dang, H., Luan, X., Zhao, J. and Li, J.: Diverse and novel nifH and nifH-like gene sequences in the deep-sea methane seep 
Biogeosciences Discuss., https://doi.org/10.5194/bg-2018-279

Manuscript under review for journal Biogeosciences

Discussion started: 14 June 2018

(c) Author(s) 2018. CC BY 4.0 License.

5 Dang, H., Zhou, H., Zhang, Z., Yu, Z., Hua, E., Liu, X. and Jiao, N.: Molecular detection of Candidatus Scalindua pacifica and environmental responses of sediment anammox bacterial community in the Bohai Sea, China, PLoS One, 8(4), e61330, doi:10.1371/journal.pone.0061330, 2013.

Decleyre, H., Heylen, K., Van Colen, C. and Willems, A.: Dissimilatory nitrogen reduction in intertidal sediments of a temperate estuary: small scale heterogeneity and novel nitrate-to-ammonium reducers, Front. Microbiol., 6, 1124,

10 doi:10.3389/fmicb.2015.01124, 2015.

Dekas, A. E., Poretsky, R. S. and Orphan, V. J.: Deep-sea archaea fix and share nitrogen in methane-consuming microbial consortia, Science, 326(5951), 422-426, doi:10.1126/science.1178223, 2009.

Dekas, A. E., Chadwick, G. L., Bowles, M. W., Joye, S. B. and Orphan, V. J.: Spatial distribution of nitrogen fixation in methane seep sediment and the role of the ANME archaea, Environ. Microbiol., 16(10), 3012-3029, doi:10.1111/1462-

$15 \quad 2920.12247,2014$.

Devol, A. H.: Denitrification, anammox, and $\mathrm{N}_{2}$ production in marine sediments, Ann. Rev. Mar. Sci., 7(1), 403-423, doi:10.1146/annurev-marine-010213-135040, 2015.

Diaz, R. J. and Rosenberg, R.: Spreading dead zones and consequences for marine ecosystems, Science, 321(5891), 926929, doi:10.1126/science.1156401, 2008.

20 Dong, L. F., Smith, C. J., Papaspyrou, S., Stott, A., Osborn, A. M. and Nedwell, D. B.: Changes in benthic denitrification, nitrate ammonification, and anammox process rates and nitrate and nitrite reductase gene abundances along an estuarine nutrient gradient (the Colne Estuary, United Kingdom), Appl. Environ. Microbiol., 75(10), 3171-3179, doi:10.1128/AEM.02511-08, 2009.

Duce, R. A., LaRoche, J., Altieri, K., Arrigo, K. R., Baker, A. R., Capone, D. G., Cornell, S., Dentener, F., Galloway, J., 25 Ganeshram, R. S., Geider, R. J., Jickells, T., Kuypers, M. M., Langlois, R., Liss, P. S., Liu, S. M., Middelburg, J. J., Moore, C. M., Nickovic, S., Oschlies, A., Pedersen, T., Prospero, J., Schlitzer, R., Seitzinger, S., Sorensen, L. L., Uematsu, M., Ulloa, O., Voss, M., Ward, B. and Zamora, L.: Impacts of atmospheric anthropogenic nitrogen on the open ocean, Science, 320(5878), 893-897, doi:10.1126/science.1150369, 2008.

Dybas, C. L.: Dead zones spreading in world oceans, Bioscience, 55(7), 552-557, doi:10.1641/00063568(2005)055[0552:DZSIWO]2.0.CO;2, 2005.

El-Sayed, S. Z., van Dijken, G. L. and Gonzalez-Rodas, G.: Effects of ultraviolet radiation on marine ecosystems, Int. J. Environ. Stud., 51(3), 199-216, doi: 10.1080/00207239608711081, 1996.

Engström, P., Dalsgaard, T., Hulth, S. and Aller, R. C.: Anaerobic ammonium oxidation by nitrite (anammox): Implications for $\mathrm{N}_{2}$ production in coastal marine sediments, Geochim. Cosmochim. Acta, 69(8), 2057-2065, 
Biogeosciences Discuss., https://doi.org/10.5194/bg-2018-279

Manuscript under review for journal Biogeosciences

Discussion started: 14 June 2018

(c) Author(s) 2018. CC BY 4.0 License.

Ettwig, K. F., Butler, M. K., Le Paslier, D., Pelletier, E., Mangenot, S., Kuypers, M. M. M., Schreiber, F., Dutilh, B. E., Zedelius, J., de Beer, D., Gloerich, J., Wessels, H. J. C. T., van Alen, T., Luesken, F., Wu, M. L., van de Pas-Schoonen, K. T., Op den Camp, H. J. M., Janssen-Megens, E. M., Francoijs, K.-J., Stunnenberg, H., Weissenbach, J., Jetten, M. S. M.

5 and Strous, M.: Nitrite-driven anaerobic methane oxidation by oxygenic bacteria, Nature, 464(7288), 543-548, doi:10.1038/nature $08883,2010$.

Eugster, O. and Gruber, N.: A probabilistic estimate of global marine N-fixation and denitrification, Global Biogeochem. Cycles, 26(4), GB4013, doi:10.1029/2012GB004300, 2012.

Falk, S., Hannig, M., Braker, G., Wardenga, R., Köster, M., Jürgens, K. and Gliesche, C.: NirS-containing denitrifier

10 communities in the water column and sediment of the Baltic Sea, Biogeosciences, 3(3), 697-727, doi:10.5194/bgd-3-6972006, 2007.

Falkowski, P. G.: Evolution of the nitrogen cycle and its influence on the biological sequestration of $\mathrm{CO}_{2}$ in the ocean, Nature, 387(6630), 272-275, doi:10.1038/387272a0, 1997.

Fan, H., Bolhuis, H. and Stal, L. J.: Nitrification and nitrifying bacteria in a coastal microbial mat, Front. Microbiol., 6, 1-13,

15 doi:10.3389/fmicb.2015.01367, 2015.Foster, R. A., Subramaniam, A. and Zehr, J. P.: Distribution and activity of diazotrophs in the Eastern Equatorial Atlantic, Environ. Microbiol., 11(4), 741-750, doi:10.1111/j.14622920.2008.01796.x, 2009.

Foster, R. A., Subramaniam, A. and Zehr, J. P.: Distribution and activity of diazotrophs in the Eastern Equatorial Atlantic, Environ. Microbiol., 11(4), 741-750, doi:10.1111/j.1462-2920.2008.01796.x, 2009.

20 Fowler, D., Steadman, C. E., Stevenson, D., Coyle, M., Rees, R. M., Skiba, U. M., Sutton, M. A., Cape, J. N., Dore, A. J., Vieno, M., Simpson, D., Zaehle, S., Stocker, B. D., Rinaldi, M., Facchini, M. C., Flechard, C. R., Nemitz, E., Twigg, M., Erisman, J. W., Butterbach-Bahl, K. and Galloway, J. N.: Effects of global change during the 21 st century on the nitrogen cycle, Atmos. Chem. Phys., 15(24), 13849-13893, doi:10.5194/acp-15-13849-2015, 2015.

Francis, C. A., O’Mullan, G. D. and Ward, B. B.: Diversity of ammonia monooxygenase (amoA) genes across environmental

25 gradients in Chesapeake Bay sediments, Geobiology, 1(2), 129-140, doi:10.1046/j.1472-4669.2003.00010.x, 2003.

Francis, C. A., Roberts, K. J., Beman, J. M., Santoro, A. E. and Oakley, B. B.: Ubiquity and diversity of ammonia-oxidizing archaea in water columns and sediments of the ocean, Proc. Natl. Acad. Sci., 102(41), 14683-14688, doi:10.1073/pnas.0506625102, 2005.

Francis, C. A., O’Mullan, G. D., Cornwell, J. C. and Ward, B. B.: Transitions in nirS-type denitrifier diversity, community

30 composition, and biogeochemical activity along the Chesapeake Bay estuary, Front. Microbiol., 4, 237, doi:10.3389/fmicb.2013.00237, 2013.

Freing, A., Wallace, D. W. R. and Bange, H. W.: Global oceanic production of nitrous oxide, Philos. Trans. R. Soc. B Biol. Sci., 367(1593), 1245-1255, doi:10.1098/rstb.2011.0360, 2012.

Fuchsman, C. A., Staley, J. T., Oakley, B. B., Kirkpatrick, J. B. and Murray, J. W.: Free-living and aggregate-associated 
Biogeosciences Discuss., https://doi.org/10.5194/bg-2018-279

Manuscript under review for journal Biogeosciences

Discussion started: 14 June 2018

(c) Author(s) 2018. CC BY 4.0 License. community of an offshore oxygen deficient zone, Front. Microbiol., 8, 2384, doi:10.3389/fmicb.2017.02384, 2017.

Fulweiler, R. W., Nixon, S. W., Buckley, B. A. and Granger, S. L.: Reversal of the net dinitrogen gas flux in coastal marine 5 sediments, Nature, 448(7150), 180-182, doi:10.1038/nature05963, 2007.

Galán, A., Molina, V., Thamdrup, B., Woebken, D., Lavik, G., Kuypers, M. M. M. and Ulloa, O.: Anammox bacteria and the anaerobic oxidation of ammonium in the oxygen minimum zone off northern Chile, Deep Sea Res. Part II Top. Stud. Oceanogr., 56(16), 1021-1031, doi:10.1016/j.dsr2.2008.09.016, 2009.

Gardner, W. S., McCarthy, M. J., An, S., Sobolev, D., Sell, K. S. and Brock, D.: Nitrogen fixation and dissimilatory nitrate

10 reduction to ammonium (DNRA) support nitrogen dynamics in Texas estuaries, Limnol. Oceanogr., 51(1), 558-568, doi:10.4319/1o.2006.51.1_part_2.0558, 2006.

Giblin, A. E., Weston, N. B., Banta, G. T., Tucker, J. and Hopkinson, C. S.: The effects of salinity on nitrogen losses from an oligohaline estuarine sediment, Estuaries and Coasts, 33(5), 1054-1068, doi:10.1007/s12237-010-9280-7, 2010.

Glibert, P. M., Wilkerson, F. P., Dugdale, R. C., Raven, J. A., Dupont, C. L., Leavitt, P. R., Parker, A. E., Burkholder, J. M.

15 and Kana, T. M.: Pluses and minuses of ammonium and nitrate uptake and assimilation by phytoplankton and implications for productivity and community composition, with emphasis on nitrogen-enriched conditions, Limnol. Oceanogr., 61(1), 165-197, doi:10.1002/lno.10203, 2016.

Glud, R. N., Grossart, H.-P., Larsen, M., Tang, K. W., Arendt, K. E., Rysgaard, S., Thamdrup, B. and Gissel Nielsen, T.: Copepod carcasses as microbial hot spots for pelagic denitrification, Limnol. Oceanogr., 60(6), 2026-2036, doi:10.1002/lno.10149, 2015

Goebel, N. L., Turk, K. A., Achilles, K. M., Paerl, R., Hewson, I., Morrison, A. E., Montoya, J. P., Edwards, C. A. and Zehr, J. P.: Abundance and distribution of major groups of diazotrophic cyanobacteria and their potential contribution to $\mathrm{N}_{2}$ fixation in the tropical Atlantic Ocean, Environ. Microbiol., 12(12), 3272-3289, doi:10.1111/j.1462-2920.2010.02303.x, 2010.

25 Gradoville, M. R., Bombar, D., Crump, B. C., Letelier, R. M., Zehr, J. P. and White, A. E.: Diversity and activity of nitrogen-fixing communities across ocean basins, Limnol. Oceanogr., 62(5), 1895-1909, doi:10.1002/lno.10542, 2017.

Graf, D. R. H., Jones, C. M. and Hallin, S.: Intergenomic comparisons highlight modularity of the denitrification pathway and underpin the importance of community structure for $\mathrm{N}_{2} \mathrm{O}$ emissions, PLoS One, 9(12), e114118, doi:10.1371/journal.pone.0114118, 2014.

30 Granger, J. and Ward, B. B.: Accumulation of nitrogen oxides in copper-limited cultures of denitrifying bacteria, Limnol. Oceanogr., 48(1), 313-318, doi:10.4319/1o.2003.48.1.0313, 2003.

Gruber, N.: The marine nitrogen cycle: Overviews and challenges, in Nitrogen in the Marine Environment, pp. 1-50, Elsevier., 2008.

Gruber, N.: Elusive marine nitrogen fixation, Proc. Natl. Acad. Sci., 113(16), 4246-4248, doi:10.1073/pnas.1603646113, 
Biogeosciences Discuss., https://doi.org/10.5194/bg-2018-279

Manuscript under review for journal Biogeosciences

Discussion started: 14 June 2018

(c) Author(s) 2018. CC BY 4.0 License.

2016.

Gruber, N. and Galloway, J.: An Earth-system perspective of the global nitrogen cycle, Nature, 451(7176), 293-296, doi:10.1038/nature06592, 2008.

Guerinot, M. L. and Colwell, R. R.: Enumeration, isolation, and characterization of $\mathrm{N}_{2}$-fixing bacteria from seawater, Appl.

5 Environ. Microbiol., 50(2), 350-355, 1985.

Hamersley, M. R., Lavik, G., Woebken, D., Rattray, J. E., Lam, P., Hopmans, E. C., Damsté, J. S. S., Krüger, S., Graco, M., Gutiérrez, D. and Kuypers, M. M. M.: Anaerobic ammonium oxidation in the Peruvian oxygen minimum zone , Limnol. Ocean., 52(3), 923-933, doi:10.4319/10.2007.52.3.0923, 2007.

Hamersley, M. R., Turk, K. A., Leinweber, A., Gruber, N., Zehr, J. P., Gunderson, T. and Capone, D. G.: Nitrogen fixation

10 within the water column associated with two hypoxic basins in the Southern California Bight, Aquat. Microb. Ecol., 63(2), 193-205, doi:10.3354/ame01494, 2011.

Han, P., Klümper, U., Wong, A., Li, M., Lin, J. G., Quan, Z., Denecke, M. and Gu, J. D.: Assessment of molecular detection of anaerobic ammonium-oxidizing (anammox) bacteria in different environmental samples using PCR primers based on 16S rRNA and functional genes, Appl. Microbiol. Biotechnol., 101(20), 7689-7702, doi:10.1007/s00253-017-8502-3, $15 \quad 2017$

Hannig, M., Braker, G., Dippner, J. and Jürgens, K.: Linking denitrifier community structure and prevalent biogeochemical parameters in the pelagial of the central Baltic Proper (Baltic Sea), FEMS Microbiol. Ecol., 57(2), 260-271, doi:10.1111/j.1574-6941.2006.00116.x, 2006.

Harhangi, H. R., Le Roy, M., van Alen, T., Hu, B. lan, Groen, J., Kartal, B., Tringe, S. G., Quan, Z. X., Jetten, M. S. M. and

20 Op den Camp, H. J. M.: Hydrazine synthase, a unique phylomarker with which to study the presence and biodiversity of anammox bacteria, Appl. Environ. Microbiol., 78(3), 752-758, doi:10.1128/AEM.07113-11, 2012.

Haroon, M. F., Hu, S., Shi, Y., Imelfort, M., Keller, J., Hugenholtz, P., Yuan, Z. and Tyson, G. W.: Anaerobic oxidation of methane coupled to nitrate reduction in a novel archaeal lineage, Nature, 500(7464), 567-570, doi:10.1038/nature12375, 2013.

25 Hino, T., Matsumoto, Y., Nagano, S., Sugimoto, H., Fukumori, Y., Murata, T., Iwata, S. and Shiro, Y.: Structural basis of biological $\mathrm{N}_{2} \mathrm{O}$ generation by bacterial nitric oxide reductase, Science., 330(6011), 1666-1670, doi:10.1126/science.1195591, 2010

Hirsch, M. D., Long, Z. T. and Song, B.: Anammox bacterial diversity in various aquatic ecosystems based on the detection of hydrazine oxidase genes (hzoA/hzoB), Microb. Ecol., 61(2), 264-276, doi:10.1007/s00248-010-9743-1, 2011.

30 Holl, C. M. and Montoya, J. P.: Interactions between nitrate uptake and nitrogen fixation in continuous cultures of the marine diazotroph Trichodesmuium (Cyanobacteria), J. Phycol., 41(6), 1178-1183, doi:10.1111/j.15298817.2005.00146.x, 2005.

Holl, C. M., Waite, A. M., Pesant, S., Thompson, P. A. and Montoya, J. P.: Unicellular diazotrophy as a source of nitrogen to Leeuwin Current coastal eddies, Deep Sea Res. Part II Top. Stud. Oceanogr., 54(8-10), 1045-1054, 
Biogeosciences Discuss., https://doi.org/10.5194/bg-2018-279

Manuscript under review for journal Biogeosciences

Discussion started: 14 June 2018

(c) Author(s) 2018. CC BY 4.0 License.

Hong, Y.-G., Li, M., Cao, H. and Gu, J.-D.: Residence of habitat-specific anammox bacteria in the deep-sea subsurface sediments of the South China Sea: analyses of marker gene abundance with physical chemical parameters, Microb. Ecol., 62(1), 36-47, doi:10.1007/s00248-011-9849-0, 2011a.

5 Hong, Y.-G., Yin, B. and Zheng, T. L.: Diversity and abundance of anammox bacterial community in the deep-ocean surface sediment from equatorial Pacific, Appl. Microbiol. Biotechnol., 89(4), 1233-1241, doi:10.1007/s00253-010-2925-4, $2011 \mathrm{~b}$.

Horak, R. E. A., Qin, W., Schauer, A. J., Armbrust, E. V., Ingalls, A. E., Moffett, J. W., Stahl, D. A. and Devol, A. H.: Ammonia oxidation kinetics and temperature sensitivity of a natural marine community dominated by archaea, ISME J.,

10 7(10), 2023-2033, doi:10.1038/ismej.2013.75, 2013.

Hou, L., Zheng, Y., Liu, M., Gong, J., Zhang, X., Yin, G. and You, L.: Anaerobic ammonium oxidation (anammox) bacterial diversity, abundance, and activity in marsh sediments of the Yangtze Estuary, J. Geophys. Res. Biogeosciences, 118(3), 1237-1246, doi:10.1002/jgrg.20108, 2013.

Howarth, R. W., Marino, R., Lane, J., Cole, J. J. and Howarth R. Marino, J. Lane, and J. J. Cole., R. W.: Nitrogen fixation in

15 freshwater, estuarine, and marine ecosystems. 1. Rates and importance, Limnol. Oceanogr., 33(4), 669-687, doi:10.4319/10.1988.33.4part2.0669, 1988.

Hutchins, D., Mulholland, M. and Fu, F.: Nutrient cycles and marine microbes in a $\mathrm{CO}_{2}$-enriched ocean, Oceanography, 22(4), 128-145, doi:10.5670/oceanog.2009.103, 2009.

Hutchins, D. A. and Fu, F.: Microorganisms and ocean global change., Nat. Microbiol., 2(6), 17058, 20 doi:10.1038/nmicrobiol.2017.58, 2017.

Hutchins, D. A., Fu, F.-X., Zhang, Y., Warner, M. E., Feng, Y., Portune, K., Bernhardt, P. W. and Mulholland, M. R.: $\mathrm{CO}_{2}$ control of Trichodesmium $\mathrm{N}_{2}$ fixation, photosynthesis, growth rates, and elemental ratios: Implications for past, present, and future ocean biogeochemistry, Limnol. Oceanogr., 52(4), 1293-1304, doi:10.4319/lo.2007.52.4.1293, 2007.

Jaeschke, A., Hopmans, E. C., Wakeham, S. G., Schouten, S. and Sinninghe Damsté, J. S.: The presence of ladderane lipids 25 in the oxygen minimum zone of the Arabian Sea indicates nitrogen loss through anammox, Limnol. Oceanogr., 52(2), 780786, doi:10.4319/1o.2007.52.2.0780, 2007.

Jäntti, H., Stange, F., Leskinen, E. and Hietanen, S.: Seasonal variation in nitrification and nitrate-reduction pathways in coastal sediments in the Gulf of Finland, Baltic Sea, Aquat. Microb. Ecol., 63(2), 171-181, doi:10.3354/ame01492, 2011.

Jayakumar, A., O'Mullan, G. D., Naqvi, S. W. A. A. and Ward, B. B.: Denitrifying bacterial community composition

30 changes associated with stages of denitrification in oxygen minimum zones, Microb. Ecol., 58(2), 350-362, doi:10.1007/s00248-009-9487-y, 2009.

Jayakumar, A., Al-Rshaidat, M. M. D., Ward, B. B. and Mulholland, M. R.: Diversity, distribution, and expression of diazotroph nifH genes in oxygen-deficient waters of the Arabian Sea, FEMS Microbiol. Ecol., 82(3), 597-606, doi:10.1111/j.1574-6941.2012.01430.x, 2012. 
Biogeosciences Discuss., https://doi.org/10.5194/bg-2018-279

Manuscript under review for journal Biogeosciences

Discussion started: 14 June 2018

(c) Author(s) 2018. CC BY 4.0 License.

Jayakumar, D. and Ward, B. B.: Community composition of bacteria involved in fixed nitrogen loss in the water column of two major oxygen minimum zones in the ocean, Aquat. Microb. Ecol., 70(3), 245-259, doi:10.3354/ame01654, 2013.

Jayakumar, D., Francis, C. A., Naqvi, S. W. A. and Ward, B. B.: Diversity of nitrite reductase genes (nirS) in the denitrifying water column of the coastal Arabian Sea, Aquat. Microb. Ecol., 34(1), 69-78, doi:10.3354/ame034069, 2004.

5 Jenkins, B. D., Zehr, J. P., Gibson, A. and Campbell, L.: Cyanobacterial assimilatory nitrate reductase gene diversity in coastal and oligotrophic marine environments, Environ. Microbiol., 8(12), 2083-2095, doi:10.1111/j.14622920.2006.01084.x, 2006

Jensen, M. M., Lam, P., Revsbech, N. P., Nagel, B., Gaye, B., Jetten, M. S. M. and Kuypers, M. M. M.: Intensive nitrogen loss over the Omani Shelf due to anammox coupled with dissimilatory nitrite reduction to ammonium, ISME J., 5(10),

10 1660-1670, doi:10.1038/ismej.2011.44, 2011

Jetten, M. S. M., Niftrik, L. van, Strous, M., Kartal, B., Keltjens, J. T. and Op den Camp, H. J. M.: Biochemistry and molecular biology of anammox bacteria, Crit. Rev. Biochem. Mol. Biol., 44(2-3), 65-84, doi:10.1080/10409230902722783, 2009.

Jiang, X. and Jiao, N.: Vertical distribution of bacterial communities in the indian ocean as revealed by analyses of $16 \mathrm{~S}$

15 rRNA and nasA genes, Indian J. Microbiol., 56(3), 309-317, doi:10.1007/s12088-016-0585-5, 2016.

Jiang, X., Dang, H. and Jiao, N.: Ubiquity and diversity of heterotrophic bacterial nasA genes in diverse marine environments, PLoS One, 10(2), e0117473, doi:10.1371/journal.pone.0117473, 2015.

Jickells, T. D., Buitenhuis, E., Altieri, K., Baker, A. R., Capone, D., Duce, R. A., Dentener, F., Fennel, K., Kanakidou, M., LaRoche, J., Lee, K., Liss, P., Middelburg, J. J., Moore, J. K., Okin, G., Oschlies, A., Sarin, M., Seitzinger, S., Sharples, J.,

20 Singh, A., Suntharalingam, P., Uematsu, M. and Zamora, L. M.: A reevaluation of the magnitude and impacts of anthropogenic atmospheric nitrogen inputs on the ocean, Global Biogeochem. Cycles, 31, 289-305, doi:10.1002/2016GB005586, 2017.

Jin, T., Zhang, T., Ye, L., Lee, O. O., Wong, Y. H. and Qian, P. Y.: Diversity and quantity of ammonia-oxidizing archaea and bacteria in sediment of the Pearl River Estuary, China, Appl. Microbiol. Biotechnol., 90(3), 1137-1145,

25 doi:10.1007/s00253-011-3107-8, 2011.

Jones, C. M., Stres, B., Rosenquist, M. and Hallin, S.: Phylogenetic analysis of nitrite, nitric oxide, and nitrous oxide respiratory enzymes reveal a complex evolutionary history for denitrification, Mol. Biol. Evol., 25(9), 1955-1966, doi:10.1093/molbev/msn146, 2008.

Jones, C. M., Graf, D. R., Bru, D., Philippot, L. and Hallin, S.: The unaccounted yet abundant nitrous oxide-reducing

30 microbial community: a potential nitrous oxide sink, ISME J., 7(2), 417-426, doi:10.1038/ismej.2012.125, 2013.

Kalvelage, T., Jensen, M. M., Contreras, S., Revsbech, N. P., Lam, P., Günter, M., LaRoche, J., Lavik, G. and Kuypers, M. M. M.: Oxygen sensitivity of anammox and coupled N-cycle processes in oxygen minimum zones, PLoS One, 6(12), e29299, doi:10.1371/journal.pone.0029299, 2011.

Kalvelage, T., Lavik, G., Lam, P., Contreras, S., Arteaga, L., Loscher, C. R., Oschlies, A., Paulmier, A., Stramma, L., Kuypers, M. M. M., Löscher, C. R., Oschlies, A., Paulmier, A., Stramma, L. and Kuypers, M. M. M.: Nitrogen cycling 
Biogeosciences Discuss., https://doi.org/10.5194/bg-2018-279

Manuscript under review for journal Biogeosciences

Discussion started: 14 June 2018

(c) Author(s) 2018. CC BY 4.0 License.

Kamp, A., de Beer, D., Nitsch, J. L., Lavik, G. and Stief, P.: Diatoms respire nitrate to survive dark and anoxic conditions, Proc. Natl. Acad. Sci., 108(14), 5649-5654, doi:10.1073/pnas.1015744108, 2011.

5 Kamp, A., Stief, P., Knappe, J. and de Beer, D.: Response of the ubiquitous pelagic diatom Thalassiosira weissflogii to darkness and anoxia, PLoS One, 8(12), e82605, doi:10.1371/journal.pone.0082605, 2013.

Karl, D., Michaels, A., Bergman, B., Capone, D., Carpenter, E., Letelier, R., Lipschultz, F., Paerl, H., Sigman, D. and Stal, L.: Dinitrogen fixation in the world's ocean, Biogeochemistry, 57(1), 47-98, doi:10.1023/A:1015798105851, 2002.

Kartal, B., Maalcke, W. J., de Almeida, N. M., Cirpus, I., Gloerich, J., Geerts, W., Op den Camp, H. J. M., Harhangi, H. R.,

10 Janssen-Megens, E. M., Francoijs, K.-J., Stunnenberg, H. G., Keltjens, J. T., Jetten, M. S. M. and Strous, M.: Molecular mechanism of anaerobic ammonium oxidation, Nature, 479(7371), 127-130, doi:10.1038/nature10453, 2011.

Kartal, B., van Niftrik, L., Keltjens, J. T., Op den Camp, H. J. M. and Jetten, M. S. M.: Anammox—growth physiology, cell biology, and metabolism, in Advances in Microbial Physiology, vol. 60, pp. 211-262, Elsevier Ltd., 2012.

van Kessel, M. A. H. J., Speth, D. R., Albertsen, M., Nielsen, P. H., Op den Camp, H. J. M., Kartal, B., Jetten, M. S. M. and

15 Lücker, S.: Complete nitrification by a single microorganism, Nature, 528(7583), 555-559, doi:10.1038/nature16459, 2015.

Kim, O.-S., Imhoff, J. F., Witzel, K.-P. and Junier, P.: Distribution of denitrifying bacterial communities in the stratified water column and sediment-water interface in two freshwater lakes and the Baltic Sea, Aquat. Ecol., 45(1), 99-112, doi:10.1007/s10452-010-9335-7, 2011.

20 Kits, K. D., Sedlacek, C. J., Lebedeva, E. V., Han, P., Bulaev, A., Pjevac, P., Daebeler, A., Romano, S., Albertsen, M., Stein, L. Y., Daims, H. and Wagner, M.: Kinetic analysis of a complete nitrifier reveals an oligotrophic lifestyle, Nature, 549(7671), 269-272, doi:10.1038/nature23679, 2017.

Kitidis, V., Laverock, B., McNeill, L. C., Beesley, A., Cummings, D., Tait, K., Osborn, M. A. and Widdicombe, S.: Impact of ocean acidification on benthic and water column ammonia oxidation, Geophys. Res. Lett., 38, L21603,

25 doi:10.1029/2011GL049095, 2011.

Knapp, A. N.: The sensitivity of marine $\mathrm{N}_{2}$ fixation to dissolved inorganic nitrogen, Front. Microbiol., 3, 374, doi:10.3389/fmicb.2012.00374, 2012.

Kong, L., Jing, H., Kataoka, T., Buchwald, C. and Liu, H.: Diversity and spatial distribution of hydrazine oxidoreductase (hzo) gene in the oxygen minimum zone off Costa Rica, PLoS One, 8(10), e78275, doi:10.1371/journal.pone.0078275, $30 \quad 2013$

Könneke, M., Bernhard, A. E., de la Torre, J. R., Walker, C. B., Waterbury, J. B. and Stahl, D. A.: Isolation of an autotrophic ammonia-oxidizing marine archaeon, Nature, 437(7058), 543-546, doi:10.1038/nature03911, 2005.

Kraft, B., Tegetmeyer, H. E., Sharma, R., Klotz, M. G., Ferdelman, T. G., Hettich, R. L., Geelhoed, J. S. and Strous, M.: The environmental controls that govern the end product of bacterial nitrate respiration, Science, 345(6197), 676-679, 
Biogeosciences Discuss., https://doi.org/10.5194/bg-2018-279

Manuscript under review for journal Biogeosciences

Discussion started: 14 June 2018

(c) Author(s) 2018. CC BY 4.0 License.

Kuypers, M. M. M.: A division of labour combined, Nature, 528(7583), 487-488, doi:10.1038/528487a, 2015.

Kuypers, M. M. M.: A fight for scraps of ammonia, Nature, 549(7671), 162-163, doi:10.1038/549162a, 2017.

Kuypers, M. M. M., Sliekers, A. O., Lavik, G., Schmid, M., Jørgensen, B. B., Kuenen, J. G., Sinninghe Damsté, J. S., Strous,

5 M. and Jetten, M. S. M.: Anaerobic ammonium oxidation by anammox bacteria in the Black Sea, Nature, 422(6932), 608611, doi:10.1038/nature01472, 2003.

Kuypers, M. M. M., Lavik, G., Woebken, D., Schmid, M., Fuchs, B. M., Amann, R., Jorgensen, B. B. and Jetten, M. S. M.: Massive nitrogen loss from the Benguela upwelling system through anaerobic ammonium oxidation, Proc. Natl. Acad. Sci., 102(18), 6478-6483, doi:10.1073/pnas.0502088102, 2005.

10 Kuypers, M. M. M., Marchant, H. K. and Kartal, B.: The microbial nitrogen-cycling network, Nat. Rev. Microbiol., doi:10.1038/nrmicro.2018.9, 2018.

Lam, P. and Kuypers, M. M. M.: Microbial nitrogen cycling processes in oxygen minimum zones, Ann. Rev. Mar. Sci., 3(1), 317-345, doi:10.1146/annurev-marine-120709-142814, 2011.

Lam, P., Jensen, M. M., Lavik, G., Mcginnis, D. F., Mu, B., Amann, R., Thamdrup, B. B., Kuypers, M. M. M., Muller, B.,

15 Schubert, C. J., Amann, R., Thamdrup, B. B. and Kuypers, M. M. M.: Linking crenarchaeal and bacterial nitrification to anammox in the Black Sea, Proc. Natl. Acad. Sci., 104(17), 7104-7109, doi:10.1073/pnas.0611081104, 2007.

Lam, P., Lavik, G., Jensen, M. M., van de Vossenberg, J., Schmid, M., Woebken, D., Gutierrez, D., Amann, R., Jetten, M. S. M. and Kuypers, M. M. M.: Revising the nitrogen cycle in the Peruvian oxygen minimum zone, Proc. Natl. Acad. Sci., 106(12), 4752-4757, doi:10.1073/pnas.0812444106, 2009.

20 Landolfi, A., Somes, C. J., Koeve, W., Zamora, L. M. and Oschlies, A.: Oceanic nitrogen cycling and $\mathrm{N}_{2} \mathrm{O}$ flux perturbations in the Anthropocene, Global Biogeochem. Cycles, 31(8), 1236-1255, doi:10.1002/2017GB005633, 2017.

Langlois, R. J., LaRoche, J. and Raab, P. A: Diazotrophic diversity and distribution in the tropical and subtropical Atlantic Ocean, Appl. Environ. Microbiol., 71(12), 7910-7919, doi:10.1128/AEM.71.12.7910-7919.2005, 2005.

Langlois, R. J., Hummer, D. and LaRoche, J.: Abundances and distributions of the dominant nifH phylotypes in the Northern

25 Atlantic Ocean, Appl. Environ. Microbiol., 74(6), 1922-1931, doi:10.1128/AEM.01720-07, 2008.

Law, C. S., Breitbarth, E., Hoffmann, L. J., McGraw, C. M., Langlois, R. J., LaRoche, J., Marriner, A. and Safi, K. A.: No stimulation of nitrogen fixation by non-filamentous diazotrophs under elevated $\mathrm{CO}_{2}$ in the South Pacific, Glob. Chang. Biol., 18(10), 3004-3014, doi:10.1111/j.1365-2486.2012.02777.x, 2012.

Lee, J. A. and Francis, C. A.: Deep nirS amplicon sequencing of San Francisco Bay sediments enables prediction of

30 geography and environmental conditions from denitrifying community composition, Environ. Microbiol., 19(12), 48974912, doi:10.1111/1462-2920.13920, 2017.

Lema, K. A., Willis, B. L. and Bourneb, D. G.: Corals form characteristic associations with symbiotic nitrogen-fixing bacteria, Appl. Environ. Microbiol., 78(9), 3136-3144, doi:10.1128/AEM.07800-11, 2012.

Lema, K. A., Willis, B. L. and Bourne, D. G.: Amplicon pyrosequencing reveals spatial and temporal consistency in 
Biogeosciences Discuss., https://doi.org/10.5194/bg-2018-279

Manuscript under review for journal Biogeosciences

Discussion started: 14 June 2018

(c) Author(s) 2018. CC BY 4.0 License.

Li, J. A., Nedwell, D. B., Beddow, J., Dumbrell, A. J., McKew, B. A., Thorpe, E. L. and Whitby, C.: amoA gene abundances and nitrification potential rates suggest that benthic ammonia-oxidizing bacteria and not archaea dominate $\mathrm{N}$ cycling in the

5 Colne Estuary, United Kingdom, Appl. Environ. Microbiol., 81(1), 159-165, doi:10.1128/AEM.02654-14, 2015.

Li, M., Cao, H., Hong, Y.-G. and Gu, J.-D.: Seasonal dynamics of anammox bacteria in estuarial sediment of the Mai Po Nature Reserve revealed by analyzing the 16S rRNA and hydrazine oxidoreductase ( $h z o$ ) genes., Microbes Environ., 26(1), 15-22, doi: 10.1264/jsme2.ME10131, 2011.

Li, M., Hong, Y., Cao, H. and Gu, J.-D.: Community structures and distribution of anaerobic ammonium oxidizing and nirS-

10 encoding nitrite-reducing bacteria in surface sediments of the South China Sea, Microb. Ecol., 66(2), 281-296, doi:10.1007/s00248-012-0175-y, 2013.

Li-dong, S., Qun, Z., Shuai, L., Ping, D., Jiang-ning, Z., Dong-qing, C., Xiang-yang, X., Ping, Z. and Bao-lan, H.: Molecular evidence for nitrite-dependent anaerobic methane-oxidising bacteria in the Jiaojiang estuary of the East Sea (China), Appl. Microbiol. Biotechnol., 98(11), 5029-5038, doi:10.1007/s00253-014-5556-3, 2014.

15 Lisa, J. A., Song, B., Tobias, C. and Duernberger, K.: Impacts of freshwater fluhing on anammox community structure and activities in the New River Estuary, USA, Aquat. Microb. Ecol., 72(1), 17-31, doi:10.3354/ame01682, 2014.

Lisa, J. A., Song, B., Tobias, C. R. and Hines, D. E.: Genetic and biogeochemical investigation of sedimentary nitrogen cycling communities responding to tidal and seasonal dynamics in Cape Fear River Estuary, Estuar. Coast. Shelf Sci., 167, A313-A323, doi:10.1016/j.ecss.2015.09.008, 2015.

20 Liu, X., Tiquia, S. M., Holguin, G., Wu, L., Nold, S. C., Devol, A. H., Luo, K., Palumbo, A. V, Tiedje, J. M. and Zhou, J.: Molecular diversity of denitrifying genes in continental margin sediments within the oxygen-deficient zone off the Pacific coast of Mexico, Appl. Environ. Microbiol., 69(6), 3549-3560, doi:10.1128/AEM.69.6.3549-3560.2003, 2003.

Lledó, B., Marhuenda-Egea, F. C., Martínez-Espinosa, R. M. and Bonete, M. J.: Identification and transcriptional analysis of nitrate assimilation genes in the halophilic archaeon Haloferax mediterranei, Gene, 361(1-2), 80-88, 25 doi:10.1016/j.gene.2005.07.011, 2005.

Lomas, M., Hopkinson, B., Losh, J., Ryan, D., Shi, D., Xu, Y. and Morel, F.: Effect of ocean acidification on cyanobacteria in the subtropical North Atlantic, Aquat. Microb. Ecol., 66(3), 211-222, doi:10.3354/ame01576, 2012.

Luesken, F. A., Sánchez, J., van Alen, T. A., Sanabria, J., Op den Camp, H. J. M., Jetten, M. S. M. and Kartal, B.: Simultaneous nitrite-dependent anaerobic methane and ammonium oxidation processes, Appl. Environ. Microbiol., 77(19), 6802-6807, doi:10.1128/AEM.05539-11, 2011.

Lüke, C., Speth, D. R., Kox, M. A. R., Villanueva, L. and Jetten, M. S. M.: Metagenomic analysis of nitrogen and methane cycling in the Arabian Sea oxygen minimum zone, PeerJ, 4, e1924, doi:10.7717/peerj.1924, 2016.

Luo, H., Tolar, B. B., Swan, B. K., Zhang, C. L., Stepanauskas, R., Ann Moran, M. and Hollibaugh, J. T.: Single-cell genomics shedding light on marine Thaumarchaeota diversification, ISME J., 8(3), 732-736, doi:10.1038/ismej.2013.202, 
Biogeosciences Discuss., https://doi.org/10.5194/bg-2018-279

Manuscript under review for journal Biogeosciences

Discussion started: 14 June 2018

(c) Author(s) 2018. CC BY 4.0 License.

2014.

Luo, Z.-H., Xu, W., Li, M., Gu, J.-D. and Zhong, T.-H.: Spatial distribution and abundance of ammonia-oxidizing microorganisms in deep-sea sediments of the Pacific Ocean, Antonie Van Leeuwenhoek, 108(2), 329-342, doi:10.1007/s10482-015-0485-4, 2015.

5 Magalhães, C. M., Machado, A., Matos, P. and Bordalo, A. A.: Impact of copper on the diversity, abundance and transcription of nitrite and nitrous oxide reductase genes in an urban European estuary, FEMS Microbiol. Ecol., 77(2), 274-284, doi:10.1111/j.1574-6941.2011.01107.x, 2011.

Martínez-García, M., Stief, P., Díaz-Valdés, M., Wanner, G., Ramos-Esplá, A., Dubilier, N. and Antón, J.: Ammoniaoxidizing Crenarchaeota and nitrification inside the tissue of a colonial ascidian, Environ. Microbiol., 10(11), 2991-3001,

10 doi:10.1111/j.1462-2920.2008.01761.x, 2008.

Mazard, S. L., Fuller, N. J., Orcutt, K. M., Bridle, O. and Scanlan, D. J.: PCR analysis of the distribution of unicellular cyanobacterial diazotrophs in the Arabian Sea, Appl. Environ. Microbiol., 70(12), 7355-7364, doi:10.1128/AEM.70.12.7355-7364.2004, 2004

Mehta, M. P. and Baross, J. A.: Nitrogen fixation at $92^{\circ} \mathrm{C}$ by a hydrothermal vent archaeon, Science, 314(5806), 1783-1786, 15 doi:10.1126/science.1134772, 2006

Mehta, M. P., Butterfield, D. A and Baross, J. A: Phylogenetic diversity of nitrogenase (nifH) genes in deep-sea and hydrothermal vent environments of the Juan de Fuca Ridge, Appl. Environ. Microbiol., 69(2), 960-970, doi:10.1128/AEM.69.2.960-970.2003, 2003.

Mincer, T. J., Church, M. J., Taylor, L. T., Preston, C., Karl, D. M. and DeLong, E. F.: Quantitative distribution of

20 presumptive archaeal and bacterial nitrifiers in Monterey Bay and the North Pacific Subtropical Gyre, Environ. Microbiol., 9(5), 1162-1175, doi:10.1111/j.1462-2920.2007.01239.x, 2007.

Miyazaki, J., Higa, R., Toki, T., Ashi, J., Tsunogai, U., Nunoura, T., Imachi, H. and Takai, K.: Molecular characterization of potential nitrogen fixation by anaerobic methane-oxidizing archaea in the methane seep sediments at the number 8 Kumano Knoll in the Kumano Basin, offshore of Japan, Appl. Environ. Microbiol., 75(22), 7153-7162,

25 doi:10.1128/AEM.01184-09, 2009.

Mohamed, N. M., Saito, K., Tal, Y. and Hill, R. T.: Diversity of aerobic and anaerobic ammonia-oxidizing bacteria in marine sponges, ISME J., 4(1), 38-48, doi:10.1038/ismej.2009.84, 2010.

Moisander, P. H., Morrison, A. E., Ward, B. B., Jenkins, B. D. and Zehr, J. P.: Spatial-temporal variability in diazotroph assemblages in Chesapeake Bay using an oligonucleotide nifH microarray, Environ. Microbiol., 9(7), 1823-1835,

30 doi:10.1111/j.1462-2920.2007.01304.x, 2007.

Moisander, P. H., Beinart, R. A., Hewson, I., White, A. E., Johnson, K. S., Carlson, C. A., Montoya, J. P. and Zehr, J. P.: Unicellular cyanobacterial distributions broaden the oceanic $\mathrm{N}_{2}$ fixation domain, Science, 327(5972), 1512-1514, doi:10.1126/science.1185468, 2010.

Molina, V., Belmar, L. and Ulloa, O.: High diversity of ammonia-oxidizing archaea in permanent and seasonal oxygen- 
Biogeosciences Discuss., https://doi.org/10.5194/bg-2018-279

Manuscript under review for journal Biogeosciences

Discussion started: 14 June 2018

(c) Author(s) 2018. CC BY 4.0 License.

Monteiro, F. M., Follows, M. J. and Dutkiewicz, S.: Distribution of diverse nitrogen fixers in the global ocean, Global Biogeochem. Cycles, 24(3), GB3017, doi:10.1029/2009GB003731, 2010.

5 Montoya, J. P., Voss, M. and Capone, D. G.: Spatial variation in $\mathrm{N}_{2}$-fixation rate and diazotroph activity in the tropical Atlantic, Biogeosciences, 4(3), 369-376, doi:10.5194/bg-4-369-2007, 2007.

Moore, C. M., Mills, M. M., Achterberg, E. P., Geider, R. J., LaRoche, J., Lucas, M. I., McDonagh, E. L., Pan, X., Poulton, A. J., Rijkenberg, M. J. A., Suggett, D. J., Ussher, S. J. and Woodward, E. M. S.: Large-scale distribution of Atlantic nitrogen fixation controlled by iron availability, Nat. Geosci., 2(12), 867-871, doi:10.1038/ngeo667, 2009.

10 Moreno-Vivián, C., Cabello, P., Martínez-Luque, M., Blasco, R. and Castillo, F.: Prokaryotic nitrate reduction: molecular properties and functional distinction among bacterial nitrate reductases, J. Bacteriol., 181(21), 6573-84, 1999.

Mosier, A. C. and Francis, C. A.: Relative abundance and diversity of ammonia-oxidizing archaea and bacteria in the San Francisco Bay estuary, Environ. Microbiol., 10(11), 3002-3016, doi:10.1111/j.1462-2920.2008.01764.x, 2008.

Mosier, A. C. and Francis, C. A.: Denitrifier abundance and activity across the San Francisco Bay estuary, Environ.

15 Microbiol. Rep., 2(5), 667-676, doi:10.1111/j.1758-2229.2010.00156.x, 2010.

Mulholland, M. R., Bernhardt, P. W., Blanco-Garcia, J. L., Mannino, A., Hyde, K., Mondragon, E., Turk, K., Moisander, P. H. and Zehr, J. P.: Rates of dinitrogen fixation and the abundance of diazotrophs in North American coastal waters between Cape Hatteras and Georges Bank, Limnol. Oceanogr., 57(4), 1067-1083, doi:10.4319/lo.2012.57.4.1067, 2012.

Nakagawa, T., Mori, K., Kato, C., Takahashi, R. and Tokuyama, T.: Distribution of cold-adapted ammonia-oxidizing

20 microorganisms in the deep-ocean of the northeastern Japan Sea, Microbes Environ., 22(4), 365-372, doi:10.1264/jsme2.22.365, 2007.

Needoba, J. A., Foster, R. A., Sakamoto, C., Zehr, J. P. and Johnson, K. S.: Nitrogen fixation by unicellular diazotrophic cyanobacteria in the temperate oligotrophic North Pacific Ocean, Limnol. Oceanogr., 52(4), 1317-1327, doi:10.4319/10.2007.52.4.1317, 2007.

25 Neubacher, E. C., Parker, R. E. and Trimmer, M.: The potential effect of sustained hypoxia on nitrogen cycling in sediment from the southern North Sea: A mesocosm experiment, Biogeochemistry, 113(1-3), 69-84, doi:10.1007/s10533-012-9749$5,2013$.

Nicholls, J. and Trimmer, M.: Widespread occurrence of the anammox reaction in estuarine sediments, Aquat. Microb. Ecol., 55, 105-113, doi:10.3354/ame01285, 2009.

30 Norton, J. M., Alzerreca, J. J., Suwa, Y. and Klotz, M. G.: Diversity of ammonia monooxygenase operon in autotrophic ammonia-oxidizing bacteria, Arch. Microbiol., 177(2), 139-149, doi:10.1007/s00203-001-0369-z, 2002.

Nunoura, T., Nishizawa, M., Kikuchi, T., Tsubouchi, T., Hirai, M., Koide, O., Miyazaki, J., Hirayama, H., Koba, K. and Takai, K.: Molecular biological and isotopic biogeochemical prognoses of the nitrification-driven dynamic microbial nitrogen cycle in hadopelagic sediments., Environ. Microbiol., 15(11), 3087-107, doi:10.1111/1462-2920.12152, 2013. 
Biogeosciences Discuss., https://doi.org/10.5194/bg-2018-279

Manuscript under review for journal Biogeosciences

Discussion started: 14 June 2018

(c) Author(s) 2018. CC BY 4.0 License.

Oakley, B. B., Francis, C. A., Roberts, K. J., Fuchsman, C. A., Srinivasan, S. and Staley, J. T.: Analysis of nitrite reductase (nirK and nirS) genes and cultivation reveal depauperate community of denitrifying bacteria in the Black Sea suboxic zone, Environ. Microbiol., 9(1), 118-130, doi:10.1111/j.1462-2920.2006.01121.x, 2007.

Ohmori, M. and Hattori, A.: Effect of ammonia on nitrogen fixation by the blue-green alga Anabaena cylindrica, Plant Cell 5 Physiol., 142(38814), 131-142, 1974.

Olson, N. D. and Lesser, M. P.: Diazotrophic diversity in the Caribbean coral, Montastraea cavernosa, Arch. Microbiol., 195(12), 853-859, doi:10.1007/s00203-013-0937-z, 2013.

Olson, N. D., Ainsworth, T. D., Gates, R. D. and Takabayashi, M.: Diazotrophic bacteria associated with Hawaiian Montipora corals: Diversity and abundance in correlation with symbiotic dinoflagellates, J. Exp. Mar. Bio. Ecol., 371(2),

10 140-146, doi:10.1016/j.jembe.2009.01.012, 2009.

Padilla, C. C., Bristow, L. a, Sarode, N., Garcia-Robledo, E., Gómez Ramírez, E., Benson, C. R., Bourbonnais, A., Altabet, M. A., Girguis, P. R., Thamdrup, B. and Stewart, F. J.: NC10 bacteria in marine oxygen minimum zones, ISME J., 10(8), 2067-2071, doi:10.1038/ismej.2015.262, 2016.

Pajares, S., Merino-Ibarra, M., Macek, M. and Alcocer, J.: Vertical and seasonal distribution of picoplankton and functional

15 nitrogen genes in a high-altitude warm-monomictic tropical lake, Freshw. Biol., 62(7), 1180-1193, doi:10.1111/fwb.12935, 2017.

Papaspyrou, S., Smith, C. J., Dong, L. F., Whitby, C., Dumbrell, A. J. and Nedwell, D. B.: Nitrate reduction functional genes and nitrate reduction potentials persist in deeper estuarine sediments. Why?, PLoS One, 9(4), e94111, doi:10.1371/journal.pone.0094111, 2014.

20 Pedneault, E., Galand, P. E., Potvin, M., Tremblay, J.-É. and Lovejoy, C.: Archaeal amoA and ureC genes and their transcriptional activity in the Arctic Ocean, Sci. Rep., 4(1), 4661, doi:10.1038/srep04661, 2015.

Philippot, L., Piutti, S., Martin-Laurent, F., Hallet, S. and Germon, J. C.: Molecular analysis of the nitrate-reducing community from unplanted and maize-planted soils, Appl. Environ. Microbiol., 68(12), 6121-6128, doi:10.1128/AEM.68.12.6121-6128.2002, 2002

25 Piña-Ochoa, E., Hogslund, S., Geslin, E., Cedhagen, T., Revsbech, N. P., Nielsen, L. P., Schweizer, M., Jorissen, F., Rysgaard, S. and Risgaard-Petersen, N.: Widespread occurrence of nitrate storage and denitrification among Foraminifera and Gromiida, Proc. Natl. Acad. Sci., 107(3), 1148-1153, doi:10.1073/pnas.0908440107, 2010.

Pitcher, A., Wuchter, C., Siedenberg, K., Schouten, S. and Sinninghe Damsté, J. S.: Crenarchaeol tracks winter blooms of ammonia-oxidizing Thaumarchaeota in the coastal North Sea, Limnol. Oceanogr., 56(6), 2308-2318, doi:10.4319/1o.2011.56.6.2308, 2011a.

Pitcher, A., Villanueva, L., Hopmans, E. C., Schouten, S., Reichart, G.-J. and Sinninghe Damsté, J. S.: Niche segregation of ammonia-oxidizing archaea and anammox bacteria in the Arabian Sea oxygen minimum zone, ISME J., 5(12), 1896-1904, doi:10.1038/ismej.2011.60, 2011b.

Pogoreutz, C., Rädecker, N., Cárdenas, A., Gärdes, A., Wild, C. and Voolstra, C. R.: Nitrogen fixation aligns with nifH 
Biogeosciences Discuss., https://doi.org/10.5194/bg-2018-279

Manuscript under review for journal Biogeosciences

Discussion started: 14 June 2018

(c) Author(s) 2018. CC BY 4.0 License.

abundance and expression in two coral trophic functional groups, Front. Microbiol., 8, doi:10.3389/fmicb.2017.01187, 2017.

Preisler, A., de Beer, D., Lichtschlag, A., Lavik, G., Boetius, A. and Jørgensen, B. B.: Biological and chemical sulfide oxidation in a Beggiatoa inhabited marine sediment, ISME J., 1(4), 341-353, doi:10.1038/ismej.2007.50, 2007.

5 Purkhold, U., Pommerening-Roser, A., Juretschko, S., Schmid, M. C., Koops, H.-P. and Wagner, M.: Phylogeny of all recognized species of ammonia oxidizers based on comparative $16 \mathrm{~S}$ rRNA and amoA sequence analysis: implications for molecular diversity surveys, Appl. Environ. Microbiol., 66(12), 5368-5382, doi:10.1128/AEM.66.12.5368-5382.2000, 2000.

Radax, R., Hoffmann, F., Rapp, H. T., Leininger, S. and Schleper, C.: Ammonia-oxidizing archaea as main drivers of

10 nitrification in cold-water sponges, Environ. Microbiol., 14(4), 909-923, doi:10.1111/j.1462-2920.2011.02661.x, 2012.

Raghoebarsing, A. A., Pol, A., van de Pas-Schoonen, K. T., Smolders, A. J. P., Ettwig, K. F., Rijpstra, W. I. C., Schouten, S., Damsté, J. S. S., Op den Camp, H. J. M., Jetten, M. S. M. and Strous, M.: A microbial consortium couples anaerobic methane oxidation to denitrification, Nature, 440(7086), 918-921, doi:10.1038/nature04617, 2006.

Rani, S., Koh, H. W., Rhee, S. K., Fujitani, H. and Park, S. J.: Detection and diversity of the nitrite oxidoreductase alpha

15 subunit (nxrA) gene of Nitrospina in marine sediments, Microb. Ecol., 73(1), 111-122, doi:10.1007/s00248-016-0897-3, 2017.

Rasigraf, O., Schmitt, J., Jetten, M. S. M. M. and Lüke, C.: Metagenomic potential for and diversity of N-cycle driving microorganisms in the Bothnian Sea sediment, Microbiologyopen, 6(4), e00475, doi:10.1002/mbo3.475, 2017.

Ravishankara, A. R., Daniel, J. S. and Portmann, R. W.: Nitrous oxide $\left(\mathrm{N}_{2} \mathrm{O}\right)$ : The dominant ozone-depleting substance

20 emitted in the 21st century, Science, 326(5949), 123-125, doi:10.1126/science.1176985, 2009.

Rees, A. P., Turk-Kubo, K. A., Al-Moosawi, L., Alliouane, S., Gazeau, F., Hogan, M. E. and Zehr, J. P.: Ocean acidification impacts on nitrogen fixation in the coastal western Mediterranean Sea, Estuar. Coast. Shelf Sci., 186, 45-57, doi:10.1016/j.ecss.2016.01.020, 2017.

Reyes, C., Schneider, D., Lipka, M., Thürmer, A., Böttcher, M. E. and Friedrich, M. W.: Nitrogen metabolism genes from

25 temperate marine sediments, Mar. Biotechnol., 19(2), 175-190, doi:10.1007/s10126-017-9741-0, 2017.

Rich, J. J., Dale, O. R., Song, B. and Ward, B. B.: Anaerobic ammonium oxidation (anammox) in Chesapeake Bay sediments, Microb. Ecol., 55(2), 311-320, doi:10.1007/s00248-007-9277-3, 2008.

Risgaard-Petersen, N., Meyer, R., Schmid, M., Jetten, M., Enrich-Prast, A., Rysgaard, S. and Revsbech, N.: Anaerobic ammonium oxidation in an estuarine sediment, Aquat. Microb. Ecol., 36(3), 293-304, doi:10.3354/ame036293, 2004.

30 Risgaard-Petersen, N., Meyer, R. and Revsbech, N.: Denitrification and anaerobic ammonium oxidation in sediments: effects of microphytobenthos and $\mathrm{NO}_{3}{ }^{-}$, Aquat. Microb. Ecol., 40, 67-76, doi:10.3354/ame040067, 2005.

Risgaard-Petersen, N., Langezaal, A. M., Ingvardsen, S., Schmid, M. C., Jetten, M. S. M., Op den Camp, H. J. M., Derksen, J. W. M., Piña-Ochoa, E., Eriksson, S. P., Peter Nielsen, L., Peter Revsbech, N., Cedhagen, T. and van der Zwaan, G. J.: Evidence for complete denitrification in a benthic foraminifer, Nature, 443(7107), 93-96, doi:10.1038/nature05070, 2006. 
Biogeosciences Discuss., https://doi.org/10.5194/bg-2018-279

Manuscript under review for journal Biogeosciences

Discussion started: 14 June 2018

(c) Author(s) 2018. CC BY 4.0 License.

Robertson, E. K., Roberts, K. L., Burdorf, L. D. W., Cook, P. and Thamdrup, B.: Dissimilatory nitrate reduction to ammonium coupled to Fe(II) oxidation in sediments of a periodically hypoxic estuary, Limnol. Oceanogr., 61(1), 365-381, doi:10.1002/lno.10220, 2016.

Rodhe, H.: A comparison of the contribution of various gases to the greenhouse effect, Science, 248(4960), 1217-1219, 5 doi:10.1126/science.248.4960.1217, 1990.

Rotthauwe, J. and Witzel, K.: The ammonia monooxygenase structural gene amoA as a functional marker: molecular finescale analysis of natural ammonia-oxidizing populations, Appl. Environ. Microbiol, 63(12), 4704-4712, 1997.

Rush, D., Wakeham, S. G., Hopmans, E. C., Schouten, S. and Sinninghe Damsté, J. S.: Biomarker evidence for anammox in the oxygen minimum zone of the Eastern Tropical North Pacific, Org. Geochem., 53, 80-87,

10 doi:10.1016/j.orggeochem.2012.02.005, 2012 .

Russ, L., Kartal, B., op den Camp, H. J. M., Sollai, M., Le Bruchec, J., Caprais, J.-C., Godfroy, A., Sinninghe Damsté, J. S. and Jetten, M. S. M.: Presence and diversity of anammox bacteria in cold hydrocarbon-rich seeps and hydrothermal vent sediments of the Guaymas Basin, Front. Microbiol., 4, doi:10.3389/fmicb.2013.00219, 2013.

Rysgaard, S., Glud, R. N., Risgaard-Petersen, N. and Dalsgaard, T.: Denitrification and anammox activity in Arctic marine

15 sediments, Limnol. Oceanogr., 49(5), 1493-1502, doi:10.4319/1o.2004.49.5.1493, 2004.

Santoro, A. E., Boehm, A. B. and Francis, C. A: Denitrifier community composition along a nitrate and salinity gradient in a coastal aquifer, Appl. Environ. Microbiol., 72(3), 2102-2109, doi:10.1128/AEM.72.3.2102-2109.2006, 2006.

Santoro, A. E., Casciotti, K. L. and Francis, C. A.: Activity, abundance and diversity of nitrifying archaea and bacteria in the central California Current, Environ. Microbiol., 12(7), 1989-2006, doi:10.1111/j.1462-2920.2010.02205.x, 2010.

20 Schmid, M. C., Risgaard-Petersen, N., van de Vossenberg, J., Kuypers, M. M. M., Lavik, G., Petersen, J., Hulth, S., Thamdrup, B., Canfield, D., Dalsgaard, T., Rysgaard, S. S., Sejr, M. K., Strous, M., Op Den Camp, H. J. M. and Jetten, M. S. M.: Anaerobic ammonium-oxidizing bacteria in marine environments: widespread occurrence but low diversity, Environ. Microbiol., 9(6), 1476-1484, doi:10.1111/j.1462-2920.2007.01266.x, 2007.

Severin, I., Bentzon-Tilia, M., Moisander, P. H. and Riemann, L.: Nitrogenase expression in estuarine bacterioplankton 25 influenced by organic carbon and availability of oxygen, FEMS Microbiol. Lett., 362(14), fnv105, doi:10.1093/femsle/fnv105, 2015.

Shao, S., Luan, X., Dang, H., Zhou, H., Zhao, Y., Liu, H., Zhang, Y., Dai, L., Ye, Y. and Klotz, M. G.: Deep-sea methane seep sediments in the Okhotsk Sea sustain diverse and abundant anammox bacteria, FEMS Microbiol. Ecol., 87(2), 503516, doi:10.1111/1574-6941.12241, 2014.

30 Shehzad, A., Liu, J., Yu, M., Qismat, S., Liu, J. and Zhang, X.-H.: Diversity, community composition and abundance of anammox bacteria in sediments of the north marginal seas of China, Microbes Environ., 31(2), 111-120, doi:10.1264/jsme2.ME15140, 2016.

Shi, D., Xu, Y., Hopkinson, B. M. and Morel, F. M. M.: Effect of ocean acidification on iron availability to marine phytoplankton, Science, 327(5966), 676-679, doi:10.1126/science.1183517, 2010. 
Biogeosciences Discuss., https://doi.org/10.5194/bg-2018-279

Manuscript under review for journal Biogeosciences

Discussion started: 14 June 2018

(c) Author(s) 2018. CC BY 4.0 License.

Shiozaki, T., Ijichi, M., Kodama, T., Takeda, S. and Furuya, K.: Heterotrophic bacteria as major nitrogen fixers in the euphotic zone of the Indian Ocean, Global Biogeochem. Cycles, 28(10), 1096-1110, doi:10.1002/2014GB004886, 2014.

Shiozaki, T., Ijichi, M., Isobe, K., Hashihama, F., Nakamura, K., Ehama, M., Hayashizaki, K., Takahashi, K., Hamasaki, K. and Furuya, K.: Nitrification and its influence on biogeochemical cycles from the equatorial Pacific to the Arctic Ocean,

5 ISME J., 10(9), 2184-2197, doi:10.1038/ismej.2016.18, 2016.

Short, S. M., Jenkins, B. D. and Zehr, J. P.: Spatial and temporal distribution of two diazotrophic bacteria in the Chesapeake Bay, Appl. Environ. Microbiol., 70(4), 2186-2192, doi:10.1128/AEM.70.4.2186-2192.2004, 2004.

Siboni, N., Ben-Dov, E., Sivan, A. and Kushmaro, A.: Global distribution and diversity of coral-associated archaea and their possible role in the coral holobiont nitrogen cycle, Environ. Microbiol., 10(11), 2979-2990, doi:10.1111/j.1462-

$10 \quad 2920.2008 .01718 . x, 2008$.

Sintes, E., Bergauer, K., De Corte, D., Yokokawa, T. and Herndl, G. J.: Archaeal amoA gene diversity points to distinct biogeography of ammonia-oxidizing Crenarchaeota in the ocean, Environ. Microbiol., 15(5), 1647-1658, doi:10.1111/j.1462-2920.2012.02801.x, 2013

Slobodkina, G. B., Mardanov, A. V., Ravin, N. V., Frolova, A. A., Chernyh, N. A., Bonch-Osmolovskaya, E. A. and

15 Slobodkin, A. I.: Respiratory ammonification of nitrate coupled to anaerobic oxidation of elemental sulfur in deep-sea autotrophic thermophilic bacteria, Front. Microbiol., 8, doi:10.3389/fmicb.2017.00087, 2017.

Smith, C. J., Nedwell, D. B., Dong, L. F. and Osborn, A. M.: Diversity and abundance of nitrate reductase genes (narG and napA), nitrite reductase genes (nirS and $n r f A$ ), and their transcripts in estuarine sediments, Appl. Environ. Microbiol., 73(11), 3612-3622, doi:10.1128/AEM.02894-06, 2007.

20 Smith, C. J., Dong, L. F., Wilson, J., Stott, A., Osborn, A. M. and Nedwell, D. B.: Seasonal variation in denitrification and dissimilatory nitrate reduction to ammonia process rates and corresponding key functional genes along an estuarine nitrate gradient, Front. Microbiol., 6, doi:10.3389/fmicb.2015.00542, 2015.

Smith, J. M., Casciotti, K. L., Chavez, F. P. and Francis, C. A.: Differential contributions of archaeal ammonia oxidizer ecotypes to nitrification in coastal surface waters, ISME J., 8(8), 1704-1714, doi:10.1038/ismej.2014.11, 2014.

25 Smith, J. M., Mosier, A. C. and Francis, C. A.: Spatiotemporal relationships between the abundance, distribution, and potential activities of ammonia-oxidizing and denitrifying microorganisms in intertidal sediments, Microb. Ecol., 69(1), 13-24, doi:10.1007/s00248-014-0450-1, 2015.

Smith, J. M., Damashek, J., Chavez, F. P. and Francis, C. A.: Factors influencing nitrification rates and the abundance and transcriptional activity of ammonia-oxidizing microorganisms in the dark northeast Pacific Ocean, Limnol. Oceanogr., 61(2), 596-609, doi:10.1002/lno.10235, 2016

Sohm, J. A., Webb, E. A. and Capone, D. G.: Emerging patterns of marine nitrogen fixation, Nat. Rev. Microbiol., 9(7), 499-508, doi:10.1038/nrmicro2594, 2011.

Somes, C. J., Landolfi, A., Koeve, W. and Oschlies, A.: Limited impact of atmospheric nitrogen deposition on marine productivity due to biogeochemical feedbacks in a global ocean model, Geophys. Res. Lett., 43(9), 4500-4509, 
Biogeosciences Discuss., https://doi.org/10.5194/bg-2018-279

Manuscript under review for journal Biogeosciences

Discussion started: 14 June 2018

(c) Author(s) 2018. CC BY 4.0 License.

Song, B., Lisa, J. A. and Tobias, C. R.: Linking DNRA community structure and activity in a shallow lagoonal estuarine system, Front. Microbiol., 5, doi:10.3389/fmicb.2014.00460, 2014.

Sonthiphand, P., Hall, M. W. and Neufeld, J. D.: Biogeography of anaerobic ammonia-oxidizing (anammox) bacteria, Front.

5 Microbiol., 5, doi:10.3389/fmicb.2014.00399, 2014.

Stal, L. J.: Is the distribution of nitrogen-fixing cyanobacteria in the oceans related to temperature?, Environ. Microbiol., 11(7), 1632-1645, doi:10.1111/j.1758-2229.2009.00016.x, 2009.

Stief, P., Fuchs-Ocklenburg, S., Kamp, A., Manohar, C.-S., Houbraken, J., Boekhout, T., de Beer, D. and Stoeck, T.: Dissimilatory nitrate reduction by Aspergillus terreus isolated from the seasonal oxygen minimum zone in the Arabian Sea,

10 BMC Microbiol., 14(1), 35, doi:10.1186/1471-2180-14-35, 2014.

Strous, M. and Jetten, M. S. M.: Anaerobic oxidation of methane and ammonium, Annu. Rev. Microbiol., 58(1), 99-117, doi:10.1146/annurev.micro.58.030603.123605, 2004.

Strous, M., Pelletier, E., Mangenot, S., Rattei, T., Lehner, A., Taylor, M. W., Horn, M., Daims, H., Bartol-Mavel, D., Wincker, P., Barbe, V., Fonknechten, N., Vallenet, D., Segurens, B., Schenowitz-Truong, C., Médigue, C., Collingro, A.,

15 Snel, B., Dutilh, B. E., Op den Camp, H. J. M., van der Drift, C., Cirpus, I., van de Pas-Schoonen, K. T., Harhangi, H. R., van Niftrik, L., Schmid, M., Keltjens, J., van de Vossenberg, J., Kartal, B., Meier, H., Frishman, D., Huynen, M. A., Mewes, H.-W., Weissenbach, J., Jetten, M. S. M., Wagner, M. and Le Paslier, D.: Deciphering the evolution and metabolism of an anammox bacterium from a community genome, Nature, 440(7085), 790-794, doi:10.1038/nature04647, 2006.

20 Syakila, A. and Kroeze, C.: The global nitrous oxide budget revisited, Greenh. Gas Meas. Manag., 1(1), 17-26, doi:10.3763/ghgmm.2010.0007, 2011

Takeuchi, J.: Habitat segregation of a functional gene encoding nitrate ammonification in estuarine sediments, Geomicrobiol. J., 23(2), 75-87, doi:10.1080/01490450500533866, 2006.

Tal, Y., Watts, J. E. M. and Schreier, H. J.: Anaerobic ammonia-oxidizing bacteria and related activity in Baltimore Inner

25 Harbor sediment, Appl. Environ. Microbiol., 71(4), 1816-1821, doi:10.1128/AEM.71.4.1816-1821.2005, 2005.

Tamegai, H., Aoki, R., Arakawa, S. and Kato, C.: Molecular analysis of the nitrogen cycle in deep-sea microorganisms from the Nankai Trough: genes for nitrification and denitrification from deep-sea environmental DNA, Extremophiles, 11(2), 269-275, doi:10.1007/s00792-006-0035-0, 2007.

Teixeira, C., Magalhães, C., Joye, S. B. and Bordalo, A. A.: Response of anaerobic ammonium oxidation to inorganic

30 nitrogen fluctuations in temperate estuarine sediments, J. Geophys. Res. Biogeosciences, 121(7), 1829-1839, doi:10.1002/2015JG003287, 2016.

Thompson, A. W., Foster, R. A., Krupke, A., Carter, B. J., Musat, N., Vaulot, D., Kuypers, M. M. M. and Zehr, J. P.: Unicellular cyanobacterium symbiotic with a single-celled eukaryotic alga, Science., 337(6101), 1546-1550, doi:10.1126/science.1222700, 2012. 
Biogeosciences Discuss., https://doi.org/10.5194/bg-2018-279

Manuscript under review for journal Biogeosciences

Discussion started: 14 June 2018

(c) Author(s) 2018. CC BY 4.0 License.

Tiedje, J. M.: Ecology of denitrification and dissimilatory nitrate reduction to ammonium, in Environmental Microbiology of Anaerobes, edited by A. J. B. Zehnder, pp. 179-244, John Wiley \& Sons, N.Y., 1988.

Timmers, P. H. A., Welte, C. U., Koehorst, J. J., Plugge, C. M., Jetten, M. S. M. and Stams, A. J. M.: Reverse methanogenesis and respiration in methanotrophic archaea, Archaea, 2017, 1-22, doi:10.1155/2017/1654237, 2017.

5 Trimmer, M., Nicholls, J. C. and Deflandre, B.: Anaerobic ammonium oxidation measured in sediments along the Thames estuary, United Kingdom, Appl. Environ. Microbiol., 69(11), 6447-6454, doi:10.1128/AEM.69.11.6447-6454-2003, 2003.

Trimmer, M., Nicholls, J. C., Morley, N., Davies, C. A. and Aldridge, J.: Biphasic behavior of anammox regulated by nitrite and nitrate in an estuarine sediment, Appl. Environ. Microbiol., 71(4), 1923-1930, doi:10.1128/AEM.71.4.1923$1930.2005,2005$.

10 Turk, K., Rees, A. P., Zehr, J. P., Pereira, N., Swift, P., Shelley, R., Lohan, M., Woodward, E. M. S. and Gilbert, J.: Nitrogen fixation and nitrogenase (nifH) expression in tropical waters of the eastern North Atlantic, ISME J., 5(7), 1201-1212, doi:10.1038/ismej.2010.205, 2011.

Urakawa, H., Martens-Habbena, W., Huguet, C., de la Torre, J. R., Ingalls, A. E., Devol, A. H. and Stahl, D. A.: Ammonia availability shapes the seasonal distribution and activity of archaeal and bacterial ammonia oxidizers in the Puget Sound

15 Estuary, Limnol. Oceanogr., 59(4), 1321-1335, doi:10.4319/1o.2014.59.4.1321, 2014.

Vaquer-Sunyer, R. and Duarte, C. M.: Thresholds of hypoxia for marine biodiversity, Proc. Natl. Acad. Sci., 105(40), 15452-15457, doi:10.1073/pnas.0803833105, 2008

Vintila, S. and El-Shehawy, R.: Ammonium ions inhibit nitrogen fixation but do not affect heterocyst frequency in the bloom-forming cyanobacterium Nodularia spumigena strain AV1, Microbiology, 153(11), 3704-3712,

20 doi:10.1099/mic.0.2007/007849-0, 2007.

Voss, M., Bange, H. W., Dippner, J. W., Middelburg, J. J., Montoya, J. P. and Ward, B. B.: The marine nitrogen cycle: recent discoveries, uncertainties and the potential relevance of climate change, Philos. Trans. R. Soc. B., 368, 20130121, doi:10.1098/rstb.2013.0121, 2013.

van de Vossenberg, J., Woebken, D., Maalcke, W. J., Wessels, H. J. C. T., Dutilh, B. E., Kartal, B., Janssen-Megens, E. M.,

25 Roeselers, G., Yan, J., Speth, D., Gloerich, J., Geerts, W., van der Biezen, E., Pluk, W., Francoijs, K.-J., Russ, L., Lam, P., Malfatti, S. A., Tringe, S. G., Haaijer, S. C. M., Op den Camp, H. J. M., Stunnenberg, H. G., Amann, R., Kuypers, M. M. M. and Jetten, M. S. M.: The metagenome of the marine anammox bacterium "Candidatus Scalindua profunda" illustrates the versatility of this globally important nitrogen cycle bacterium, Environ. Microbiol., 15(5), 1275-1289, doi:10.1111/j.1462-2920.2012.02774.x, 2013.

30 Wang, J., Shen, L., He, Z., Hu, J., Cai, Z., Zheng, P. and Hu, B.: Spatial and temporal distribution of nitrite-dependent anaerobic methane-oxidizing bacteria in an intertidal zone of the East China Sea, Appl. Microbiol. Biotechnol., 101(21), 8007-8014, doi:10.1007/s00253-017-8521-0, 2017.

Wang, L., Zheng, B., Nan, B. and Hu, P.: Diversity of bacterial community and detection of nirS- and nirK-encoding denitrifying bacteria in sandy intertidal sediments along Laizhou Bay of Bohai Sea, China, Mar. Pollut. Bull., 88(1-2), 
Biogeosciences Discuss., https://doi.org/10.5194/bg-2018-279

Manuscript under review for journal Biogeosciences

Discussion started: 14 June 2018

(c) Author(s) 2018. CC BY 4.0 License.

Ward, B. B.: Nitrification in marine systems, in Nitrogen in the Marine Environment, vol. 44, pp. 199-261, Elsevier., 2008.

Ward, B. B.: Nitrification, in Reference Module in Earth Systems and Environmental Sciences, pp. 1-8, Elsevier., 2013.

Ward, B. B., Tuit, C. B., Jayakumar, A., Rich, J. J., Moffett, J. and Naqvi, S. W. A.: Organic carbon, and not copper,

5 controls denitrification in oxygen minimum zones of the ocean, Deep Sea Res. Part I Oceanogr. Res. Pap., 55(12), 16721683, doi:10.1016/j.dsr.2008.07.005, 2008.

Ward, B. B., Devol, A. H., Rich, J. J., Chang, B. X., Bulow, S. E., Naik, H., Pratihary, A., Jayakumar, A. and Jayakumar, D.: Denitrification as the dominant nitrogen loss process in the Arabian Sea, Nature, 461(7260), 78-81, doi:10.1038/nature08276, 2009.

10 Welsh, A., Chee-Sanford, J. C., Connor, L. M., Löffler, F. E. and Sanford, R. A.: Refined NrfA phylogeny improves PCRbased $n r f A$ gene detection, Appl. Environ. Microbiol., 80(7), 2110-2119, doi:10.1128/AEM.03443-13, 2014.

Wen, Z., Lin, W., Shen, R., Hong, H., Kao, S.-J. and Shi, D.: Nitrogen fixation in two coastal upwelling regions of the Taiwan Strait, Sci. Rep., 7(1), 17601, doi:10.1038/s41598-017-18006-5, 2017.

Wittorf, L., Bonilla-Rosso, G., Jones, C. M., Bäckman, O., Hulth, S. and Hallin, S.: Habitat partitioning of marine benthic

15 denitrifier communities in response to oxygen availability, Environ. Microbiol. Rep., 8(4), 486-492, doi:10.1111/17582229.12393, 2016.

Woebken, D., Lam, P., Kuypers, M. M. M., Naqvi, S. W. A., Kartal, B., Strous, M., Jetten, M. S. M., Fuchs, B. M. and Amann, R.: A microdiversity study of anammox bacteria reveals a novel Candidatus Scalindua phylotype in marine oxygen minimum zones, Environ. Microbiol., 10(11), 3106-3119, doi:10.1111/j.1462-2920.2008.01640.x, 2008.

20 Wu, M. L., Ettwig, K. F., Jetten, M. S. M., Strous, M., Keltjens, J. T. and Niftrik, L. van: A new intra-aerobic metabolism in the nitrite-dependent anaerobic methane-oxidizing bacterium Candidatus "Methylomirabilis oxyfera," Biochem. Soc. Trans., 39(1), 243-248, doi:10.1042/BST0390243, 2011.

Wu, Y., Cao, Y., Wang, C., Wu, M., Aharon, O. and Xu, X.: Microbial community structure and nitrogenase gene diversity of sediment from a deep-sea hydrothermal vent field on the Southwest Indian Ridge, Acta Oceanol. Sin., 33(10), 94-104,

25 doi:10.1007/s13131-014-0544-0, 2014.

Wuchter, C., Abbas, B., Coolen, M. J. L., Herfort, L., van Bleijswijk, J., Timmers, P., Strous, M., Teira, E., Herndl, G. J., Middelburg, J. J., Schouten, S. and Sinninghe Damste, J. S.: Archaeal nitrification in the ocean, Proc. Natl. Acad. Sci., 103(33), 12317-12322, doi:10.1073/pnas.0600756103, 2006.

Xu, W., Li, M., Ding, J.-F., Gu, J.-D. and Luo, Z.-H.: Bacteria dominate the ammonia-oxidizing community in a

30 hydrothermal vent site at the Mid-Atlantic Ridge of the South Atlantic Ocean, Appl. Microbiol. Biotechnol., 98(18), 79938004, doi:10.1007/s00253-014-5833-1, 2014.

Yang, S. and Gruber, N.: The anthropogenic perturbation of the marine nitrogen cycle by atmospheric deposition: Nitrogen cycle feedbacks and the ${ }^{15} \mathrm{~N}$ Haber-Bosch effect, Global Biogeochem. Cycles, 30(10), 1418-1440, doi:10.1002/2016GB005421, 2016. 
Biogeosciences Discuss., https://doi.org/10.5194/bg-2018-279

Manuscript under review for journal Biogeosciences

Discussion started: 14 June 2018

(c) Author(s) 2018. CC BY 4.0 License.

Yang, S., Sun, W., Zhang, F. and Li, Z.: Phylogenetically diverse denitrifying and ammonia-oxidizing bacteria in corals Alcyonium gracillimum and Tubastraea coccinea, Mar. Biotechnol., 15(5), 540-551, doi:10.1007/s10126-013-9503-6, 2013.

Yin, G., Hou, L., Liu, M., Li, X., Zheng, Y., Gao, J., Jiang, X., Wang, R., Yu, C. and Lin, X.: DNRA in intertidal sediments 5 of the Yangtze Estuary, J. Geophys. Res. Biogeosciences, 122(8), 1988-1998, doi:10.1002/2017JG003766, 2017.

Yool, A., Martin, A. P., Fernández, C. and Clark, D. R.: The significance of nitrification for oceanic new production, Nature, 447(7147), 999-1002, doi:10.1038/nature05885, 2007.

Yu, T., Li, M., Niu, M., Fan, X., Liang, W. and Wang, F.: Difference of nitrogen-cycling microbes between shallow bay and deep-sea sediments in the South China Sea, Appl. Microbiol. Biotechnol., 102(1), 447-459, doi:10.1007/s00253-017-8594-

$109,2018$.

Zehr, J. P. and Paerl, H. W.: Molecular ecological aspects of nitrogen fixation in the marine environment, in Microbial Ecology of the Oceans, pp. 481-525, John Wiley \& Sons, Inc., Hoboken, NJ, USA., 2008.

Zehr, J. P., Jenkins, B. D., Short, S. M. and Steward, G. F.: Nitrogenase gene diversity and microbial community structure: a cross-system comparison, Environ. Microbiol., 5(7), 539-554, doi:10.1046/j.1462-2920.2003.00451.x, 2003.

15 Zehr, J. P., Bench, S. R., Carter, B. J., Hewson, I., Niazi, F., Shi, T., Tripp, H. J. and Affourtit, J. P.: Globally distributed uncultivated oceanic $\mathrm{N}_{2}$-fixing cyanobacteria lack oxygenic photosystem II, Science, 322(5904), 1110-1112, doi:10.1126/science.1165340, 2008.

Zhang, F., Pita, L., Erwin, P. M., Abaid, S., López-Legentil, S. and Hill, R. T.: Symbiotic archaea in marine sponges show stability and host specificity in community structure and ammonia oxidation functionality, FEMS Microbiol. Ecol., 90(3), 699-707, doi:10.1111/1574-6941.12427, 2014.

Zhang, M., Luo, Y., Lin, L., Lin, X., Hetharua, B., Zhao, W., Zhou, M., Zhan, Q., Xu, H., Zheng, T. and Tian, Y.: Molecular and stable isotopic evidence for the occurrence of nitrite-dependent anaerobic methane-oxidizing bacteria in the mangrove sediment of Zhangjiang Estuary, China, Appl. Microbiol. Biotechnol., 102(5), 2441-2454, doi:10.1007/s00253-017-8718$2,2018$.

25 Zhang, Y., Xie, X., Jiao, N., Hsiao, S. S. Y. and Kao, S. J.: Diversity and distribution of amoA-type nitrifying and nirS-type denitrifying microbial communities in the Yangtze River estuary, Biogeosciences, 11(8), 2131-2145, doi:10.5194/bg-112131-2014, 2014.

Zheng, Y., Hou, L., Newell, S., Liu, M., Zhou, J., Zhao, H., You, L. and Cheng, X.: Community dynamics and activity of ammonia-oxidizing prokaryotes in intertidal sediments of the Yangtze Estuary, Appl. Environ. Microbiol., 80(1), 408-419, doi:10.1128/AEM.03035-13, 2014.

Zheng, Y., Hou, L., Liu, M., Liu, Z., Li, X., Lin, X., Yin, G., Gao, J., Yu, C., Wang, R. and Jiang, X.: Tidal pumping facilitates dissimilatory nitrate reduction in intertidal marshes, Sci. Rep., 6(1), 21338, doi:10.1038/srep21338, 2016.

Zumft, W. G.: Cell biology and molecular basis of denitrification, Microbiol. Mol. Biol. Rev., 61(4), 533-616, 1997. 
Biogeosciences Discuss., https://doi.org/10.5194/bg-2018-279

Manuscript under review for journal Biogeosciences

Discussion started: 14 June 2018

(c) Author(s) 2018. CC BY 4.0 License.

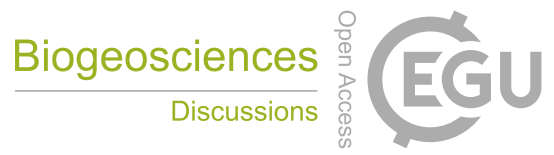

(c) ${ }_{\mathrm{By}}$

5

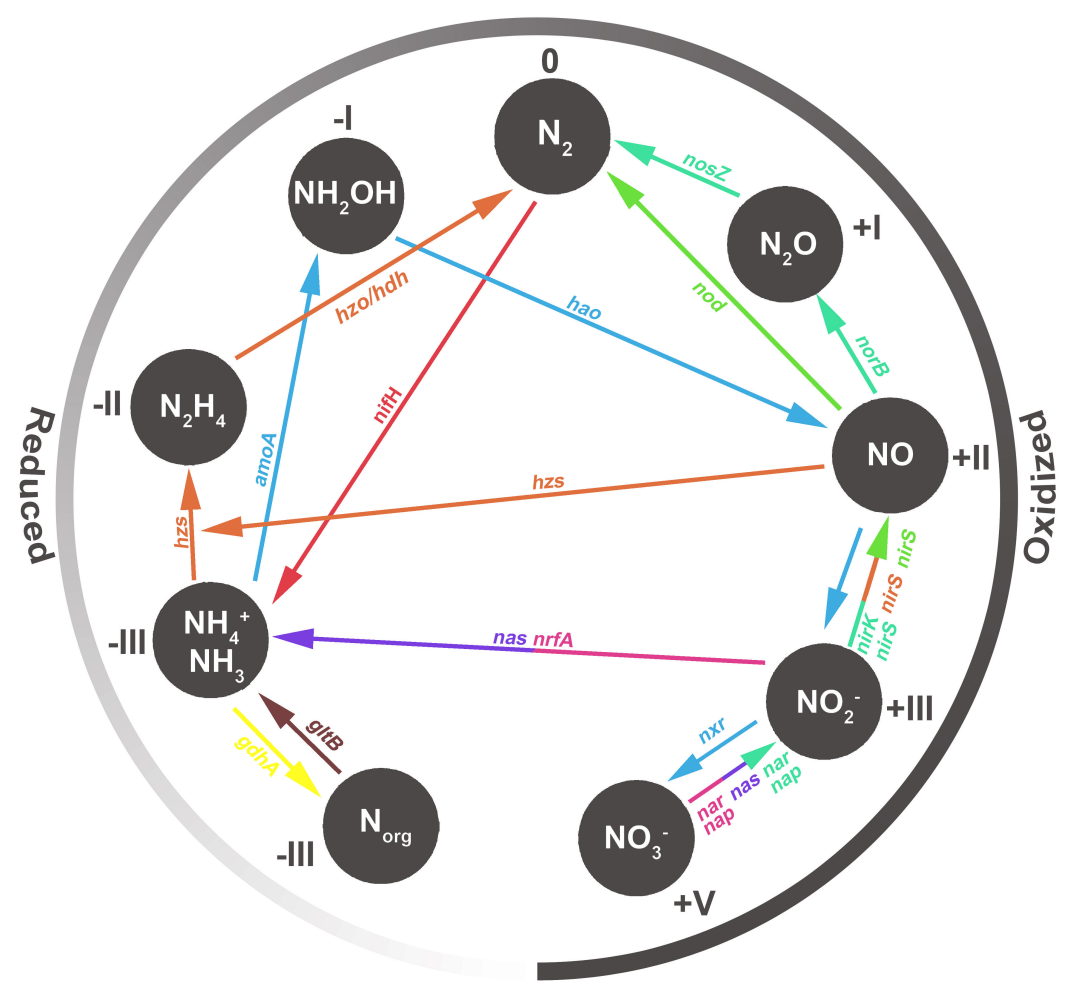

Figure 1: Nitrogen species involved in $\mathrm{N}$ cycling and its transformations. Each grey circle represents a $\mathrm{N}$ species, and the number next to

$(n i f H)$ in red, nitrification ( $a m o A, h a o, n x r)$ in light blue, DNRA (nar, nap, nrfA) in magenta, ANRA (nas) in violet, denitrification (nar, nap, nirK, nirS, nor B, nosZ) in emerald green, $\mathrm{N}$-damo (nod, nirS) in green, anammox (hzs, hdh) in orange, $\mathrm{N}$ assimilation $(g d h A)$ in yellow, and remineralization $(g l t B)$ in brown. 
Biogeosciences Discuss., https://doi.org/10.5194/bg-2018-279

Manuscript under review for journal Biogeosciences

Discussion started: 14 June 2018

(c) Author(s) 2018. CC BY 4.0 License.

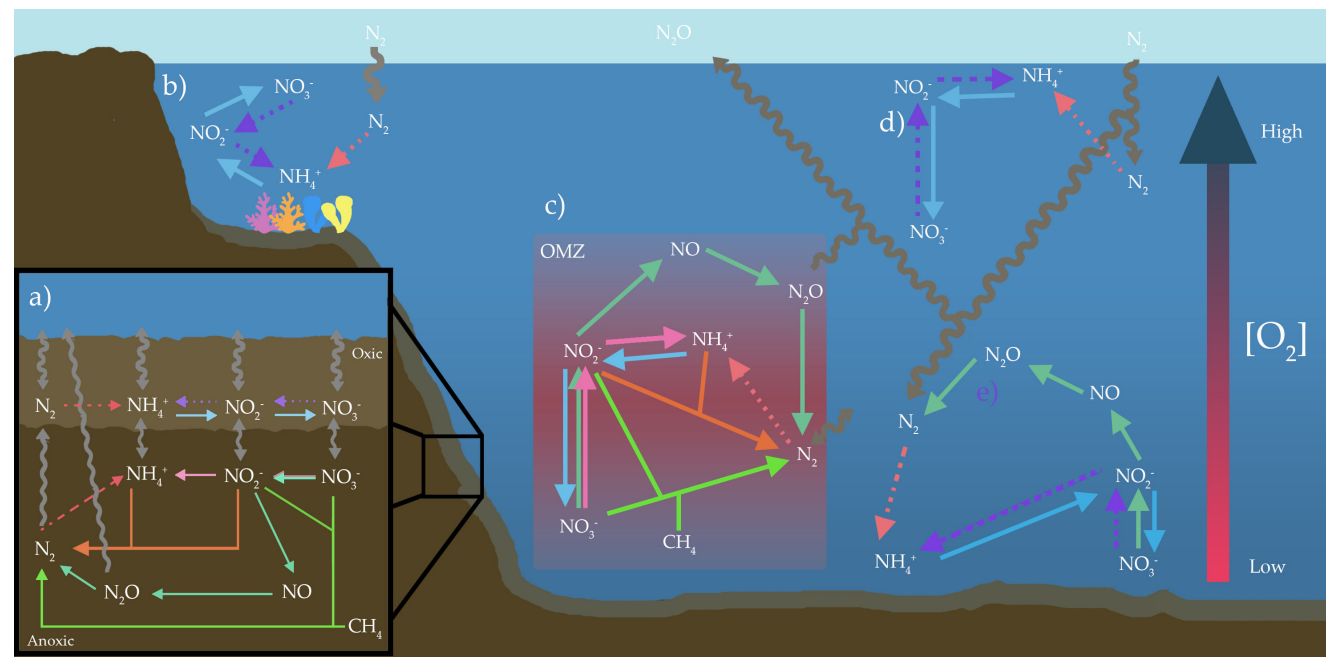

Figure 2. The main studied processes of the $\mathrm{N}$ cycle in different marine environments: a) coastal and deep ocean sediments, b) coral reefs,

c) oxygen minimum zones (OMZs), d) open ocean (with higher oxygen concentrations) and deep ocean (with lower oxygen concentrations). Every colored arrow represents a $\mathrm{N}$ transformation: $\mathrm{N}_{2}$ fixation (red), nitrification (light blue), DNRA (magenta), ANRA (violet), denitrification (emerald green), $\mathrm{N}$-damo (green), and anammox (orange). Continuous arrows represent dissimilatory processes, while dashed arrows represent assimilatory processes. Grey curved arrows represent physical processes such as advection and diffusion. 
Biogeosciences Discuss., https://doi.org/10.5194/bg-2018-279

Manuscript under review for journal Biogeosciences

Discussion started: 14 June 2018

(c) Author(s) 2018. CC BY 4.0 License.

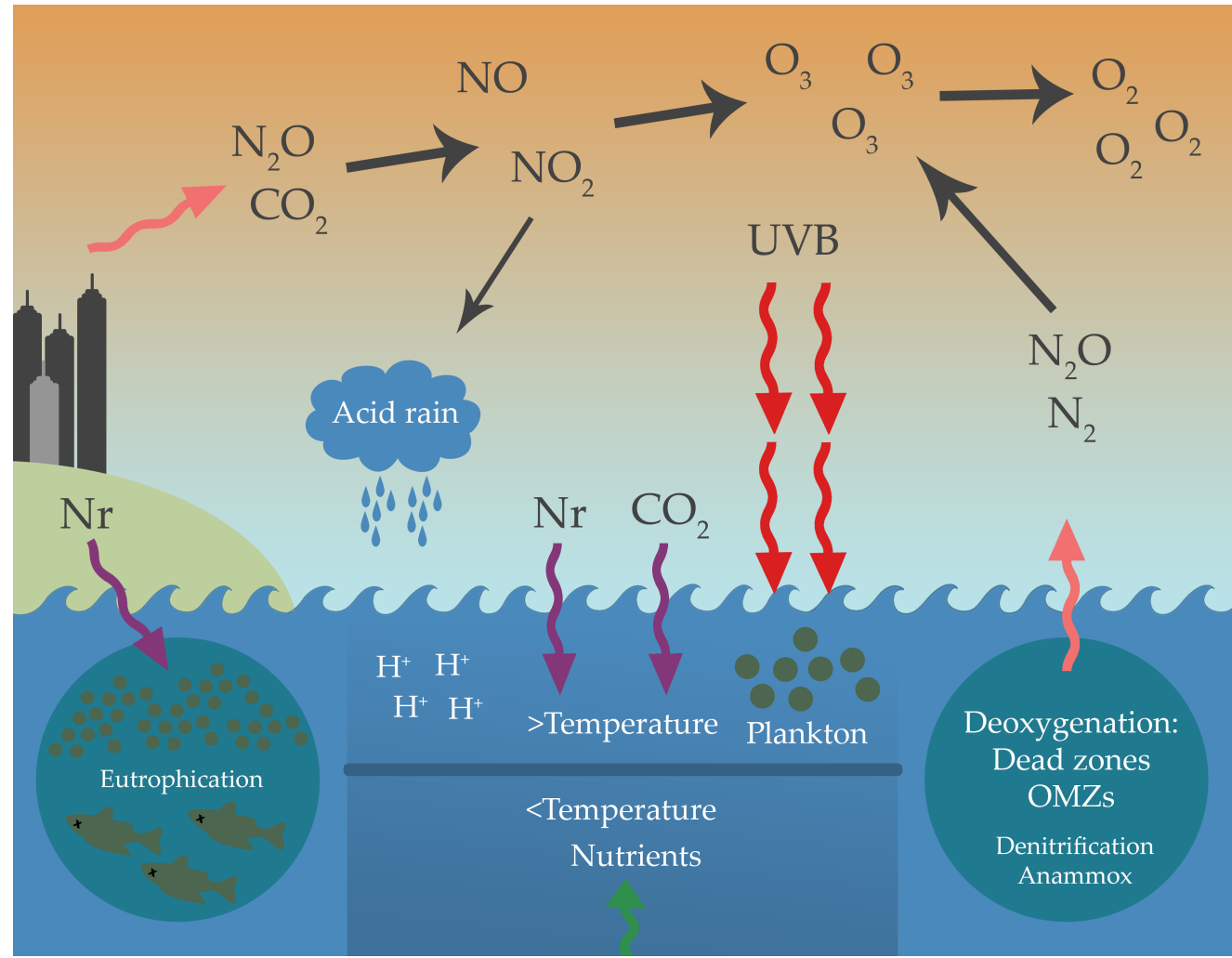

5

Figure 3. Anthropogenic activities and their effects on marine $\mathrm{N}$ cycling. Reactive $\mathrm{N}(\mathrm{Nr})$ is introduced into the marine ecosystems by runoff or atmospheric deposition, causing eutrophication, the formation of dead zones and the expansion of the ocean minimum zones (OMZs). The release of $\mathrm{N}$ oxides $\left(\mathrm{N}_{2} \mathrm{O}, \mathrm{NO}\right)$ from anthropogenic activities and oxygen-depleted zones causes stratospheric ozone depletion leading to higher UVB exposition, which produces the damage of marine life, acid rain and ocean warming. Ocean warming causes water stratification, deoxygenation, and the formation of dead zones. Dead zones and OMZs are hotspots for anammox and denitrification, causing $\mathrm{N}$ loss $\left(\mathrm{N}_{2}\right.$ and $\left.\mathrm{N}_{2} \mathrm{O}\right)$. Elevated atmospheric $\mathrm{CO}_{2}$ acidifies seawater, decreasing pH-dependent $\mathrm{N}$-cycling processes such as nitrification, and enhancing $\mathrm{N}_{2}$ fixation. 